Andrews University

Digital Commons @ Andrews University

2008

\title{
A Model for Small Group Ministry in the North Zambia Field of the Seventh-day Adventist Church
}

Wellington Supuni Chapi

Andrews University

Follow this and additional works at: https://digitalcommons.andrews.edu/dmin

Part of the Practical Theology Commons

\section{Recommended Citation}

Chapi, Wellington Supuni, "A Model for Small Group Ministry in the North Zambia Field of the Seventh-day Adventist Church" (2008). Professional Dissertations DMin. 450.

https://dx.doi.org/10.32597/dmin/450

https://digitalcommons.andrews.edu/dmin/450

This Project Report is brought to you for free and open access by the Graduate Research at Digital Commons @ Andrews University. It has been accepted for inclusion in Professional Dissertations DMin by an authorized administrator of Digital Commons @ Andrews University. For more information, please contact repository@andrews.edu. 


\section{ABSTRACT}

A MODEL FOR SMALL GROUP MINISTRY IN THE NORTH ZAMBIA

FIELD OF THE SEVENTH-DAY ADVENTIST CHURCH

by

Wellington S. Chapi

Adviser: Gorden R. Doss 


\section{ABSTRACT OF GRADUATE STUDENT RESEARCH \\ Dissertation}

Andrews University

Seventh-day Adventist Church

Title: A MODEL FOR SMALL GROUP MINISTRY IN THE NORTH ZAMBIA FIELD OF THE SEVENTH-DAY ADVENTIST CHURCH

Name of researcher: Wellington S. Chapi

Name and degree of faculty advisor: Gorden R. Doss, D.Min., Ph.D.

Date completed: July 2008

\section{Purpose}

The purpose of this dissertation is to develop a contextualized model for small group ministry in the North Zambia Field to enhance the retention of new members..

\section{Statement of Problem}

While the numbers of members being baptized annually are encouraging indeed, the percentage of members dropping out of the church annually is a cause of great concern. Between 1996 and 2006, the North Zambia Field, through baptism or profession of faith, had 72,652 converts, an annual average of 7,265 converts. However, 17,303 or 23.82 percent of those added and 2.70 percent of the total membership dropped out of the 
church through apostasy and going missing. ${ }^{1}$ This annual loss of church membership poses a serious problem for church growth. The largest number of members dropping out of the church in the North Zambia Field consists of newly baptized members brought into the church through various evangelistic activities. Many of these members coming into the church are unchurched or from different denominations in Zambia. When these new believers come into the Seventh-day Adventist church from such varying backgrounds, there is a great need for spiritual nurturing, training for discipleship, and pastoral care as they bond with established church members and develop a sense of belonging in their local church families. However, because so many people are baptized at short evangelistic efforts, without first being grounded in the practices and doctrines of the Seventh-day Adventist Church, many new members either return to a life without faith or return to their previous churches. Some of the reasons they give for dropping out of the Seventh-day Adventist Church include: lack of spiritual nurture, lack of discipleship training and lack of pastoral care to help them build relationships and bond with established church members. One way to address this problem is to encourage churches to form small groups to spiritually nurture, train for discipleship, and provide pastoral care to help new members to assimilate.

\section{Methodology}

The resources used in doing this research come from the James White Library at Andrews University in Berrien Springs, Michigan. Other sources also include the Bible, the writings of Ellen G. White, certain officials of the North Zambia Field Office, and the

'Seventh-day Adventist Church Website: North Zambia Field, http://www .adventiststatistics.org/view (accessed February 24, 2006). 
General Conference of the Seventh-day Adventist Church website statistics for the Zambia Union Conference. In view of the fact that the researcher lived in the United States of America from 2003-2008, some of the research data was obtained by telephone interviews with people living in Zambia at the time. The interviews attempted to find out why the new members drop out of the church in the North Zambia Field-especially members who come into the church through evangelistic efforts. Research data was also collected from North Zambia Field departmental directors' records such as the Secretary's Quarterly Report. A questionnaire was mailed to district pastors in the North Zambia Field to discover the reasons why new members drop out of church. These data were integrated with the researcher's first-hand experiences as president of the North Zambia Field from 2000-2002, and several years of experience as the Zambia Union ministerial secretary responsible for church growth.

\section{Expectations from the Project}

This researcher expects to start implementing the small group model for membership retention upon his return to Zambia in 2008. By God's grace, he expects to see positive results as the model is implemented. 
Andrews University

Seventh-day Adventist Theological Seminary

\title{
A MODEL FOR SMALL GROUP MINISTRY IN THE NORTH ZAMBIA FIELD OF THE SEVENTH-DAY ADVENTIST CHURCH
}

\author{
A Dissertation \\ Presented in Partial Fulfillment \\ of the Requirements for the Degree \\ Doctor of Ministry
}

by

Wellington S. Chapi

July 2008 
C Copyright by Wellington S. Chapi 2008

All Rights Reserved 

A MODEL FOR SMALL GROUP MINISTRY IN THE NORTH ZAMBIA

FIELD OF THE SEVENTH-DAY ADVENTIST CHURCH

A dissertation

presented in partial fulfillment

of the requirements for the degree

Doctor of Ministry

by

Wellington S. Chapi

APPROVAL BY THE COMMITTEE:

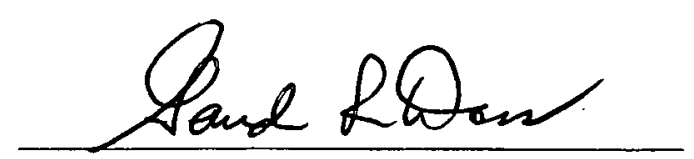

Adviser,

Gorden R. Doss
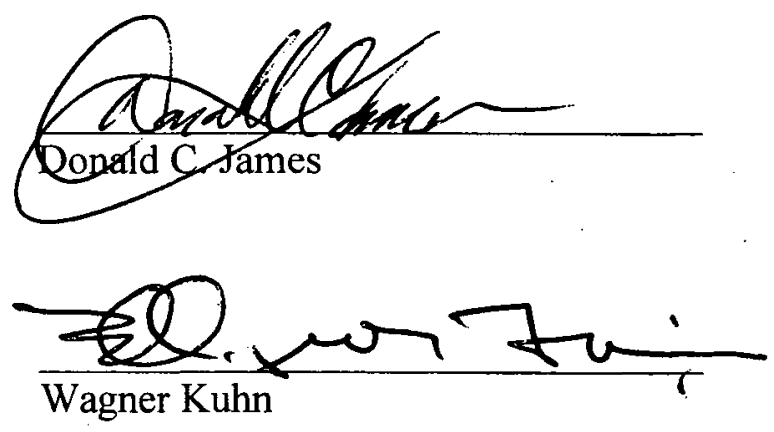

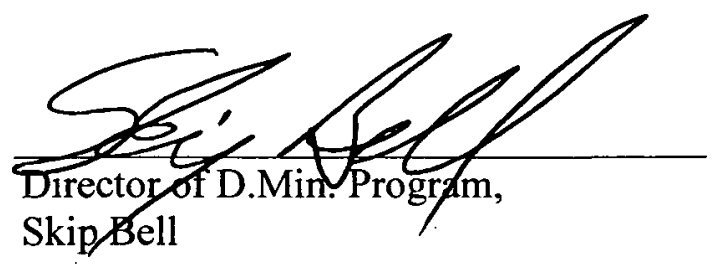

Denis Fortin

Dean, SDA Theological Seminary,

Denis Fortin

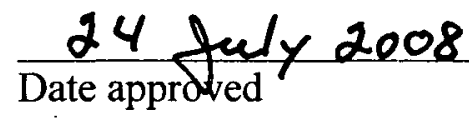




\section{Dedication}

This dissertation is dedicated to my wife, Felistus, and my children namely, Judith, Joseph, Benjamin, Betty, Lukwesa, and Chabu, for their support and encouragement in seeing that I complete my research on time. They were a great source of strength in times of sourcing materials and remembering the names of ministers in the North Zambia Field. When times were hard, they bore with me and were a source of inspiration to me. 


\section{TABLE OF CONTENTS}

LIST OF TABLES $\ldots \ldots \ldots \ldots \ldots \ldots \ldots \ldots \ldots \ldots \ldots \ldots \ldots \ldots \ldots \ldots \ldots \ldots$

ACKNOWLEDGMENTS $\ldots \ldots \ldots \ldots \ldots \ldots \ldots \ldots \ldots \ldots \ldots \ldots \ldots \ldots$

Chapter

1. INTRODUCTION $\ldots \ldots \ldots \ldots \ldots \ldots \ldots \ldots \ldots \ldots \ldots \ldots \ldots \ldots$

Statement of the Problem $\ldots \ldots \ldots \ldots \ldots \ldots \ldots \ldots \ldots \ldots \ldots$

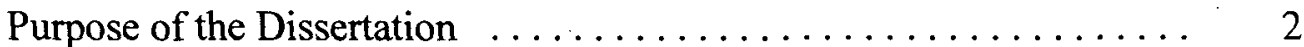

Justification of the Dissertation $\ldots \ldots \ldots \ldots \ldots \ldots \ldots \ldots \ldots \ldots \ldots$

Description of the Study $\ldots \ldots \ldots \ldots \ldots \ldots \ldots \ldots \ldots \ldots \ldots$

Limitation of the Dissertation $\ldots \ldots \ldots \ldots \ldots \ldots \ldots$

2. THEOLOGICAL FOUNDATIONS FOR SMALL GROUP MINISTRY $\ldots \ldots \ldots \ldots \ldots \ldots \ldots \ldots \ldots \ldots \ldots \ldots \ldots \ldots \ldots \ldots \ldots \ldots \ldots, 6$

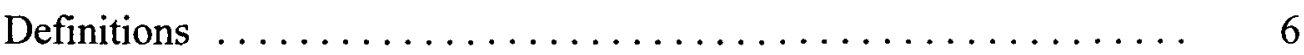

Small Groups in the Old Testament $\ldots \ldots \ldots \ldots \ldots \ldots \ldots \ldots$

The Triune Godhead $\ldots \ldots \ldots \ldots \ldots \ldots \ldots \ldots \ldots \ldots \ldots$

Israel as a Nation $\ldots \ldots \ldots \ldots \ldots \ldots \ldots \ldots \ldots \ldots \ldots \ldots \ldots$

Small Groups in the New Testament ................. 11

Small Groups in the Apostolic Church $\ldots \ldots \ldots \ldots \ldots . \ldots \ldots$

Small Group Communities in Church History $\ldots \ldots \ldots \ldots \ldots$

Ancient and Secular Small Groups Organization $\ldots \ldots \ldots \ldots \ldots$

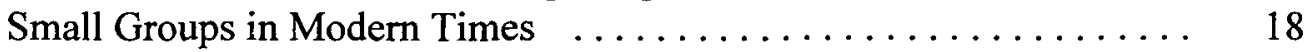

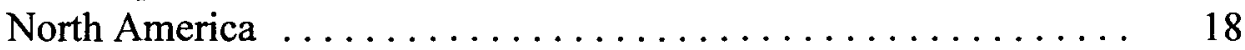

South America $\ldots \ldots \ldots \ldots \ldots \ldots \ldots \ldots \ldots \ldots \ldots \ldots \ldots \ldots$

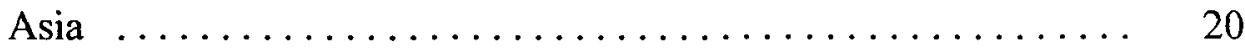

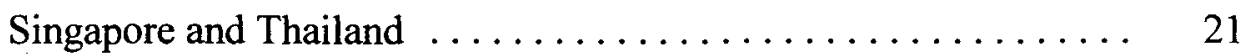

China and Hong Kong $\ldots \ldots \ldots \ldots . \ldots \ldots \ldots . \ldots \ldots$

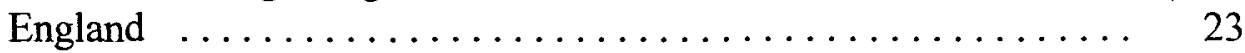

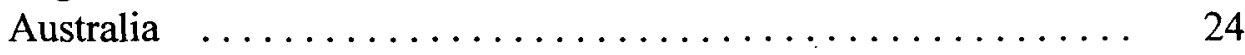

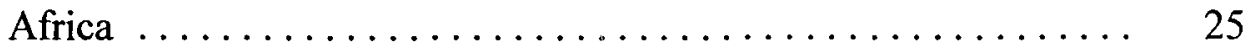

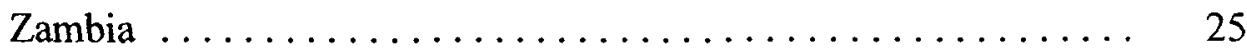

Small Groups in the Writings of Ellen G. White $\ldots \ldots \ldots \ldots \ldots$ 
Small Groups as the Basis for Christian Effort $\ldots \ldots \ldots \ldots \ldots 26$

Counsels to Churches ........................ 27

Small Groups in General Literature $\ldots \ldots \ldots \ldots \ldots \ldots \ldots \ldots . \quad 30$

Different Varieties of Small Groups $\ldots \ldots \ldots \ldots \ldots \ldots \ldots . \quad 30$

Functions of Small Groups $\ldots \ldots \ldots \ldots \ldots \ldots \ldots \ldots . \quad 31$

Why Small Groups are Important Today $\ldots \ldots \ldots \ldots \ldots \ldots \ldots . \quad 39$

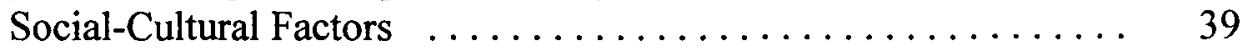

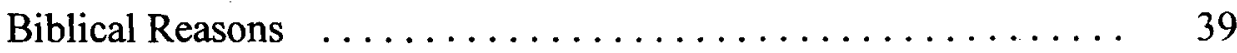

Theological Reasons ....................... $\quad 40$

Small Groups Build Community $\ldots \ldots \ldots \ldots \ldots \ldots \ldots \ldots$. 41

Practical Value of Small Groups $\ldots \ldots \ldots \ldots \ldots \ldots \ldots \ldots, 41$

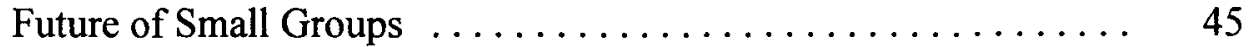

Summary $\ldots \ldots \ldots \ldots \ldots \ldots \ldots \ldots \ldots \ldots \ldots \ldots, \quad 46$

3. THEORETICAL FOUNDATIONS OF SMALL GROUP

MINISTRY .................................. 47

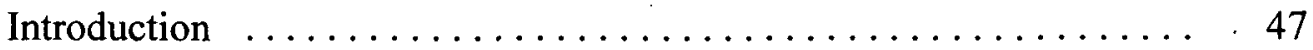

A Brief Survey of Current Literature in Psychology

of Small Groups $\ldots \ldots \ldots \ldots \ldots \ldots \ldots \ldots \ldots \ldots \ldots \ldots \ldots$

A Brief Survey of Current Literature in Sociology of Small Groups .......................... 5

A Brief Survey of Current Literature in Anthropology of Small Groups ............................ 60

A Brief Survey of Current Literature in Education of Small Groups .......................... 65

Why Small Groups Work in Psychology, Sociology, Anthropology, and Education $\ldots \ldots \ldots \ldots \ldots \ldots \ldots \ldots$

4. CHURCH GROWTH PATTERNS IN THE NORTH ZAMBIA FIELD

A Brief History of the North Zambia Field $\ldots \ldots \ldots \ldots \ldots \ldots .78$

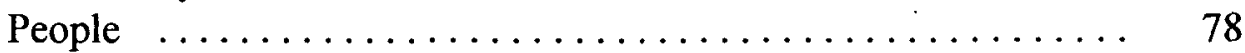

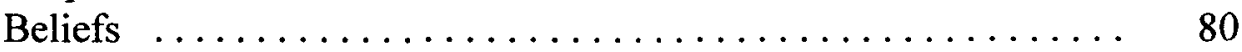

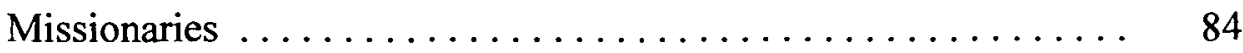

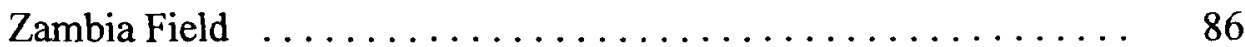

Musofu Mission--1917 ....................... 88

Chimpempe Mission--1919 ................... 88

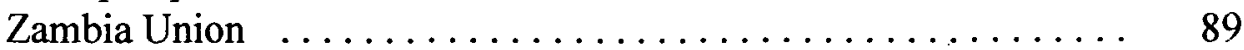

North Zambia Field 1972--Present $\ldots \ldots \ldots \ldots \ldots \ldots \ldots . . \ldots 1$

Evangelistic Methods for Church Growth $\ldots \ldots \ldots \ldots \ldots \ldots \ldots .92$

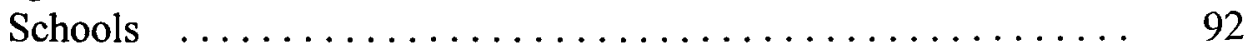


Health Centers ............................. 94

Teachers and Lay Evangelists $\ldots \ldots \ldots \ldots \ldots \ldots \ldots \ldots \ldots \ldots$

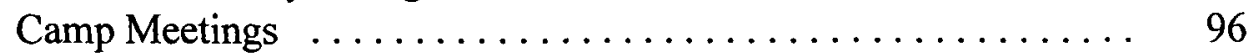

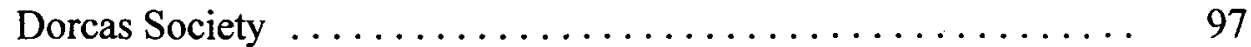

Pastoral Public Evangelism .................... $\quad 99$

Voice of Prophecy Bible School $\ldots \ldots \ldots \ldots \ldots \ldots \ldots \ldots . \ldots 9$

Literature Evangelists ...................... 100

The Problem of Membership Loss $\ldots \ldots \ldots \ldots \ldots \ldots \ldots . \ldots \ldots$

The Scale of Membership Loss $\ldots \ldots \ldots \ldots \ldots \ldots \ldots \ldots .102$

Reasons Why People Leave the Church $\ldots \ldots \ldots \ldots \ldots \ldots \ldots .107$

Eleven Factors Within the Church for Membership

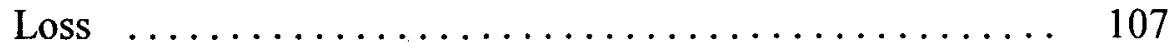

The Factor of Jealousy ................... 107

Lack of Training and Equipping Opportunities ........ 108

Lack of Felt Needs Seminars for New Believers ........ 108

Sabbath Afternoon Activities Focused on Older

Members ............................ 109

Lack of Bonding with New Believers $\ldots \ldots \ldots \ldots \ldots \ldots .109$

Policing Rather than Teaching Church Standards ....... 110

Lack of Mentors ...................... 110

Ministry Opportunities Not Based on Spiritual Gifts . ..... 111

Exclusive Family Leadership ................ 111

Lack of Preparation for Discipling Before Baptism ...... 112

Older Members Lacking Evangelistic Zeal $\ldots \ldots \ldots \ldots \ldots, 112$

Factors of Specific Districts . . . . . . . . . . . . . . . 112

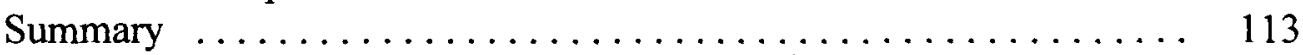

Personal Reasons for Dropping Out $\ldots \ldots \ldots \ldots \ldots \ldots \ldots \ldots . \ldots \ldots$

Idolatry, Blasphemy, and Profanity $\ldots \ldots \ldots \ldots \ldots \ldots \ldots$

Gambling, Domestic Violence, Dishonoring Parents,

Sabbath Breaking, Adultery, Fornication, Homosexual

Practice, Incest, Sexual Abuse of Children and

Vulnerable Adults

Remarriage on Unbiblical Grounds, Physical Violence or

Murder, Fraud or Misrepresentation in Business, Falsehood,

Coveting, Envy, Non-attendance of Church, Persistent

Refusal to Recognize Properly Constituted Church

Authority or Submit to the Order and Discipline of Church ..

Adhering to or Taking Part in a Decisive Disloyal

Movement or Organization, Disorderly Conduct That

Brings Reproach Upon the Church, Use or

Manufacture or Sale of Narcotic Drugs, Use or

Manufacture of Tobacco 
Use, Manufacture, or Sale of Alcoholic Beverages, and Witchcraft or Participation in Non-Christian Traditional Practices

Ranking the Personal Reasons for Members . . . . . . . . . 116

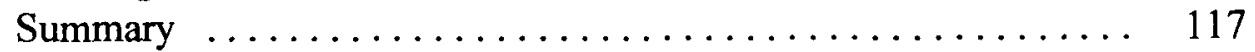

Activities to Enhance Retention, Assimilation, and

Discipling of New Converts . . . . . . . . . . . . . . . 117

Activity 1. A Warm Welcome for New Believers . . . . . . . 118

Activity 2. Fellowship Dinners $\ldots \ldots \ldots \ldots \ldots \ldots \ldots \ldots \ldots \ldots$

Activity 3. Baptismal Gifts $\ldots \ldots \ldots \ldots \ldots \ldots \ldots \ldots \ldots \ldots$

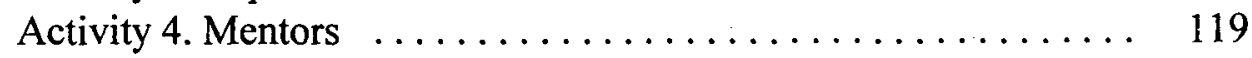

Activity 5. New Believer Classes $\ldots \ldots \ldots \ldots \ldots \ldots \ldots \ldots \ldots$

Activity 6. Meeting Felt Needs ................. 120

Activity 7. Small Group Discussions with Elders .......... 121

Activity 8. Individual Counseling ............... 121

Activity 9. Training and Equipping in Outreach Programs . . . . . 121

Activity 10. Marriage Enrichment Seminars ... . . . . . . . . 122

Activity 11. Free Vegetarian Cooking Classes . . . . . . . . . 122

Activity 12. Church Members Open Their Homes .......... 123

Activity 13. Assistance in Overcoming Sabbath-Related

Unemployment . . . . . . . . . . . . . . . . 123

Activity 14. Adventist Businesses Hire New Believers . . . . . . 124

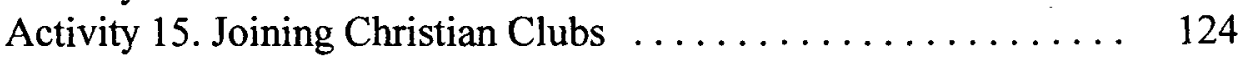

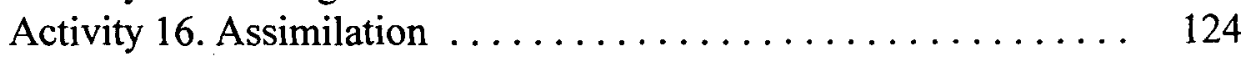

Activity 17. Invitation to Join a Small Group . . . . . . . . . 125

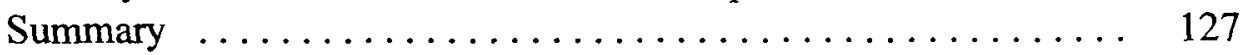

Activities for Spiritual Nurturing of New Converts . . . . . . . . 127

Activity 1. Topical Bible Studies $\ldots \ldots \ldots \ldots \ldots \ldots \ldots \ldots \ldots$

Activity 2. Free Stop Smoking Programs $\ldots \ldots \ldots \ldots \ldots \ldots$

Activity 3. Family Life Programs $\ldots \ldots \ldots \ldots \ldots \ldots \ldots \ldots \ldots$

Activity 4. Prayer Meetings ... . . . . . . . . . . . . . . . 129

Activity 5. Regular Home Visitation . . . . . . . . . . . . . 129

Activity 6. Grief Recovery Support Groups . . . . . . . . . . . . 129

Activity 7. Voice of Prophecy Bible Courses $\ldots \ldots \ldots \ldots$. . . . 130

Activity 8. Special Camp Meeting Programs $\ldots \ldots \ldots \ldots \ldots . \ldots 130$

Activity 9. Youth Training Programs $\ldots \ldots \ldots \ldots \ldots \ldots \ldots \ldots$

Activity 10. Personal Testimonies ................ 131

Activity 11. Instruction in Christian Living $\ldots \ldots \ldots \ldots \ldots \ldots . \ldots 132$

Activity 12. Opportunities for Public Speaking $\ldots \ldots \ldots \ldots \ldots . \ldots 132$

Activity 13. Christian Witnessing Program ............. 132

Activity 14. Church Libraries and Resource Centers ........ 133

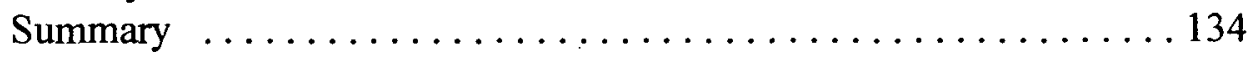


Existing Small Group Ministries in Zambia $\ldots \ldots \ldots \ldots \ldots \ldots . . \ldots \ldots$

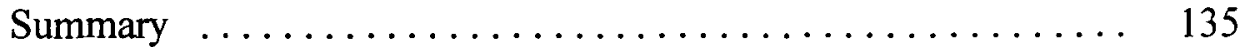

Existing Small Groups in the North Zambia Field ........ 137

Identifying the Main Inadequacies $\ldots \ldots \ldots \ldots \ldots \ldots \ldots \ldots . \ldots \ldots$

Advantages of Small Groups for Building Long-Lasting

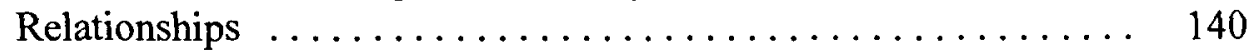

Summary $\ldots \ldots \ldots \ldots \ldots \ldots \ldots \ldots \ldots \ldots \ldots \ldots \ldots \ldots \ldots \ldots, 146$

5. A SMALL GROUP MODEL FOR MEMBERSHIP RETENTION

IN THE NORTH ZAMBIA FIELD $\ldots \ldots \ldots \ldots \ldots \ldots \ldots \ldots \ldots .6 \ldots \ldots$

Small Groups in the General Zambian Context $\ldots \ldots \ldots \ldots \ldots \ldots .148$

Small Groups in the Zambian Church .................. 149

Existing Small Groups in the North Zambia Field

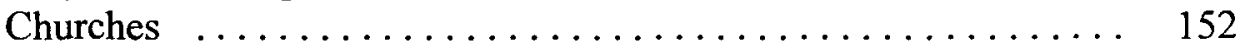

The New Small Groups Model $\ldots \ldots \ldots \ldots \ldots \ldots \ldots \ldots . \ldots \ldots$

Preparation and Training of the Church $\ldots \ldots \ldots \ldots \ldots \ldots \ldots .156$

Pilot Small Groups Formed in Churches in the North Zambia Field ............................ 157

The Structure and Organization of Small Group Ministry $\ldots \ldots \ldots .159$

Purposes of Small Groups ....................... 159

Developing Small Groups for Assimilation $\ldots \ldots \ldots \ldots \ldots \ldots \quad 160$

Developing Small Groups for Spiritual Nurture $\ldots \ldots \ldots \ldots \ldots 168$

Developing Small Groups for Service .............. 174

Developing Small Groups for Training in Discipleship ...... 186

Developing Small Groups for Adjunct Pastoral Care ........ 191

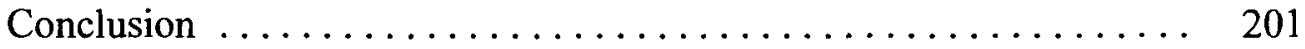

6. SUMMARY, CONCLUSION, AND RECOMMENDATIONS $\ldots \ldots \ldots 202$

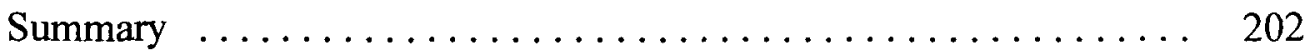

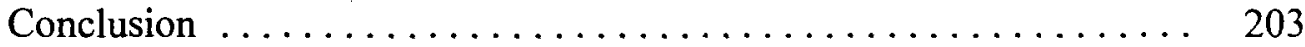

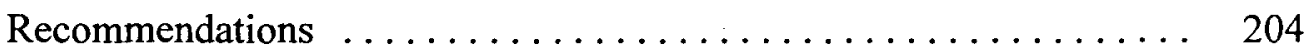

Recommendations for North Zambia Field Districts ....... 205

Recommendations for Churches ................. 205

Appendix

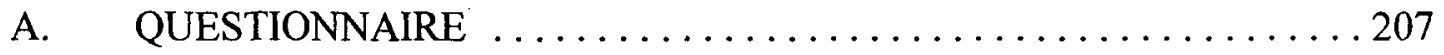

B. SMALL GROUP LEADER'S JOB DESCRIPTION $\ldots \ldots \ldots \ldots .217$ 
C. SMALL GROUP LEADER'S MONTHLY REPORT AND

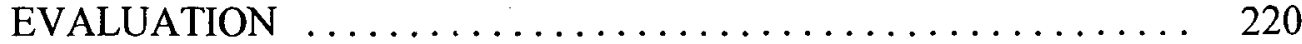

D. SEVEN LESSON OUTLINES FOR SMALL GROUP

SEMINAR ........................... 222

E. ORGANIZATIONAL CHART $\ldots \ldots \ldots \ldots \ldots \ldots \ldots \ldots \ldots \ldots \ldots \ldots \ldots$

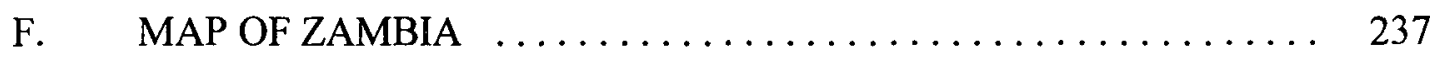

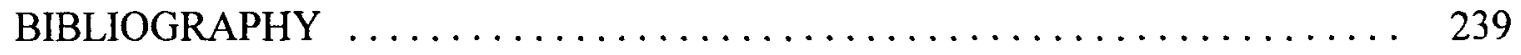

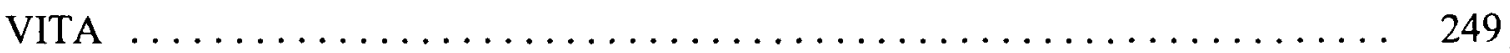




\section{LIST OF TABLES}

1. North Zambia Field Statistical Report Fourth Quarter $2006 \quad \ldots \ldots \ldots$. . . 90

2. North Zambia Field Membership Addition and Attrition $1996-2006$.................................... 104

3. Factors of Poor Member Retention $\ldots \ldots \ldots \ldots \ldots \ldots \ldots \ldots \ldots \ldots \ldots$

4. Retention, Assimilation, and Discipling of New Converts $\ldots \ldots \ldots \ldots 126$

5. Activities for Spiritual Nurturing of New Converts $\ldots \ldots \ldots \ldots \ldots .134$

6. Small Groups in Churches in $2005 \ldots \ldots \ldots \ldots \ldots \ldots \ldots \ldots \ldots \ldots \ldots \ldots \ldots$

7. Types of Small Groups in the North Zambia Field $\ldots \ldots \ldots \ldots \ldots \ldots$ 


\section{ACKNOWLEDGMENTS}

I wish to acknowledge my thanks to God almighty for giving me good health, protection, and guidance during the entire course of my study at Andrews University. All the praise and glory should be attributed to Him for His watchful care and wisdom. I came to Andrews University to sharpen my tools in order to serve Him better. I praise Him for making my dream come true.

I also would like to acknowledge my parents, Mr. John S. Mulumbu and Mrs. Wambalile Mulumbu (deceased), who were my mentors in the formative years of my childhood. They are the ones who led me in the path of righteousness where they were walking as my father served as an head elder for many years at Lwela Mission Church, of the Christian Missions in Many Lands Church. They were the ones who practically demonstrated to me the beauty of serving the Lord. Later in life I joined the ministry voluntarily in my adulthood because of their influence and good example. May their souls rest in peace as they await for the second resurrection.

I acknowledge my son for sponsoring me to Andrews University. Mr. Benjamin Chapi was the one who, while at Cambridge University in the United Kingdom, called me by telephone to tell me that he had made payments and accommodation arrangements for me and my family to go to Andrews University to continue my studies in 2001. At that time, I held a Masters degree in Religion from Andrews' University at Helderberg College 
in South Africa. Later in 2002 my wife and four children arrived on the campus of Andrews University. I thank you my son for your sacrifices that made it possible for me to continue my studies at the Seminary.

I would like to acknowledge my advisors, Dr. Gorden R. Doss, Dr. Donald C. James, and Dr. Wagner Kuhn. Dr. Doss, as my advisor, did a wonderful job in this area. He was patient with me and guided me in the writing and the content of my dissertation from beginning to end. He saw me improve in my writing skills to reach an acceptable standard. I thank you for your specialty and skillfulness in your work. Dr. James, as my second reader, also did a lot to make my dissertation meet the standard and express the small group language as he is an expert in the area of small groups. Dr. Wagner, as my third reader, did the same and the Director of the Doctor of Ministry Program, Dr. Skip Bell, who guided me in intensive courses I took under his feet, the choosing of the relevant topics, and in the content of the dissertation. I am grateful for the work that my advisors did for me.

I wish to acknowledge the wonderful work done by Mrs. Bauer, Bonnie Beres, Dr. Janette Bryson, and Joan Bachelor for correcting my grammar and style. I thank them for making the dissertation meet the Andrews Standard of Written Work. You all deserve my sincere appreciation for your wonderful work. Finally, but not the least, I wish to express my thanks to the then North Zambia Field officers and district pastors for providing information from their churches and participating in the research. The wonderful work you did in the North Zambia Field will go a long way in retention of new members in churches, and in strengthening the small groups as a model for mission. 


\section{CHAPTER 1}

\section{INTRODUCTION}

This dissertation addresses the challenge of member nurture and retention in the North Zambia Field of the Seventh-day Adventist Church. A model of a small group ministry is proposed as a partial solution to the challenge of membership retention.

\section{Statement of the Problem}

While the numbers of members being baptized annually are encouraging indeed, the percentage of members dropping out of the church annually is a cause of great concern. Between 1996 and 2006, 72,652 converts were added through baptism or profession of faith, an annual average of 7,265 converts. However, 17,304 (23.82 percent of those added) or 2.70 percent of the total membership, dropped out of the church through apostasy and going missing.'

While the number of people being baptized annually is encouraging, the number of people leaving the church is alarming. The annual losses pose a serious problem that needs the immediate attention of the North Zambia Field and her churches. From my observation, most members who drop out entered the church through public evangelistic

'Seventh-day Adventist Church Website: North Zambia Field, http://www .adventiststatistics.org/view (accessed February 24, 2006). 
efforts, often conducted by foreign evangelists. Many of these people who come into the church are unchurched people or from various other denominations, such as Roman Catholics, Jehovah's Witnesses, and from various Pentecostal Churches in Zambia. Unfortunately, because many people are baptized at short evangelistic efforts without being well grounded in the doctrines and practices of the Seventh-day Adventist Church, many go back to their former churches or apostatize. They leave the church complaining about lack of bonding (assimilation), spiritual nurture, discipleship training, and pastoral care. The annual numbers of people leaving the church and their complaints about the church pose serious problems that need the immediate attention of the North Zambia Field administration and churches. These problems can be addressed in many ways. One place to begin is by encouraging local churches to form small groups to provide assimilation, spiritual nurture, discipleship training, and pastoral care.

\section{Purpose of the Dissertation}

The purpose of this dissertation is to develop a contextualized model of small group ministry in the North Zambia Field to enhance the retention of new members.

\section{Justification of the Dissertation}

The dissertation is justified because the problem it addresses needs the immediate attention of the North Zambia Field churches. If the problem is not resolved, the mission of the Seventh-day Adventist Church will be hindered in the North Zambia Field. At present, leaders are urgently seeking for solutions to these difficult and complicated problems. Pastors in the districts, various church committees, and North Zambia Field 
Committee are all working together to solve this great problem. The Zambia Union Conference Committee (the higher organization in Zambia) is anxiously looking to the North Zambia Field administration to resolve this dilemma that is taking away active, young members.

The growth of church membership in the North Zambia Field depends on the future evangelistic activities which are constantly bringing into the church souls for the kingdom. It is the responsibility of the churches in their evangelistic efforts to witness to people in the Northern and Luapula provinces of Zambia before the second coming of Christ. The Great Commission of Jesus Christ (Matt 28:20-30) tells us that not only should the coming of Christ be proclaimed, but that the church is to evangelize to make disciples of the converts in their territory. Converts who drop out quickly may become resistant to the gospel later. The church in the North Zambia Field must be made to understand and become aware that it is a waste of material and human resources when converts drop out of the church because of superficial evangelism.

Although there is good potential for strengthening conversions in small groups, there are few resources written on small groups for the Zambia context. This dissertation seeks to present a contextually appropriate model that uses small groups to enhance the work of pastors and lay people. Evangelizing new converts, bonding with newly baptized members, and nurturing the new and well-established members can be accomplished through small group ministry. Each individual member, and the church as a collective body of the North Zambia Field, needs to be strengthened in their commitment for small group ministries to be effective and to produce proper results. It is hoped with great 
confidence that small group ministry once introduced and properly managed will enhance new member retention.

\section{Description of the Study}

Chapter 2 discusses theological foundations for small group ministries found in the Bible, the writings of Ellen G. White, and general literature.

Chapter 3 discusses the theoretical foundations, functions, and characteristics of small groups in the behavioral sciences. The chapter then discusses history, functions, purposes, and reasons for small groups from the educational perspective.

Chapter 4 provides a brief history of the North Zambia Field, followed by a statistical analysis of membership growth patterns. Then comes a discussion of reasons people leave the church, the present strategies for membership retention, and the advantages of small groups for membership retention as implied by past practice in the North Zambia Field.

Chapter 5 develops a small group model for mission in the North Zambia Field, begins with a brief history, existing small groups, social assimilation (bonding) service to those in need, training for discipleship, and developing small groups for pastoral care.

Chapter 6 summarizes the dissertation and offers conclusions and recommendations for a successful small group program in the North Zambia Field.

\section{Limitation of the Dissertation}

The research was limited by cost and distance factors that prevented personal field research and a pilot program. Instead, the researcher has relied on his personal 
experience and research done by mail and telephone. The absence of published materials from a Zambian perspective has been a limiting factor. The researcher acknowledges that the dissertation contains too much material for a quick implementation and intends to start small and build the program using pilot groups. Long-term success depends on building solid foundations in the beginning. 


\section{CHAPTER 2}

\section{THEOLOGICAL FOUNDATIONS FOR SMALL GROUP MINISTRY}

This chapter defines and briefly discusses the theological foundations for small group ministry found in the Bible, in the writings of Ellen G. White, and in general literature.

\section{Definitions}

There are several definitions of a small group. In this dissertation, a small group will be defined as "a voluntary, intentional gathering of three to twelve people regularly meeting together with a shared goal of mutual Christian edification and fellowship."

According to McBride, there are seven characteristics of effective small groups:

(1) perception, (2) motivation, (3) interaction, (4) duration, (5) structure, (6) purpose, and

(7) size.

Perception is when individual members perceive themselves as group members. Motivation is when individuals not only acknowledge their group membership, but also what it is to be together and function as a group. Interaction means that a real group enjoys free and open interaction among its members, even though there may be some bumpy roads along the way. Duration talks about times of meetings. A real group meets more than once. It takes time for a group to become a group. Structure means that internal organizational structure must exist within the group. It is Important that the chosen structure is agreed upon and understood by all the group

\footnotetext{
'Neal F. McBride, Real Small Groups Don't Just Happen: Nurturing Relationships in Your Small Group (Colorado Springs, CO: NavPress, 1998), 12.
} 
members. Purpose explains the reason why the group exists. Members in the group are able to state the reason for meeting. The size of the small group varies from three to twelve persons. ${ }^{2}$

\section{Small Groups in the Old Testament}

The "Scripture is loaded with teachings, illustrations and examples of those principles that form the basis of small groups." "The Old Testament principle of organizing God's people into small groups, is logical. When a large group divides into smaller ones, each individual can receive better care and more personal attention from the group leaders and other members." ${ }^{, 4}$ Some of the examples of small groups in the Old Testament are as follows:

\section{The Triune Godhead}

The Bible indicates that the Old Testament small group model began with God. It reflects His very nature.

The small group begins with the very nature of God (Gen 1:1). It launches the biblical record with a simple yet profound statement that God (Elohim) is the creator of all that exists. The word elohim is plural, designating or incorporating more than one person. Although interpreted as singular throughout the Old Testament, the word expresses the unity of three persons in One-God the Father, the Son, and the Holy Spirit. These three share jointly in the same nature and majesty of God-a unique

${ }^{2}$ Ibid., 12-14.

${ }^{3}$ David Slamp, Care Rings: Sunday School and Small Groups (Wichita, KS: Vessel Press, 2004), 13.

${ }^{4}$ Miguel Angel Cerna, The Power of Small Groups in the Church (Newbury Park, CA: El Camino Publishing, 1991), 21. 
relationship beyond our mere human comprehension. ${ }^{5}$

Scripture points out that the concept of Trinity is the concept of relating to a group. "Trinity pictures for us the pivotal concept of relationship within a group. Our own needs for use of the group is a logical extension of the fact that God exists within the divine form of a small group. Of course, the term small group is not used in Scripture, but neither is the word Trinity."

\section{Israel as a Nation}

In choosing the Israelites, God organized the entire nation down to the smallest unit: "The concept of groups is pictured further in the Old Testament record of God's chosen people, the Israelites. The notion and practice of groups were woven into the fabric of their individual and corporate identities. From the entire nation down to the smallest family unit, a large and small group mentality permeated the Jewish existence."

The tribes of Israel were another good example of small group organization found in the Old Testament. "The house of Israel, by virtue of its descent from the twelve sons of Jacob, was divided into twelve subgroups or tribes" (Gen 49). "Tribes provided the leaders with a method to administer and guide the people. These tribal groupings were 1993), 13.

${ }^{5}$ Neal F. McBride, How to Lead Small Groups (Colorado Springs, CO: NavPress, ${ }^{6}$ Ibid., 14.

${ }^{7}$ McBride, How to Lead Small Groups, 14. 
established clearly by the time the land of Canaan was divided among the Israelites according to their tribes and families (Josh 13-22)."

The family clan in Israel is another example of a small group in Israel. "The tribes were broken down further into groups of relatives known as clans or families. By the last year of the Israelites wilderness journey, fifty-seven clans existed among the twelve tribes. The families were formed from later generations of Jacob's sons, coming from the twelve heads of the tribes. Num 26:21-46 profiles the families with their associated tribes."9

Another example of a small group in Israel is the household organized into family subgroups. This literally means "house." The various clans were divided down into family subgroups or relatives living in the same dwelling, including servants and dependents. This is the idea when Scripture speaks of "the household of Joseph" (Gen 50:8), or "Pharoah and his household" (Deut 6:22). "Households typically incorporated several generations of relatives and servants."10

The father of a family line is another example of Old Testament small group organization. A person's family genealogy was often that individual's social identifier. "A specific man, including his wife and children, was the smallest group within Jewish identity. The phrase 'son of and daughter of' were common social identifiers, linking to his or her father. A single family unit could exist as a part of a larger household or as a

${ }^{8}$ Ibid.

${ }^{9}$ Ibid.

${ }^{10}$ Ibid., 15. 
separate entity. Individual family units were the heart of Jewish society, the primary small groups. Every Jew could and maybe still can rehearse his or her identity based on nation, tribe, family, household, and father. These identity groupings were important political, social, and spiritual designations." 11

The family unit was the smallest group to nurture individuals. The "family unit created by God is a proof of the importance of small nurturing groups. We were born into a physical family group which fulfills a basic human need."12 Julie A. Gorman says that "the small group format exists as far back as the creation of family. And the group experience appear within every time period of human existence in varied expressions of human attempts at collaborations and community development." 13

The Old Testament model for small groups is also seen in Jethro's advice to Moses to share his responsibilities with others. Moses was advised to appoint leaders of tens, fifties, hundreds, and thousands-making a total of 78,600 group leaders. The leaders of tens were 60,000 , those of fifties were 12,000 , those of hundreds were 6,000 and leaders of thousands were 600 (Exod 18:19). ${ }^{14}$ Rock J. Malloy points out that in "Exodus 18 we see that the twelve Israelite tribes were then broken into smaller groups for practical reasons. This happened after Jethro, Moses's father-in-law, saw Moses trying to minister

"Ibid.

${ }^{12}$ Cerna, 18.

${ }^{13}$ Julie A. Gorman, Community That Is Christian (Grand Rapids, MI: Baker Books, 2002), 100.

${ }^{14}$ Cerna, $18-19$. 
to needs of the massive group of Israelites all by himself. Jethro rebuked Moses for his ignorance. Then he advised Moses to break the tribes down into smaller groups and to place leaders over those groups so the needs of the people could be met (Exod 18:1327). .15

The Bible outlines, in the book of Joshua, models of small group organization in the distribution of land divided into subdivisions for each family tribe during their wilderness journey. There was an arrangement for camps according to their tribes. The Israelites were to camp "around the Tent of Meeting some distance from it, each man under the standard with the banner of his family (Josh 2:2). In the East were the tribes of Judah, Issachar, and Zebulun. In the South were the tribes of Reubenites, Simeon, and Gad. In the West were the tribes of Ephraim, Manasseh, and Benjamin. In the North were the tribes of Dan, Asher, and Naphtali (Josh 2:3-27)."16

With these few examples it has been clearly demonstrated that there are biblical Old Testament foundations for small groups for the contemporary church.

\section{Small Groups in the New Testament}

Small groups were foundational and fundamental throughout Christ's earthly ministry. Jesus organized, healed, taught, and had a home-based ministry in small groups. Current writers emphasize the ministry of Jesus as basis for organizing small groups today.

\footnotetext{
${ }^{15}$ Rock J. Malloy, G-12 Group of Twelve: Launching Your Ministry into Explosive Growth (Texas City, TX: Impact Production Faith Ministries, 2002), 109.

${ }^{16}$ Cerna, 19 .
} 
Jesus used also small groups to stimulate faith and growth in others. He also trained His disciples for three and half years in a small group.

Jesus Christ is our first and greatest model for how small groups can stimulate faith and growth in others. In Jesus' first-century-world, disciples were the students of a particular teacher, apprentices who learned all that their master could teach so that they could go on to become masters themselves. In addition to teaching the Jewish law and tradition of Moses, the teachers (rabbis) sought to train their disciples to live out their faith as obedient followers of God. In Christ's call to discipleship, he challenged the disciples to "be with Him, to learn His ways and go beyond the perimeters of the rabbis, to proclaim the good news of His kingdom to others. ${ }^{17}$

Jesus started His ministry with a small group ministry of twelve disciples (Luke 4:18-21, Mark 1:15) after His baptism (Mark 1:9-11) and temptation (Mark 1:13; Luke 5:1-17) in the wilderness. He chose twelve disciples to be with Him (Mark 1:16-21; Luke 4:3-14). After addressing large crowds of people, He often retired to be with that first twelve (Matt 5:1-2). He traveled with them throughout Galilee, Samaria, Capernaum, Jerusalem, and other places for His missionary work.

Jesus also worked with His small group of twelve in healing the people (Luke 16:11-15), in the Garden of Gethsemane (Mark 14:32), and after His resurrection before His ascension (Mark 16:9-14; Acts 1:4-10). It was to the twelve that both the commission to witness to the whole world was first given (Mark 19:19-20) and the promise of His second coming announced (Acts 1:8-9; John 14:1-4). Bob Malone says that "Jesus poured out His life into twelve disciples expecting that they would change the world. That was

${ }^{17}$ Jeffrey Arnold, The Big Book on Small Groups, 2nd ed. (Downers Grove, IL: InterVarsity Press, 2004), 18. 
some small group. Imagine Matthew, a tax collector detested by Jews, with Simon the Zealot, sworn to hate all that Rome stood for. Or Peter, head strong and bold, dining with James and John, while they jockeyed for positions of power. This group went through some tough times." 18

Jesus had a small group home-based ministry. Neighbour points out that "it's significant that in Jesus' ministry he operated out of homes, not formal buildings. He often taught His disciples in houses (Mark 2:1; 7:14-27; 9:33; 10:2-12; Matt 13:36). We frequently see Him in the homes of others, including Peter, Matthew, a ruler, Simon the leper, Simon and Andrew, Levi, a Pharisee, Jairus, Zacchaeus, and Martha. He referred to the owner of a large home in Jerusalem who would consider his upper room Jesus' 'guestroom' (Mark 14:14)."'19

\section{Small Groups in the Apostolic Church}

Apostles in the New Testament organized the fledgling church into small groups. For example, they met in small groups at Pentecost, for prayer, worship, and during Paul's journeys. Apostles met at Pentecost in a group of followers of Christ (Acts 2). The believers met in a small group to pray for Peter for the Lord to hasten his release from prison (Acts 12:1-17).

${ }^{18}$ Steve Baker, Judy Johnson, and Bob Malone, Good Things Come in Small Groups: The Dynamics of Good Group Life (Downers Grove, IL: InterVarsity Press, 1995), 18.

${ }^{19}$ Ralph W. Neighbour Jr., Where Do We Go From Here? A Guide for the Cell Group Church (Houston, TX: Touch Publications, 1990), 42. 
Later on, as the missionary work expanded, Christian believers continued to meet for prayer and worship as small groups in houses (Acts 12:12). For example, Paul (Acts 16:11), in Corinth (Acts 18:1ff), at Nymph (Col 4:15), and in Rome (Rom 16:5). "Primitive Christianity structured its congregations in families, groups and houses. The house was both a fellowship and a place of meeting.... The house and family are the smallest natural group in the total structure of the congregation." ${ }^{.20}$ The "meeting in houses did not divide the church or cause disunity. It built the church. The temple meetings grew as the house churches meetings grew. Fellowship and eating together developed singleness of heart. Unity produced favor in the community, which helped to build the church."21

In Acts the new covenant community continues gathering together in houses and upper rooms for praying, mutual sharing the faith, and expressing devotion to the same Lord and support for his cause. Robert Banks, a champion of house church movement, suggests that the New Testament church existed primarily in people's homes (Acts 2:43; 16:40; 20:8; Rom 16:5; 1 Cor 16:19; Col 4:15; Phlm 2). He further observes that Paul and other apostles primarily chose converted household units as nuclei for founding churches (Acts $11: 14 ; 18: 18$ ). The small home group was central to the development of the church. ${ }^{22}$

Furthermore:

The early Christians saw their homes as fit places in which to worship God and enjoy fellowship with one another. There was time for public activity and there was a time to come together as fellow believers in the privacy of their homes. For example, Acts 2:46 tell us that early Christians in Jerusalem "continued to meet together in the

\footnotetext{
${ }^{20}$ John Mallison, Growing Christians in Small Groups (Homebush, West, NSW, Australia: Scripture Union Books Anzea Publishers, 1993), 5.

${ }^{21}$ Malloy, 111.

${ }^{22}$ Gorman, 101.
} 
temple courts" and that "they broke bread in their homes and ate together with glad and sincere hearts." Similarly, in Acts 5:42 we read, "Day after day, in the temple courts and from house to house, they [the apostles] never stopped teaching and proclaiming the good news that Jesus is the Christ" [emphasis added]. Thus along with ministry among the crowds, quieter times spent within individuals' homes helped the early believers become people who were spiritually alive and in love with God and each other. ${ }^{23}$

The Apostles, during the early formative years of the church, gathered as small groups in believer's homes. John Mallison states, "From inception, the early church Christians placed the private home alongside the temple as a focus for their fellowship together." ${ }^{24}$ The Apostles and the believers "And they, continuing daily with one accord in the temple, and breaking of bread from house to house did eat their meat with gladness of heart ..." (Acts 2:46).

\section{Small Group Communities in Church History}

In the history of the early church and the Middle Ages, the emergence of small groups can be seen. Some examples are St. Francis of Assisi's monastery, the Anabaptist movement, the Hutterites of Germany, George Fox, the Lutherans, and the Methodist Church. St. Francis of Assisi "gathered in small groups for prayer and study, and training and service. They kept the flame burning amidst the darkness of decaying ecclesiasticism." "Various sections of the Anabaptists movement in Europe formed

\footnotetext{
${ }^{23}$ Slamp, 17.

${ }^{24}$ Mallison, 4 .

${ }^{25}$ Ibid., 6.
} 
dynamic house-centered groups. ${ }^{26}$ For example, the Hutterites in Moravia, Southern Germany, "lived out a New Testament-style of community life which had far reaching impact." small groups which became known as the Religious Society of Friends. ${ }^{28}$ Small groups in England and Germany pursued renewal in their actions in the churches. "Many of these small groups (Pietists, Quakers in England, and Moravians in Germany among others) pursued renewal in churches through their actions. One outstanding result of these groups was the creation of a new high in credibility of lay persons as priests serving both God and humankind. As such this group influence was profound. ${ }^{29}$

\title{
Ancient and Secular Small Group Organization
}

It is prudent to state that small groups are not found in the church alone but also in other organizations in various societies. For example, small groups were found in armed forces in China and Rome. Ancient and modern armed forces in Europe and in Asia have used the small groups successfully and small groups produced wonderful results in China. The ancient Chinese used the small group concept in war to improve communication, specialization, and mobilization. The ancient Chinese used a cell concept in war, much as nations do today in their modern day armed forces, where it is also used to improve morale

\author{
${ }^{26}$ Ibid. \\ ${ }^{27}$ Ibid. \\ ${ }^{28}$ Ibid. \\ ${ }^{29}$ Gorman, 102.
}


and reinforce camaraderie. "The Chinese broke down their army into smaller units of divisions and companies, with the smallest unit being a squad, or a group of 5 soldiers. When the General gave an order, it passed through the ranks until it finally reached the squad of $5 . " 30$

The ancient Roman armed forces used small groups in their military activities. They were able to conquer the world using a sword the size of a kitchen knife. Malloy says that "the Romans conquered the world with a sword the size of a kitchen knife, and the concept of small groups for specialization and communication. Instead of five units, however, they used sixteen units. Like the Chinese the Romans learned from experience that it is much easier to maneuver on the field of battle if the larger force is broken down into smaller units. ${ }^{.31}$

Nowadays, in modern military circles small groups are used for communication purposes. Churches can learn a lesson from the general in the army issuing a command to 100,000 . In great nations of the world "the same techniques are used today with modern armies. The generals meet; orders are then passed along to the colonels, majors, captains, lieutenants, platoons, sergeants, and so forth. The communication finally reaches all the way down to the smallest unit or squad comprised of 8 to 12 men."32

\footnotetext{
${ }^{30}$ Malloy, 112-113.

${ }^{31}$ Ibid., 113.

${ }^{32}$ Ibid.
} 


\section{Small Groups in Modern Times}

Today, churches use small groups in spreading the Gospel to the world. First of all, small groups are a way of taking the gospel to where the people are. Mallinson declares, "The Gospel must be brought back to where people live, in simple forms and in terms of small and manageable fellowships." ${ }^{.33}$ Second, "the small group has always been a significant force for renewal in the Christian church, but its place is being rediscovered again in our time. In the last three decades or more, what Hobart Mowrer calls 'quiet revolution' has been taking place. Around the world, one of the signs of hope in the Christian church has been the renewal being brought to individuals and Christian communities through the formation of small groups. ${ }^{134}$

\section{North America}

In the United States of America, small groups are growing like wild fire and with great success. For example, the "small group movement is now poised to exercise even greater influence on American society in the next decade than it has in the last two decades. The resources are there, models have been developed, leaders have been trained, national networks have been established, and millions of satisfied participants are ready to enlist their friends and neighbors." 35

${ }^{33}$ Mallison, 1.

${ }^{34}$ Ibid.

${ }^{35}$ Michael C. Mack, The Synergy Church: A Strategy Integrating Small Groups and Sunday School (Grand Rapids, MI: Baker Books, 1996), 56. 
A good number of Americans are in small groups of some sort. A study has been done which shows that small groups are a powerful, significant force in American culture. For example, "Sociologist Robert Wuthnow of Princeton University, in partnership with Gallup organization, has completed a significant study of small groups in American culture, entitled Sharing the Journey. His conclusions illustrate both good and bad news: About 45 percent of Americans are in some form of a small group, and many more indicate an interest in joining one or more groups. Of those people in groups, 60 percent are in church-related groups, and a large portion of the remaining 40 percent are studying spiritual issues. These statistics demonstrate that small groups are a powerful, significant force in American culture. ${ }^{936}$ However, these observations were done in 1990, there have been changes, and Pastor D. Galloway no longer works for the church..

In America, small groups are springing up everywhere in the nation. For example: “In America Portland's New Hope Community Church has set a goal to reach 100,000 people by the year 2,000 through "Tender Loving Care Group." Pastor Dale Galloway tells of the crucial decision he made to totally scrap the traditional form of the church." Neighbour also says that "cell group churches are springing up in all parts of the nation."

\section{South America}

Small groups are flourishing very well in South America so much that it is called the "granddaddy" of the cell movement. "In Santiago, Chile, the Pentecostal of all cell

\footnotetext{
${ }^{36}$ Ibid., 17.

${ }^{37}$ Neighbour, 34.
} 
group churches numbers over 40,000. In Brazil, at least one cell group church has erected a 25,000 seat auditorium. Cell group churches exist all over the continent, both among the Evangelicals and Roman Catholics who call them Communidades de Base. A Baptist Pastor in Calli, Columbia, calls his cells Grupos de Amor."38 "In South America the Catholic Church incorporated the assets of the cell format in its communities. Reflecting the pattern of liberation theology, these small groups burst forth among the laity to express concerns for the poor and to foster promotion of justice. They found an eloquent spokesperson in Leonardo Boff (Ecclesiogenesis of the church). ${ }^{.39}$

\section{Asia}

Cell-group churches are growing rapidly in Asia. They say that this rapid growth is unparalleled anywhere else in the world. They start with cell group churches in Korea as "the largest single church in the history of Christianity exists in this land. It is the Yoido Full Gospel Church in Seoul, Korea. It has grown from five people who gathered in a tent in 1958 , to a congregation of over 600,000 in $1989 .{ }^{.40}$

Second, in Japan a Korean woman was sent by Pastor Paul Yonggi Cho to go and open a small group church or cell-group church. From that humble beginning it had committed to have had ten million converted Japanese by the year 2000 . The "potential of

\footnotetext{
${ }^{38}$ Ibid., 33-34.

${ }^{39}$ Gorman, 104.

${ }^{40}$ Neighbour, 26.
} 
Christianity spreading in Japanese culture is greatly enhanced by restructuring the life of the church to be relational, small group, and home centered. ${ }^{.41}$

Third, Yonggi Cho, pastor of the largest church in the world in Seoul, Korea, the Yoido Full Gospel Church, "claims that this church is not only the largest but the smallest, because from most members' perspective, their church fellowship is only ten to twenty in number. Members meet for celebration and worship in huge crowds in their stadium-like building, but during the week 650,000 of them serve the church and are served by it through 55,000 small groups. There is no sense of lostness or anonymity when people "go to church" because they know and regularly experience the fact that they belong. ${ }^{, 42}$

\section{Singapore and Thailand}

Singapore is another country in Asia where small group churches or cell churches are thriving. This is the country where Baptist pastor "Lawrence Khong developed a small group church (cell group church) in 1986 which grew to 4,500 in about four years. ${ }^{93}$ In Thailand small cell groups were began by Chareonwonsak Krengsak, a Buddhist convert who went to study for his Ph.D. in economics in Melbourne, Australia. When he came

\footnotetext{
${ }^{41}$ Ibid. Pastor Paul Yonggi Gho "sent a Korean woman to plane the first cell group church in Japan just a few years ago. From a humble beginning the cell has grown and grown. He [had] committed to have [had] ten million converted Japanese in cell groups by the year 2000."

${ }^{42}$ David Cox, Think Small Groups: Building Community (Watford, Herts, England: Department of Personal Ministries, The South England Conference of Seventhday Adventists, 1998), 35.

${ }^{43}$ Neighbour, 27.
} 
back to Thailand he formed small cell groups in his township. He called his small groups church "Hope of Bangkok" which exploded across the city and is engulfing the entire nation. His movement has now surpassed the five thousand mark in Bangkok, only a handful of years after it was launched. ${ }^{44}$

\section{China and Hong Kong}

On mainline China small groups are thriving, too. For instance,

The expansion of the church under persecution of the Communist regime in China has been through the use of small cells. Recent reports indicate the movement is still expanding, still underground, still cynical of the government and unwilling to "go. public." Yoggi Cho is scheduled to preach in China, the Lord willing. He told me his report reveals there are between fifty and seventy-five people meeting in these small groups at the present time. Mainland China is a living proof from century to century, the cell group church has preserved the Christian community from those who would oppose it. China is the contemporary illustration that it still works. ${ }^{45}$

Another country where small groups are growing is in Macau where "Pastor Lam at the Campus Crusade for Christ,[is] also pastor [of] a local cell group of 2,000

members. ${ }^{.46}$ Small groups growing

in Russia and mainland China, Christians facing persecutions and the impossibility of institutional church gathering, formed clandestine underground house groups that essentially kept the church alive during the dark days of communism and cultural revolution. Although estimates vary, there are probably more than fifty million believers in China today. The number attending official churches is at most only several millions. which means that house churches are far and away the "mainstream" form of church life in mainland China. ${ }^{47}$

${ }^{44}$ Ibid., 28.
${ }^{45}$ Ibid., 29.
${ }^{46}$ Ibid., 30.
${ }^{47}$ Gorman, 104. 
Cox says, "In countries like China were the church has been prosecuted and threatened with extinction, it has not only survived, but flourished, through the ministry of small groups, despite the absence of professional pastoral leadership." ${ }^{\$ 48}$ Small groups were launched a few years ago "within little more than a year, two separate groups have launched cell group church movements in this colony, which will return to Chinese control in $1997 .{ }^{.49}$

\section{England}

Small groups or cell groups were launched in England, too. "ICHTHUS Fellowship in south west London has penetrated the residents of the area, deliberately forming cells by using the 'checkerboard pattern.' After cells are planted on the 'red' square, the members are challenged to create a cell in the "black" space between them."50 They report that the cells are led by Roger Foster and in "October 1990, they had 200 cells in 32 London congregations and three congregations in the Middle East." ${ }^{\text {"1 } 1}$ It can be seen that in England "the influence of David Prior, Michael Green, and the Alpha course have kept alive small cell and house groups in England and Scotland. In Hungary, one source reported six thousand groups in existence in 1987. Even in East Germany before the Wall

\footnotetext{
${ }^{48} \mathrm{Cox}, 17$.

${ }^{49}$ Neighbour, 30-31.

${ }^{50}$ Ibid., 32.

${ }^{51}$ Ibid., 33.
} 
came down, small Christian communities were keeping the faith (1996)"s2 Finally, small groups are growing in England. "In England approximately one million individuals are now involved in Christian small groups, which the Holy Spirit appears to be using to win unbelievers to faith, revitalize the spiritual lives of individuals and congregations, and focus attention on the study of the Bible." ${ }^{93}$

\section{Australia}

Small groups in Australia started in Brisbane. Cell groups in Australia have engulfed all the major cities, towns, and villages as launched by The Christian Outreach Center. "It is the cell group church movement which has now penetrated dozens of cities across the continent." "In Australia, there is also significant growth in people gathering in small groups. A few churches are reporting $75 \%$ of their membership actively participating in house centered cells." ${ }^{.55}$ During Mrs. White's visit to Australia, the Seventh-day Adventist members in Melbourne formed 200 small groups. At that same time "a major Christian revival took place in Melbourne, at the height of which 2,000 small groups were meeting in homes all over the city."556

\footnotetext{
${ }^{52}$ Gorman, 105.

${ }^{53} \operatorname{Cox}, 17$.

${ }^{54}$ Neighbour, 33.

${ }^{55}$ Mallison, 2.

${ }^{56} \mathrm{Cox}, 17$.
} 


\section{Africa}

In Africa small cell group churches have been launched. The church of Eglise Protestante Baptist Ceuvires had a part in launching from Abidjani in the Ivory Coast, with 638 to 2,300 members. This church has now established cell church extensions in several other African nations and even works in Paris with Francophone Africans who have migrated there. ${ }^{57}$ "Reports indicate that cell groups and house churches are on the increase in India, Philippines, other parts of Asia, and Africa where group communities are well integrated into the mainstream church." $\$ 8$

\section{Zambia}

Pastor Sinyangwe, the Ministerial Director of the North Zambia Field, reported that small groups were launched in the Seventh-day Adventist Church in 2004. To date, there are 30 fellowship groups, 256 Bible study groups, 27 cell groups, 259 outreach groups, 1 task/ministry group, 14 support groups, 184 prayer groups, and 602 Sabbath school units. ${ }^{59}$

\section{Small Groups in the Writings of Ellen G. White}

Ellen G. White, a co-founder of the Seventh-day Adventist Church, has written extensively on small companies or small groups in churches. All would do well to heed the counsel of her writings on small groups or companies and take them seriously ( $2 \mathrm{Chr}$

${ }^{57}$ Neighbour, 31.

${ }^{58}$ Gorman, 105.

${ }^{59}$ These ten types of small groups were extracted from the Questionnaire for the North Zambia Field Survey of 2005-2006. 
20:20). She says that formation of small companies or groups is a divine idea that comes from God. She advises the church to start forming small companies in their territory for reaching out to non-believers and for encouraging each other.

\section{Small Groups as the Basis for Christian Effort}

White recommends the formation of small groups or companies as the church as a basis for Christian effort. The "formation of small companies as a basis for Christian effort has been presented by one who cannot err." 60 "Let there be in every church, wellorganized companies of workers to labor in the vicinity of that church."" "In our churches there should be corps for service." ${ }^{62}$ The "Church of Christ on earth was organized for missionary purposes, and the Lord desires to see the entire church devising ways and means whereby high and low, rich and poor, may hear the message of truth." ${ }^{93}$ Small groups or companies are to work for both believers and non-believers. "If there is a large number in the church, let the members be formed into small companies, to work not only for the church members, but for unbelievers. If in one place there are only two or three who knows the truth let them form themselves into a band of workers. ${ }^{.64}$

${ }^{60}$ Ellen G. White, Testimonies for the Church, vol. 7 (Boise, ID: Pacific Press Publishing Association, 1948), 21-22.

${ }^{61}$ Ellen G. White, Welfare Ministry (Washington, DC: Review and Herald Publishing Association, 1952), 107.

${ }^{62}$ White, Testimonies for the Church, 7:21.

${ }^{63}$ White, Testimonies for the Church, 6:29.

${ }^{64}$ Ibid., 22. 


\section{Counsels to Churches}

The churches are to form small groups to reach out to unbelievers in their neighborhood: "In our churches let companies be formed for service. Let different ones unite in labor as fishers of men. Let them seek to gather souls from the corruption of the world into the saving purity of Christ's love." ${ }^{.65}$

Members in their small groups or companies should have time to give testimonies. "All who are pursuing the onward Christian course, would have, and will have, and experience that is living, that is new and interesting. A living experience is made up of daily trials, conflicts and temptations, strong efforts and victories, and great peace and joy gained through Jesus. A simple relation of such experiences gives light, strength and knowledge that will aid others in their advancements in the divine life. ${ }^{.66}$

White encourages members in the church to attend social meetings which are similar to (small groups) because when they do that they are in the school of Christ. "Although the social meeting is a new thing, yet they are learning in the school of Christ and are overcoming fear and trembling. We keep before them the fact that the social meeting (similar to small group meetings) will be the best meeting in which they may be trained and educated to be witnesses for Christ. ${ }^{.67}$

${ }^{65}$ Ibid., 21.

${ }^{66}$ White, Testimonies to the Church, 2:578.

${ }^{67}$ Ellen G. White, MS32, 1894, Center for Adventist Research, Andrews University, Berrien Springs, MI. 
White encourages members to work for families. The family is the best form of a small group. Members should go out to present Christ to families. The "presentation of Christ in the family, by the fireside and in small gatherings in private houses, is often more successful in winning souls to Jesus than are sermons delivered in the open air, to the moving throng or even in halls or churches. 968

She urges every member to take his or her appointed duty. "He [God] calls upon the church to take up their appointed duty, holding up the standard of true reform in their own territory, leaving the trained and experienced workers to press on into new fields." Every member should do his work in his way and work for the salvation of others:

God's work is to be done in his way and his Spirit. In various places small companies are to concentrate to God, body souls, and laying hold of the throne of God by faith they are to work zealously keeping the souls in the love of God. The vital current of his love will make itself felt, and will be recognized as from heaven in the works of his people. Those little companies who know the truth with one voice should bid their minister go to the lost sheep of the house of Israel. Each one should seek to do individual work for another. Not one who has tasted the goodness, the mercy, and the love of God, can be excused from working for the souls of others. "Followers of Christ" will be Missionaries. ${ }^{70}$

White tells members of the Seventh-day Adventist Church to "preach less and educate more by holding Bible reading, and by prayer with families and little companies ... Take your Bible, and open before them its great truths. Your success will not depend so much upon your knowledge and accomplishments, as on your ability to find your way

${ }^{68}$ White, Welfare Ministry, 91.

${ }^{69}$ Ellen G. White, Christian Service (Washington, DC: Home Department of the General Conference of the Seventh-day Adventists, 1947), 14.

${ }^{70}$ Ellen G. White, Advent Review and Sabbath Herald, 8 January 1895. 
to the heart."71 "Let small companies assemble in the evening, at noon, or in the early morning to study the Bible. Let them have a season of prayer, that they may be strengthened, enlightened, and sanctified by the Holy Spirit." ${ }^{372}$

White states that small groups or companies promote the unity of all believers. It is easier to develop unity among church members in small groups than in a large church of many members. She says, "Let them keep their bond of union unbroken, pressing together in love and unity.".73

She urges the church to nurture new church members through small groups or companies.

Let small companies assemble in the evening, at noon, or in the early morning to study the Bible. Let them have a season of prayer, that they may be strengthened, enlightened, and sanctified by the Holy Spirit. This work Christ wants to have done in the heart of every worker. If you yourselves will open the door to receive it, a great blessing will come to you. Angels of God will be in your assembly. You will feed upon the leaves of the tree of life. What testimonies you may bear of loving acquaintances made with your fellow workers in these precious seasons when seeking for the blessing of God. Let each tell his experience in simple words. This will bring more comfort and joy to the soul than all the pleasant instruments of music that could be brought into the churches. Christ will come into your hearts. It is by this means only that you can maintain your integrity. ${ }^{74}$

${ }^{71}$ Ellen G. White, Gospel Workers (Washington, DC: Review and Herald Publishing Association, 1915), 193.

${ }^{72}$ White, Testimonies for the Church, 7:195.

${ }^{73}$ Ibid., 195.

${ }^{74}$ Ibid. 


\section{Small Groups in General Literature}

Several writers have written about small groups in general literature. Their goal is to see that small groups are developed and organized properly with trained leaders. They have enabled those who are anxious to start small groups in their churches, to have textbooks to teach from and for their references. Let us look at the different varieties and functions of small groups in general literature.

\section{Different Varieties of Small Groups}

Writers say that there are different varieties of small groups in church denominations and in different civic organizations. "Some small groups meet for fellowship and support. Others meet to address specific life topics such as marriage, parenting, dating, addiction, or divorce recovery. Still others gather to study the Bible or to grow spiritually or even engage in spiritual formation"75 "Throughout the world today there is a wide spread increase in variety and number of small Bible study groups ${ }^{976}$

In a church setting, there are several kinds of small groups that qualify as part of a church's ministry. For a small group to qualify, it should be a group that is concerned with discipleship; have a covenant, be affinitive, and emphasize worship, prayer, and teaching

\footnotetext{
${ }^{75}$ Henry Cloud and John Sims Townsend, Making Small Groups Work: What Every Small Group Leader Needs to Know (Grand Rapids, MI: Zondervan Publishing House, 2003), 13.

${ }^{76}$ Roberta Hestenes, Using the Bible in Groups (Philadelphia, PA: The Westminister Press, 1983), 9.
} 
ministry. The group should be involved in attending to special needs, be a ministry group and be evangelistic. Here are some of the main small groups types:

1. Discipleship groups--emphasizing deep, intense relationships, these groups are usually small in size (two to four members).

2. Covenant groups--the most prominent group type in the church (also called $\mathrm{K}$ groups, "caring groups," Bible studies and a host of other names) these groups typically focus on study, prayer and community building

3. Affinity groups--these groups possess any of the emphases in this list, and involve people of a common race, gender, age, interest, or other characteristic.

4. House churches--often larger than the classic small groups, these groups emphasize worship, prayer, and teaching ministry.

5. Special needs groups-these groups can involve persons in various types of crises (physical, emotional, or relational) such as recovery.

6. Ministry groups--these teams of individuals serve either within the church or within the community.

7. Evangelistic groups--these groups exist in order to evangelize friends and acquaintances. ${ }^{77}$

\section{Functions of Small Groups}

There are several functions of small groups in the church denominations and civic organizations. For example, in the church setting experts agree that a small group is a powerful tool and that it provides several functions. They also state that "through participating in small groups, leading them, training their leaders, consulting for them, and researching them, we have come to believe that a small group is without a doubt one of the most powerful tools of life change and spiritual growth." 78

Small groups develop a closer connection with God. "Closer connection with God develops as people connect in a group. Our vertical disconnection often has to do with

\footnotetext{
${ }^{77}$ Jeffrey Arnold and Herb Miller, Starting Small Groups: Building Communities That Matter, 24, 25.
}

${ }^{78}$ Cloud and Townsend, 14. 
our horizontal disconnection. Whatever keeps us from loving others can prevent us from loving God. 'For anyone who does not love his brother, whom he has seen, cannot love God, whom he has not seen"'(1 John 4:20). ${ }^{79}$

Small group members learn integration of their character. "Groups are a powerful force to develop integration." ${ }^{80}$ This helps them to be aware of themselves in order to accept their own experiences as either good or bad. This element in their growth is healthy for members of the group because "groups also foster integration in the character of their members. ... Integration is the state of accepting, experiences and dealing with all parts of our selves, good and bad." ${ }^{\prime 81}$

One small group expert has declared that the best way to develop leaders is with small groups.

Small group expert Carl George recently responded to one person's question, "If I had to choose, it is more important to develop small groups in my church or train leaders?" George responded that the more important task is to train strong lay leaders. He added that the best way to develop leaders is with small groups. When the sort of training George mentioned is carried out, it is remarkable to see laymen and women who have wanted for years to do something significant with their lives finally getting involved in ministry. ${ }^{82}$

Slamp adds that "when God is involved smaller is better and less is best."

${ }^{79}$ Ibid., 59.

${ }^{80}$ Ibid., 62.

${ }^{81}$ Ibid., 61.

${ }^{82}$ Carl George, Prepare Your Church for the Future (Grand Rapids, MI: Revell, 1992), 31, quoted in Slamp, 15.

${ }^{83}$ Slamp, 17. 
Today, small groups continue making disciples for Christ. Disciple making comes in three ways: First, disciples are made intentionally because "just as children don't grow up without personal care, or learn mathematics on their own, so discipleship will not occur without faithful Christians being intentional about meeting together." ${ }^{84}$ Second, the disciples are to be like Christ in character. Christ should be formed in them and they should practice a Christlike life in the community. The "New Testament writers, most notably Paul, speak of a far higher goal: that Christ may be formed in us. In small groups and with other believers, we 'practice' the Christian life together in the community. Then Scripture teaches us, the Spirit of God works to apply lessons learned into the deepest recesses of our hearts. We become, in the deepest sense, like Christ." ${ }^{185}$ Third, disciples are made in relationships. It is said that no man is an island. "We learn about life through the relationships in which we participate. So the Christian life is the same. There is no example in the Scriptures of a lone disciple. Even Paul, after his dramatic conversion and a long stay in the desert, went to Jerusalem and associated himself with the apostles and later with the church at Antioch (Acts 9:26-30). ${ }^{986}$

Small groups are for building up the church. Small groups build the church up by providing love and care in many ways such as helping members discover their spiritual gifts and practicing effective congregational care. "Healthy groups will attach people

\footnotetext{
${ }^{84}$ Arnold, The Big Book on Small Groups, 23.

${ }^{85}$ Ibid., 24.

${ }^{86}$ Ibid., 25.
} 
deeply to their God and show them how to minister to the world." ${ }^{87}$ Small groups help to develop lay leadership in the church. They provide opportunities for development of the lay leadership in their skills and styles. "They can be the keys to finding 'anonymous' members, discovering their leadership potential and developing that potential for the benefit of the church. In this way the church finds that the ministry of many replaces the ministry of the few." ${ }^{88}$

Writers agree that small groups enable members to reach inward by nurturing them and by worship. As a result, they engage their members in regular fellowship.

Small groups are a great means of helping a congregation to care deeply for fellowship members.... This is why groups that meet regularly engage in nurture and worship ... first, by nurturing, group members discovered that their knowledge of God's word and their confidence in His promises and trustworthiness increased with every passing month.... When it comes to thanksgiving and praise, the group members thank God for answered prayers and that the entire church is beginning to change. ${ }^{989}$

One of the traits that small groups have is outreach. It is "an indispensable trait of healthy groups. Because of the powerful dynamics that accompany small group outreach, an outward focus can keep a group vital, refreshed and challenged." 90 The three traits that keep the small groups healthy are evangelism, spiritual and numerical growth, and multiplication. "Biblical evangelism is not a program but a person-to-person process of sharing the good news about the forgiveness of sin and a new life in Jesus. Because small

$$
\begin{aligned}
& { }^{87} \text { Ibid., } 39 . \\
& { }^{88} \text { Ibid., } 35 . \\
& { }^{89} \text { Ibid., } 36 . \\
& { }^{90} \text { Ibid., } 38 .
\end{aligned}
$$


groups are likely to be the most personal setting offered by a church, they are natural places for this kind of evangelism to take place. In addition, groups provide a rallying point for evangelism opportunities." ${ }^{\text {11 }}$

Small groups promote retention of new members in the church. Small groups "attract and keep new church members, and provide a place to sink roots and grow for people who might otherwise end up on the margins of a church. They attract people to their God and show them how to minister to the world. ${ }^{992}$

Small groups wield the power of the body of Christ because the groups enable the entire body of the church to be joined and held together. "We have witnessed the power of the body of Christ wielded in the small groups: From him the whole body, joined and held together by every supporting ligament, grows and builds itself up in love, as each part does its work" (Eph 4:16). ${ }^{93}$

Small groups provide the power of the church in the gifts that God has given to all believers to meet their needs. God has placed many different gifts in His people to meet those needs. Indeed, we are a body. "In His grand design we exercise those gifts with each other and help each other grow. The small group is one of the best ways for this to

\footnotetext{
${ }^{91}$ Ibid., 38, 39.

${ }^{92}$ Ibid., 39.

${ }^{93} \mathrm{Cloud}$ and Townsend, 16.
} 
happen. So it is no surprise that churches are rushing headlong into the small group movement." 94

Small groups can address cultural and social needs in four different ways. They can provide a safe place, build relationships, fellowship, and Christian discipleship. The small groups can help to address deep culture and social needs in at least four ways:

1. First, small groups provide a safe place where people can be heard.

2. Second, small groups can give our dysfunctional society a positive model of building healthy relationships, helping to strengthen the family and other interactions.

3. Third, since people are known deeply in small group settings, they are prayed for, cared for and challenged in a way no other church structure can offer.

4. Fourth, small groups can keep people on the cutting edge by constantly demanding more in the way of Christian discipleship. ${ }^{95}$

Small groups were used for survival by Christians during the expulsion of missionaries from China and persecutions of the early Christian Church in the Holy Land. "Christians [have] managed to survive with the expulsion of missionaries, the shut down of centers for worship, and persecutions which was sometimes very harsh. The news from China today is staggering; not only has China survived, it has actually grown. How is this possible? House fellowship! Christians in China by hundreds and thousands have met in small informal home gatherings for worship, Bible study, and prayer. In these settings they have found strength to continue in their Christian faith. ${ }^{\prime 96}$

\footnotetext{
${ }^{94}$ Ibid., 13-14.

${ }^{95}$ Arnold and Miller, Starting Small Groups, 18.

${ }^{96}$ Hestenes, 9-10.
} 
Small groups have been one way for nurturing personal faith, for people to discover themselves, what it means to be a Christian, and to participate in Christian community. Small groups have helped to develop lay leadership energies and thus strengthen the church.

During the period of renewal in church history, small groups have been one of the ways in which vital personal faith in Jesus Christ has been nurtured and encouraged. Small groups have been used in order to help people to discover for themselves what the Bible says and what it means to be a Christian and to participate in Christian community. They have been used as a means for the church to reach out beyond its active membership. Lay leadership is energized in small group involvement and the church is strengthened. ${ }^{97}$

There is enough training and resources in small groups. These materials help members of small groups relate well to the church and make them the most enthusiastic supporters and leaders of the church. "Groups which have been provided with useful resources, training, and help usually relate in a positive way to the larger congregation. Many churches report that some of their strongest and most enthusiastic supporters and leaders have been participants in well-organized small groups."98

Small groups always provide opportunity for security and safety, love, support, care and fellowship (koinonia).

In small groups of three to twelve people, there is an opportunity to explore the meaning and application of Christian faith in a setting which provides a degree of security and safety. Healthy small groups can be a place where members learn how to love one another. Beyond that, good small groups provide supportive relationships which sustain Christian caring for people outside the group itself. Sustained ministry flows from supportive relationships. Costly discipleship can be nourished in a circle

$$
\begin{aligned}
& { }^{97} \text { Ibid., } 10 . \\
& { }^{98} \text { Ibid., } 17 .
\end{aligned}
$$


of care and concern. As Christians experience both the joy and struggles involved in Christian life, a small group drawing upon the resources of Scripture for inspiration and encouragement can experience the reality of "koinonia" of Christ with the people. ${ }^{99}$

Small groups build new member identity formation in the new church. They make new friends and are easily identified with other new and old members of the church. So, they feel that "it is not the individual's capacity to think which is the prime source of his or her identify formation, but rather the reality and the ability of belonging, participating and sharing. The sharing of one's life with another's leads to wholeness and guarantees health." $" 100$

Sometimes new members feel openness, love, kindness, friendliness, caring, and common concern as they experience the small group and they feel that they are at home away from home. They say that after several months together of learning the struggles and victories present in each life, the group becomes a context of caring and common concern. It becomes "the home away from home." As people share (have a part in the lives of others) they become willing to speak the truth about their lives and God's intention for each person. Making time for exchanging experiences of the spiritual journey enhances self-discovery and provides mutual support. ${ }^{101}$

${ }^{99}$ Ibid., 14.

${ }^{100}$ Corinne Ware, Connecting to God: Nurturing Spirituality Through Small Groups (Bethesda, MD: Alban Institute, 1997), 70.

${ }^{101}$ Ibid. 


\section{Why Small Groups Are Important Today}

Small groups in churches are important because of social-cultural, biblical, and theological factors. Second, small groups are important today because they deal with issues of the people in the community.

\section{Social-Cultural Factors}

Small groups can help to address deep cultural and sociological needs in at least four ways where people can be heard, for relationships, cared for, and for discipleship. ${ }^{102}$

\section{Biblical Reasons}

A biblical basis has already been discussed. In summary, the Bible supports small groups in the Old Testament, in the life and work of Jesus, and in the life and work of the Apostles. In Israel, the starting point was with family. "The Old Testament framework for the Israelite society revolved completely around the family. The twelve 'tribes' traced themselves to patriarchal heads of family. Within the family there were clans (larger family groupings) followed by households, and then nuclear families. God designed the Israelite nation around the concept of family. in order to show the importance of deep, long-lasting relationships." 103

Jesus employed small groups to reach out to the people. He had twelve disciples (apostles), an inner-circle of three friends and 120 larger circles and the crowds. Jesus employed a similar approach. He had an inner circle of three close friends, 12 disciples (apostles), a larger circle perhaps of 120 disciples, and the crowds. In His own life, Jesus showed the importance of deep friendships and Christian community. Echoing the Old Testament, Christ called His disciples to 'Love the Lord your God

\footnotetext{
${ }^{102}$ Arnold and Miller, Starting Small Groups, 18.

${ }^{103}$ Ibid.
} 
with all your heart and with all your soul and with all your strength and with all your mind' and 'Love your neighbor as yourself' (Luke 10:27). ${ }^{104}$

The apostles met in small groups in house churches. "The early church did not have buildings until several centuries after Christ. Since most homes were fairly small and few early believers were affluent, the early church was a small group ministry, and it functioned quite well. These small groups did not need to create mega-staff structures in order to meet needs. Everyone received care as part of the body."105

There is enough evidence in the Bible, particularly in the New Testament writings, that talk about small house churches in different locations. Early biblical writings were specifically addressed to these small congregations of believers in the New Testament era. "The New Testament writings, addressed to house churches in different locations, illustrate the need for deep, spiritual relationships." 106

\section{Theological Reasons}

When it comes to theological reasons why small groups are important, it can be seen that small groups build relationships. They exist to facilitate the building of permanent good relationships between the individual believer and God. It is important that a relationship be built among members for the group to survive. For instance, "Take any good systematic theology book and attempt to locate a doctrine that has nothing to do

\footnotetext{
${ }^{104}$ Ibid.

${ }^{105}$ Ibid.

${ }^{106}$ Ibid.
} 
with relationships. Every doctrine and every creed speaks to relationships. For example, the Lord's Supper (1 Cor 11:26) demonstrates relationships." ${ }^{107}$

Small groups can build and strengthen the church as the organic body of Christ. Authentic Christian theology is relational. Good relationships are part of God's plan on several dimensions: between the believer and God; between individual believers; within the corporate body of Christ (the church); and between believers and non-believers. Small groups can facilitate the development of good relationships in all of these dimensions.

\section{Small Groups Build Community}

Small groups are important in building community. They help to build up strong healthy community in the churches. The eight small group goals in building community are:

Inclusive-accepting of all.

Realistic-containing freedom to express individuality, to be honest, to face facts.

Contemplate-self-examining.

A safe place-a place where people can take off their masks.

A laboratory for personal disarmament-where we can experiment and take risks.

A place to fight gracefully-a place where healthy conflict leads to deeper community. A group of all leaders-each person becoming the maximum person he/she can be. $A$ spirit-a sense of peace and warmth comes over those who participate. ${ }^{108}$

\section{Practical Value of Small Groups}

Surveys that were conducted in the local churches in the United States reveal that small groups are valuable in a number of ways. For example, wherever there are small

$$
\begin{aligned}
& { }^{107} \text { Ibid., } 21 . \\
& { }^{108} \text { Ibid., 23-24. }
\end{aligned}
$$


groups, there are loving relationships of members getting involved in the running of the church, there is good church atmosphere, spirituality, and high standards, and the members care about unchurched people's conversion and spiritual gifts.

In small groups "there is loving relationship." ${ }^{109}$ Unlike a large congregation, members who are few in number pray together, confide in one another, and learn to trust one another. Members in small groups learn to love, care, fellowship, and experience change in their lives. Ted Haggard points out that when

Small groups work the way they are supposed to, people connect in a divine way with other people, and they begin to pray with other people, and they begin to pray for one another and care for one another in practical ways. Love connects them, wholesome, powerful, loving compassion and fellowship develop between these people, and those relationships touch other people. True change happens in people's lives. ${ }^{110}$

Small groups draw members into the life affairs of the church. New members will feel part and parcel of that church. For example, "As the church quickly involves new members in the life and ministry of the congregation rather than ignoring them, apostasy tends to drop." 111 Research has revealed that "unless the congregation gives a person a role in the church, a task to perform or a group to join, within one year he or she will likely become inactive. ${ }^{112}$

${ }^{109}$ Christian A. Swartz, Natural Church Development: A Guide to Eight Essential Qualities of Healthy Churches (St. Charles, IL: ChurchSmart Resources, 2000), 33.

${ }^{110}$ Ted Haggard, Dog Training, Fly Fishing and Sharing Christ in the $21^{s t}$ Century (Nashville: Thomas Nelson Publishers, 2002), 42.

${ }^{11}$ Roger L. Dudley and Des Cummings, Jr., Adventures in Church Growth (Hagerstown, MD: Review and Herald Publishing Association, 1983), 136.

${ }^{112}$ Ibid., 111. 
New members can leave or drop out of church, depending on the atmosphere in the church. There are different kinds of climates in churches. In a church where the climate is warm and friendly, new members stay. Small groups will effectively play a leading role in keeping the church warm and friendly. They do so because members who join small groups mostly live in the neighborhood. The new members are introduced to the church to join it or for baptism. Research has revealed that "where the member's rate climate in a church as warm and friendly, apostasies decrease." ${ }^{\prime 13}$

Members can drop out or stay in the church depending on the daily devotions of the members in their homes. Small groups can produce members who have a great desire to spend some time for devotions in their homes together with their families. It is said that the family that prays together stays together, so it is with the members that have devotions in their homes. In fact, research has shown that "in churches where a higher proportion of the membership has daily personal Bible study, we find fewer apostasies." ${ }^{.114}$

Members can drop out of the church or stay in the church depending on whether the standard of the church is perceived as high or low. When the new members find that the standard of the church is perceived as high in that church they will stay. Usually, they will not drop out or leave. Research has shown that "where

${ }^{113}$ Ibid., 137.

${ }^{114}$ Ibid. 
members perceive their church as holding high Adventist standards, usually we do not observe as many apostasies." 115

If small groups operate effectively in a church, spiritual gifts are more easily identified and developed:

Through relational dynamics of small groups, members become aware of each other's needs and respond to those needs. Gifts of encouragement, faith, prayer, leadership, etc., naturally manifest themselves. Members become involved in caring for each other during and outside of group meeting. It is difficult for anyone to hide or remain anonymous in a small group. ${ }^{16}$

Unchurched people with no church background are more easily won to a faith in Christ through evangelistic opportunities. Small groups fare better in evangelistic approaches and requirements than the traditional local church. It is interesting to note that "small groups meet the requirements better than most of our traditional approaches to evangelism. And if they can be linked with other evangelistic programs designed with contemporary society in mind (e.g., culturally relevant public evangelistic meetings and seminars, seeker services, different kinds of churches for different kinds of people), their evangelistic potential could prove to be unlimited."117

Furthermore, Cox says that people with no church background are more easily won to a faith in Christ because small groups can easily bridge cultural differences.

Churches are able to reflect fairly well the cultural mix of the community in which they worship ... but when the majority of the people reflect a different culture, the

\footnotetext{
${ }^{115}$ Ibid.

${ }^{116} \mathrm{Cox}, 44$.

${ }^{177}$ Ibid., 63.
} 
cultural "barrier" is an additional challenge. A small group offers a setting which is less threatening than a church building where small groups of people from different cultural or racial backgrounds can meet for the sharing of the Gospel and building of bridges across cultural divides. ${ }^{118}$

\section{Future of Small Groups}

The future of small groups in the church and organizations is in a central place. In most churches, small groups are breathing new vitality into the church. For example, Shaw says, "For the past twenty years, progressive churches have been strapping Small Groups onto their traditional structures. But the model that actually provides discipleship and numerical growth designs the rest of the church's structure around groups once they are in a central place."119 The meta-church structure, which includes small groups as primary are "in the center place." ${ }^{20}$ Carl George believes that "small groups will dominate numerically flourishing churches of the future. With the promise of superseding every system of care developed to date, the Meta-church is the most effective way to reach today's harvest and make disciples of Christ."'121

${ }^{118}$ Ibid.

${ }^{119}$ Mack, 55.

${ }^{120}$ Haydn Shaw, "Small Groups: The Shape of Things to Come," Visionary 6, no. 2 (1991): 4 .

${ }^{121}$ Mack, 56. 


\section{Summary}

In this chapter, theological foundations for small group ministry in the Bible, the writings of Ellen White, and in general literature have been discussed. Examples of small groups in both Old and New Testaments were reviewed. This is also true of church history, the writings of Ellen G. White, and general literature. Members in small groups will learn about love, honesty, and building of relationships. Members also learn about worship, building a relationship with God, service to those in need, and relationships through friendship evangelism.

Having covered theological foundations for small groups, we will now move on to discuss theoretical foundations for small group ministry in chapter 3. 
CHAPTER 3

\section{THEORETICAL FOUNDATIONS OF SMALL GROUP MINISTRY}

\section{Introduction}

This chapter briefly discusses theoretical foundations of small groups in the fields of social psychology, sociology, anthropology, and education. The chapter starts with definitions, a brief history, functions, types of groups, and ends with why groups are important.

\section{A Brief Survey of Current Literature in Psychology of Small Groups}

The study of small groups in the field of psychology reveals some important functions of small groups from a psychological perspective. For example, small groups serve as links to a higher organization and as aspects of human life.

Dennis Child defines psychology "as a systematic study of animal and human behavior (observable and mental processes) and covers all kinds of pursuits from making dogs salivate at the sound of the bell to a study of growth of intelligent behavior in human beings." In "1890 William James, the American philosopher and physician and one of the founders of modern psychology defined psychology as the science of mental life and

'Dennis Child, Psychology and the Teacher (New York: Continuum, 2004), 4. 
his definition provides a good starting point for our understanding today"2 Some of the branches of psychology are: physiological, social, developmental, clinical and counseling, and occupational psychology. As part of psychology, social psychology is the study of social institutions and their impact on the behavior of individuals, concentrating on external agencies, such as family, schools, committees, which influence people. ${ }^{3}$

The beginning of the study of psychology can be traced back to 1869 when Sir Francis Galton published a book, Hereditary Genius, in which he applied statistical procedures to the study of intelligence. This marked the beginning of the movement applying scientific and mathematical methods to the study of human behaviour, and made Galton the founder of psychological studies of individual differences. In 1879, William Hundt, a German psychologist, turned his scientific training to the study of psychology and established the first experimental laboratory. At the turn of the last century, Sigmund Freud tried to build a model of causes and cures of mental illness from careful observation of his patients (case study method) and thereby founded the school of psychoanalysis. ${ }^{4}$

There are several functions of small groups in social psychology. Social psychologists say that small group functions are related to the functioning of the larger. units of society. For example, "the institutional machinery of industrial, military, and educational settings reaches the individual through small groups of interacting personal associates. Small groups are the natural units of society regardless of its size, simplicity, and complexity.",

${ }^{2}$ Gillian Butler and Freda McManus, Psychology: A Very Short Introduction (New York: Oxford University Press, 1998), 1.

${ }^{3}$ Child, 5 .

${ }^{4}$ Ibid., 3 .

${ }^{5}$ Leigh Marlowe, Social Psychology: An Interdisciplinary Approach to Human Behavior (Boston: Holbrook, 1975), 430. 
Gillian Butler and Freda McManus point out that

as well as being an academic discipline psychology has many practical uses.

Academic psychologists are likely to specialize in one area of psychology, and to carry out research to further the science of life. Their findings help us to understand, explain, predict, or modify what goes on in the mind as a control centre for cognition, affect, and behavior (what we think, feel, and do) ${ }^{6}$

Different fields of psychology focus on different aspects of human life. For example, experimental psychology focuses on "primarily the subject matter of basic processes learning, memory, sensation, perception, sensory experiences are meaningfully, interpreted and acted upon."

Social psychologists "examine social cognition or thinking (including attitudes and impression formation), and social relationship (including aggression, helping, imitate, relationship, and group dynamics)." behavior are shaped by interactions with other people."

Psychology functions as an agent for social action and interaction. For example, "people may band themselves together for some purpose or social action. Many of the goals toward which an individual strives could not be reached except through joining

${ }^{6}$ Butler and McManus, 122.

${ }^{7}$ Ann L. Weber, Introduction to Psychology (New York: Harper Perennial Publishers, 1991), 12.

${ }^{8}$ Ibid., 13.

${ }^{9}$ Eric Landrum, Stephen Davis, and Teresa Landrum, The Psychology Major: Career Option and Strategies for Success (Upper Saddle River, NJ: Prentice Hall, 2000), 6. 
other individuals." ${ }^{10}$ Further, it has been observed that effective and meaningful interactions are successfully accomplished in small groups rather than in a crowd of people. "Most significant human interactions occur in small groups."

However, "small group studies in social psychology generally give more attention to interactions and their effects on individuals. Through the study of small groups, the behavioral scientist gains insight into more diffuse and more formal aggregations composing society."12

Psychologists say that small groups are found in all aspects of human life. There are "small groups in every society including family, preservation of culture groups, employment, politics, business organizations, training of the young, schools, and research."13 Small groups are essential for the survival of society. "It may be possible to live in an isolated manner on the fringes of groups, but our very nature cries out to be involved in a group. Groups primarily service individuals"14

In fact, Julie Gorman points out that the three

basic psychological drives are: inclusion, power, and affection. People have an inner need to be accepted by others, to belong to a group that is inclusion. People have an inner drive to not only be influenced by others but to powerfully influence others, in

\footnotetext{
${ }^{10}$ Marlowe, 431.

"Ibid., 430.

${ }^{12}$ Ibid.

${ }^{13}$ Gorman, 87.

${ }^{14}$ Ibid.
} 
exercising responsibility, in organizing and initiating. People want to like others and to be liked by them-that is, affection. Groups help us fulfill these three needs. ${ }^{15}$

\section{A Brief Survey of Current Literature in Sociology of Small Groups}

This brief survey of small groups focuses on the definitions, types, sizes, structure, boundaries, norms, interrelation, statues and roles, and reasons why people form small groups. The main small group types are: dyad, triad, primary and secondary groups, and associations.

Sociologists have defined sociology in several ways. Richard Schaefer defines sociology as "a systematic study of social behavior and human groups."16 Conrad Phillip Kottak defines sociology as "the study of evolutionary basis of social behavior."17 Rodney D. Elliot and Don H. Shamblin say that sociology is "a systematic scholarly discipline that seeks reliable, useful knowledge about human conduct, social relationships, groups, societies, and social change. It has developed several different theoretical perspectives and uses a variety of research methods." 18

There are several types of small groups in society, such as, dyad ( 2 people), triad ( 3 people), primary groups, secondary groups, associations, and societies. An example of

${ }^{15}$ Ibid., 88.

${ }^{16}$ Richard T. Schaefer, Sociology: A Brief Introduction, 5th ed. (New York: McGraw Hill Publishers, 2004), 431. 2000), 512 .

${ }^{17}$ Philip Conrad Kottak, Cultural Anthropology, 8th ed. (New York: McGraw Hill,

${ }^{18}$ Rodney D. Elliot and Don H. Shamblin, Society in Transition: A Humanistic Introduction To Sociology (Englewood Cliffs, NJ: Prentice Hall, 1992), 3. 
"the definition of a social group says that a group may be as small as two people. But a relationship between only two people is notably different from other social groups, as French sociologist Georg Simmel (1858-1915) pointed out many years ago. Simmel called a two person group a dyad (1950). Dyads make up the largest number of our relationships with other people and are the ones with most intense feeling-friendships, lovers, spouses, rivals, and enemies."19

The triad is a three-member small group where the third person can play a unifying role. Or employ a divide and rule tactics that unites two against one. "Thoreau said, I have three chairs in my house one for solitude, two for company, and three for society." You know from your own experience that the addition of a third person, forming a triad, fundamentally alters the nature and quality of interaction in a small group. The third person may seem an intruder or an outsider, or may serve as intermediary or moderator. The introduction of the third person often interferes with the intimacy desired by the people in a dyadic relationship. It does not matter as much if the group is four, five or six persons. It is the change from a dyad that constitutes a kind of quantum leap ${ }^{20}$

If a fourth person is added to the triad, it can no longer be called a triad. It will form a coalition. "As groups grow to the size of triads or larger, we can expect coalitions

${ }^{19}$ Elliot and Shamblin, 58-59.

${ }^{20}$ Ibid., 59. 
to develop. A coalition is a temporary or permanent alliance geared toward a common goal. Coalitions can be broad-based or narrow, and can take on different objectives."'1

Sociologists say that there are also two basic types of social groups, primary and secondary. A primary group has its members interacting for a long period of time in a highly personal, face-to-face manner. A typical primary group "then is relatively small in size, long lasting, involves intense and extensive interactions among participants, has a high degree of unity or cohesion and encourages intimacy in relationships. Examples of a primary group are a family, a play group of children, and an adolescent group..222 However, primary groups are "characterized by intimate face-to-face association and corporation. ${ }^{, 23}$ The "primary groups such as family are major socializing agents, especially in early years because they give newcomers their first exposure to the rule of life." 24

A secondary group is another basic type of social group according to Elliot and Shamblin,

A secondary group has some specialized purpose for being, rather than the generalized non utilitarian purpose of this primary group. In the secondary group people come together because they share some common interest or common goal and find it to their advantage to develop association with one another. Unlike the primary group, the secondary group does not encourage in-depth communication or intense interaction among the participants. People tend to relate to each other in terms of

${ }^{21}$ Schaefer, 121.

${ }^{22}$ Elliot and Shamblin, 59.

${ }^{23}$ Ibid.

${ }^{24}$ Joan Ferrante, Sociology: A Global Perspective (KY: Northern Kentucky University, Wadsworth Publishing Company, 1992), 133. 
their statuses and roles rather than as a "whole person." Relationships tend to be more superficial and less intimate than in the primary group. Secondary groups have less sense of unity, and the group is not as important as the members lives and identities. ${ }^{25}$

A "major distinction is made between primary and secondary groups. Primary groups are based upon personal intimate relationships. Secondary groups, which are more numerous in modern societies, are based upon less intimate status relationships."26

Sociologists have concluded that associations develop over time.

A college seminar group, for example, may start out as a secondary group, but after awhile it may become a primary group, or smaller primary groups may develop within it. All large groups, however, are secondary groups. These groups which are often called 'associations' include organizations such as business corporations, large factories, government departments, political parties and religious movements. Large secondary groups always contain smaller primary groups within them. Colleges and army camps for example, are secondary groups, but they may contain hundreds of primary groups. ${ }^{27}$

A society is defined as a type of small group that as a "group of people living in a given territory, who share culture and interact with people of that territory more than with people of another territory.,"28

Sociologists say that there are two sizes of small group organizations. These are a group of seven and a group of ten or twelve. Richard Schaefer poses this question:

At what time does a collection of people become large to be called a small group? That is not clear. If there are more than 20 members, it is difficult for individuals to interact regularly in a direct and intimate manner. But even in the range of 2 to 20

${ }^{25}$ Elliot and Shamblin, 60.

${ }^{26}$ Ibid., 84.

${ }^{27} \quad{ }^{27}$ Schaefer, 117.

${ }^{28}$ Ferrante, 484. 
people, group size can substantially alter the quality of social relationships. For example, as the number of group participants increases, the most active communicators become even more active relative to others. Therefore, a person who dominates a group of 3 to 4 members will be relatively more dominant in a 15person. ${ }^{29}$

Size of a group affects the life of a group. "Increased size affects group life in a number of ways. There is some evidence that larger groups (i.e., five or six members) are more productive than dyads and triads. Members of a larger group tend to offer more suggestions than members of smaller groups. There seems to be less agreement, but also less tension in such a group." 30

Sociologists discuss three main traits of small groups: patterned interactions, membership, and identity. Patterned social interaction is defined as "the way in which we respond to one another."31 Small group membership is also significant. "Members develop a feeling of togetherness, a sense of 'us' as opposed to 'them." "32 Groups "are made up of people, and in all but the most casual gathering, each member assumes certain statuses and roles defined by the group." ${ }^{933}$ The other "basic trait of a small group is

${ }^{29}$ Schaefer, 120.

${ }^{30}$ Niel J. Smelser, Sociology (Englewood Cliffs, NJ: Prentice-Hall, 1981), 116.

${ }^{31}$ Schaefer, 431.

${ }^{32}$ Ibid.

${ }^{33}$ Paul G. Hiebert, Cultural Anthropology (Grand Rapids, MI: Baker Book House, 1983), 182. 
identity." ${ }^{34}$ Furthermore, "to a great extent, groups provide people with their sense of individual identity, with awareness of whom they are and how they fit into the world." 35

As a result of interactions a group develops structure and forms boundaries, norms, interrelated statutes, and roles. The groups "involve intense and extensive interactions among participants, has a high degree of unity or cohesion and encourages intimacy in relationships ... individuals get their earliest and most basic experience of social unity. There is a fusion of individual and the group, subordination of interest of the individual to the interest of the group." ${ }^{36}$

According to sociologists, people form groups for several reasons. Following are some of them:

People form a groups for specific jobs to be done.

Many groups are formed to get a specific job done. These instrumental groups are needed to perform tasks that would be hard or impossible for a person acting alone. The job of a tank crew was to do battle in a Sherman tank, something none of the men could have done without others. The crew members were carefully recruited and formed into a group with a precise purpose. Looking further afield, we can see that this kind of directed, task-oriented group is common in social life. The construction gang, the assembly line, and the football team are all formed to achieve certain directed goals. ${ }^{37}$

People form a group for cooperation. "The social process in which groups of people work together to reach a common goal is called cooperation. When cooperating

${ }^{34}$ Ibid., 107-108.

${ }^{35}$ Ibid., 181.

${ }^{36}$ Elliot and Shamblin, 59.

${ }^{37}$ Smelser, 114. 
people accept the premise that their own best interest will be served by sharing the goal and the effort with others. Cooperation is a most fundamental social process and has been necessary for survival of individuals, groups and societies." ${ }^{38}$

Some form a group(s) because they want to socialize infants in their communities.

To humans group life is vital for socialization. Infants are dependent on adults for a long period of their lives. During this time they learn some of the skills and many of the attitudes needed to live in groups. As they grow older they absorb some of the knowledge, ideas, values, and rules of behavior of their group. Socialization makes them fit for social life and helps preserve the group beyond the life span of any of its members. But groups serve other functions besides socialization. ${ }^{39}$

People form small groups in their communities for expression. "In some groups (called expressive groups) the goal is to satisfy member needs for acceptance, esteem, and dependence. Such groups form spontaneously, with little outside influence. Examples include friendship groups and dormitory cliques."${ }^{.40}$

People form a small group because of the supportive role of the group.

People band together not only to perform tasks and meet social needs, but to relieve unpleasant feeling. In a class set of experiments Schachter (1959) used undergraduate students in "a waiting room" as subjects. Some of the subjects were given anxietyproducing information about the fictitious experiment that was about to take place. They were then asked to wait. A control group was just told to wait. These subjects had no basis for either pleasant or unpleasant feelings about the experiment Schacter asked all his subjects if they wanted to wait alone or with someone else. Confirming the adage that "misery loves company" members of the experimental group chose to wait with others more often than members of the control group. Schacter concluded

\footnotetext{
${ }^{38}$ Elliot and Shamblin, 63.

${ }^{39}$ Smelser, 115.

${ }^{40} \mathrm{Ibid}$.
} 
that groups reduce negative feelings by providing reassurance, distraction, and information. ${ }^{41}$

People form small groups to form into gangs for relationship:

We think of small groups as being informal and unpatterned yet, as interractionist researchers have revealed, they are distinct and predictable processes at work in the functioning of small groups. A long-term ethnographic study of street gangs in Chicago revealed an elaborate structure resembling that of family business. A street gang is composed of several geographically based unit sets, each of which possesses a leader, lower-ranking officer, and a rank-and-file membership. Besides staffing economic network of the drug trade, gang members develop relationships with tenant leaders in public housing projects and participate in non delinquent social activities important to the maintenance of their authority in the neighborhood. ${ }^{42}$

The study of decision making in small groups is important.

Decision making in a group rests upon the interaction of group members. Groups often require a degree of consensus or agreement before they will take an action. Also groups' being composed of a number of individuals leads them to have at their disposal a wider range of knowledge, expertise, and skills than is generally possible for a single individual. Thus groups have greater resources to draw on in making decisions than do individuals. ${ }^{43}$

When a group is confronted with a risk decision to make, it is felt that a small

group will make a less risky decision than an individual.

Stoner (1961) found that individuals in groups are often more likely to make risky decisions than are individuals acting on their own. This "risky shift" has been attributed to a "diffusion of responsibility"; individuals in a group can spread responsibility for a decision to all members of a group, and thus no single individual can be held accountable if the decision turns out to be wrong. This may

${ }^{41}$ Ibid.

${ }^{42}$ Schaefer, 120.

${ }^{43}$ Norman Goodman, Introduction to Sociology (New York: Harper Collins Publishers, 1992), 65. 
lead to bold but risky decisions that individuals might be reluctant to make on their own. Also the consensus building process of the group may stifle dissenters and decisions of the negative consequences of groups' emerging decision. ${ }^{44}$

Small groups form group networks where members of groups interact with other people, thus forming social networks.

Groups do not merely serve to define other elements of the social structure, such as roles and statuses; they also are an intermediate link between individuals and the larger society. We are all members of a number of different groups and through our acquaintances make connections with people in different social circles. This connection is known as a social network, that is a series of social relationships that link a person directly to others, and through them indirectly to still more people. Social networks may constrain people by limiting the range of their interactions, yet these networks may also empower people by making available vast resources. ${ }^{45}$

Finally, in small groups there are what is called a reference group where people feel that because they are members of this group they may evaluate themselves and their behavior.

Reference groups are used by people to formulate, compare, and evaluate their own behavior. Reference groups serve a normative function when they define appropriate behavior. A reference group may also serve a comparative function by providing either a model to imitate, or a standard, to judge the fairness of others' expectations of a person. A reference group may also serve an audience function by evaluating the adequacy of the person's behavior. ${ }^{46}$

There is a wide variety of small groups in any society, whether undeveloped or developed. Groups can help to solve problems and arrive at consensus decisions. Groups

${ }^{44}$ Ibid.

${ }^{45}$ Schaefer, 101.

${ }^{46}$ Goodman, 59. 
help to build and cement relationships, they promote unity and bind members of the group together. Small groups bring definition to culture.

\section{A Brief Survey of Current Literature in Anthropology of Small Groups}

This brief survey of small groups in anthropology discusses definitions, brief history, and kinds of small groups. There are several types of anthropology, including "cultural, archeological, economic, medical, biological and linguistic."

Paul G. Hiebert, in his book Cultural Anthropology, defines anthropology as "the study of people." ${ }^{248}$ Conrad Phillip Kottak defines anthropology as "the study of human species and immediate ancestors. ${ }^{, 49}$ Kottak also adds that "anthropology provides a scientific basis for dealing with the crucial dilemma of the world today; how can people of different appearance, mutually unintelligible languages, and dissimilar ways of life get along peaceably together?" 50 Thomas Hylland Eriksen defines anthropology as "a compound of two Greek words, 'anthropos' and 'logos' which can be translated as 'human' and 'reason', respectively. So anthropology means 'reason' about humans or

\footnotetext{
${ }^{47}$ Kottak, 505.

${ }^{48}$ Hiebert, 1 .

${ }^{49}$ Kottak, 28.

${ }^{50}$ Ibid., xi.
} 
knowledge about humans. Social anthropology would then mean knowledge about humans in societies."

Nigel Rapport and Johana Overing say that "anthropology had its birth as an academic discipline in the late nineteenth and early twentieth centuries, during what we might label the height of modern thought. Modernists and imperialists ways of thinking about things go deep, and since anthropology could be but the child of its time, the intellectual and political climate of those times is deeply implicated in its own development." E2 Eriksen confirms that "like other social sciences, anthropology is a fairly recent discipline. It was given its present shape during the twentieth century, but it has important forerunners in historiography, geography, travel writing, philosophy, and jurisprudence of earlier times. There are in any case many ways of writing a history of anthropology, just as in any given society there may exist competing versions of national history or origin of myths promoted by groups or individuals." ${ }^{.53}$

Among different ways of classifying human groups, "one approach would be simply to list all these groups alphabetically, but this overlooks the fact that there is a marked difference in the ways in which they are formed. Moreover the list would be large, it would be unmanageable." ${ }^{54} \mathrm{~A}$ second approach in classifying groups is to

\footnotetext{
${ }^{51}$ Thomas Hylland Eriksen, Small Places Large Issues: An Introduction to Social and Cultural Anthropology, 2nd ed. (Setering,VA: Plato Press, 2001), 2.

${ }^{52}$ Nigel Rapport and Joanna Overing, Social and Cultural Anthropology: Key Concepts (New York: Routledge, 2000), 10-11.

${ }^{53}$ Eriksen, 9.

${ }^{54}$ Hiebert, 178.
} 
construct a set of all combinations of human beings. For example, one might talk of all the people who are all five feet four inches tall, blond, blue eyed, and wearing size eight shoes or all men under thirty who have hunted crocodiles. But this leads to an infinite number of sets, most which are useless to the anthropologist and do not exist in the minds of the people involved. ${ }^{55}$ However, anthropology "like other social sciences is interested in forming generalization, which requires the reduction of unique experimental forms into broader categories." ${ }^{96}$

Anthropologists "frequently define groups of people on the basis of certain characteristics they have in common. One can speak of all those in a society who are over twenty-one, marry their cousins, are rich, or live along the Amazon river. These are statistical groups created by anthropologists for the sake of analysis, and the people in the group are generally unaware of their existence." ${ }^{.57}$ Hiebert says that "statistical groups can be extremely useful for analyzing a society, even though the people involved are not conscious of them. For example, the shoe manufacturer must know what percent of population has a given foot size." ${ }^{.58}$ However, "the critical test of statistical groups is not whether they exist in the minds of the people but whether they help the analyst to answer the questions he is asking about the society." 59

\footnotetext{
${ }^{55}$ Ibid.

${ }^{56}$ Ibid.

${ }^{57}$ Ibid., 178.

${ }^{58}$ Ibid.

${ }^{59}$ Ibid., 179.
} 
Unlike "statistical groups, which are essentially ettic in nature, societal groups are emic, they exist in the mind of the people. Franklin Giddings, a sociologist, has called the recognition that we belong to a group of people who are like ourselves in some ways 'consciousness of kind. ${ }^{60}$ Hiebert says that "people who are conscious of their common identity usually share certain visible signs, by which they recognize one another. These may be biological characteristics, such as age, sex, skin color, or body shape or they may be traits, like general styles of clothing, distinct accents and specific customs." ${ }^{\circ 1}$ However, societal groups are "the mental categories by which people sort out themselves and other human beings on the basis of similarity of kind. For example, Americans classify themselves politically as Republican, Democrats and Independents. Or they can be divided into Protestants, Catholic, Jews and so on. ${ }^{962}$

Hiebert says that "the 'social' implies interaction, and social groups are groups of people who associate and interact with one another. There are social groups of many kinds. For example, people riding a bus or cheering at a football game form a loose type of a social group.... Families and clubs are primary social groups, in which members interact in personal face-to-face relationships." ${ }^{.63}$ In fact "both societal and social groups have a consciousness of kind or identity. The difference between them is that members

${ }^{60}$ Franklin Giddings, Cultural Anthropology (Grand Rapids, MI: Baker Book House, 1983), quoted in Herbert, 179.

\footnotetext{
${ }^{61}$ Hiebert, 179.

${ }^{62}$ Ibid., 180-181.

${ }^{63}$ Ibid., 180.
} 
of social groups interact with one another, but not all members of societal groups do. For example, the Democrat party is a societal group, a mental category made up of great many people who have never met and in fact do not know that each other exists." ${ }^{94}$ Finaily, "both social and societal groups vary considerably in the extent to which they are formally organized. A group of Americans touring Europe together [a local group] may develop a sense of identity in the course of the month."

Anthropologists say that "Kinship Groups are sets of relatives of which we are a part, who know each other as individuals and who interact in some fashion as corporate group. For example; each individual has a circle of relation to whom he or she can trace definite genealogical and marriage ties; parents, grandparent, children, grand children, and a great many relatives descended from some common ancestor, as well as spouses."

Anthropologists define an association as "a group of people who have one or more interests in common. These interests are the group's functions, the purpose for which it was formed, and the range of such interests is as broad as culture itself. This can easily be seen by tabulating the clubs, committees, business, churches, and political parties found in as American town or city or the variety of association in which a typical college student may participate."

${ }^{64}$ Ibid.

${ }^{65}$ Ibid.

${ }^{66}$ Ibid., 224.

${ }^{67}$ Ibid., 244. 


\section{A Brief Survey of Current Literature in Education of Small Groups}

The brief discussion on small groups in education will involve definition, history, growth of small groups, small groups versus cooperative learning, cooperative learning, and the reasons for small groups in education.

There are several definitions of a small group in education. Kenneth $O$. Gangel and James C. Wilhoit define a Christian group as a "gathering of believers with mutual interest working toward a common goal."68 Joseph Luft defines a small group as "a living system, self-regulating through shared perception and interaction, sensing and feedback, and through interchange with its environment. ${ }^{169}$ Gerald Philip defines a small group as "a number of people adhering to a similar set of ideals or principles, or advocating a common goal though perhaps disagreeing about methods of achieving the goal, or sharing a common method of carrying on business, resolving conflict, or demonstrating awareness of each other." Robert Clark, Lin Johnson, and Allyn Sloat point out that "a small group can be a vital expression of God at work, fulfilling the need for community that he placed in the heart of His created beings."

Educators study events happening in the history of small group dynamics in education. Clark, Johnson, and Sloat say that Kurt Lewin is considered in the history of

${ }^{68} \mathrm{Kenneth} \mathrm{O}$. Gangel and James C. Wilhoit, The Christian Educator's Handbook on Adult Education (Wheaton, IL: Victor Books/SP Publications, 1993), 148-149.

${ }^{69}$ Ibid., 149.

${ }^{70} \mathrm{Ibid}$.

${ }^{71}$ Robert E. Clark, Lin Johnson, and Allyn K. Sloat, Christian Education Foundations for the Future (Chicago, IL: Moody Press, 1991), 508. 
small groups as the father of group dynamics in America. He was a Prussian from

Russia. He came to America in 1930. He studied "small groups-recognizing their value and their uniqueness for accomplishing purpose.... He founded a Research Center for Group Dynamics at Massachusetts Institute of Technology in 1946 opened the way for new studies that provided important insights for those who saw small groups process as a frontier for learning and personal response., 72

The church small group movement was accepted by the church in the 1950s and group dynamics became an acceptable science. This was embraced by such organizations as Campus Crusade, Navigator, Faith at Work, Yokefellow, and others. These organizations were led by Sam Shoemaker, Elton Trueblood, and others.

Church awareness of the deliberate cultivation of this process occurred in the 1950s. The educational arm saw value in incorporating group dynamics as an acceptable science, and utilized methodological insights to increase the effectiveness of Bible study in groups. The element of the church most receptive to acceptance of these humanly observed patterns to teach divinely inspired content was the parachurch sphere. Enthusiastic embracing of small groups by such organizations as InterVasity, Campus Crusade, Navigators, Faith at Work (Sam Shoemaker), Yokefellow (Elton Trueblood), and others did much to establish it as a credible movement. ${ }^{73}$

During the 1960s, in a time of social issues, the focus of small groups in America shifted to questions of renewal and reality both in the inner person and the world at large. Among the persons of influence were Keith Miller, Bruce Larson, Gordon Crosby, and Elizabeth O'Connor.

The decade of the 1960s in this country was the time of acting out concerns over social issues. Christendom felt this influence, and the small group focus shifted to

\footnotetext{
${ }^{72}$ Ibid.

${ }^{73}$ Ibid., 508-509.
} 
questions of renewal and reality of both in the inner person and in the world at large. Influences who marked this period include Keith Miller and his Taste of New Wine, the transparency of Bruce Larson of Faith at Church of the Savior, Washington, DC influenced by Gordon Crosby and Elizabeth O'. Connor's Call to Commitment, and the Pittsburgh Experiment. (The Pittsburgh Experiment was an attempt by lay persons to integrate their faith with the business and work world). ${ }^{74}$

In the 1970s the small group focus became person-oriented. Secular writers of influence were Carl Rogers, Fritz Pearls, Eric Berne, Thomas A. Harris, and Sid Simon.

When the "cause" was exchanged for the inner focus of the "me" generation of the 1970 s, small group focus became person oriented. Growth was seen as prompted by inner examination and awareness of personality traits. Secular writers such as Carl Rogers, Fritz Pearls, Eric Berne (Games People Play [New York: Group Press, 1964]), Thomas A. Harris (I'm OK, You're Ok [New York: Harper \& Row, 1969]), and Sid Simon on value of clarification (see I. Rath, M. Harmin, and S. Simon, Value and Teaching Working with Values in the Classroom ([Columbia, Ohio: Charles Merill, 1961]) helped fuel this emphasis. The result was that small groups became primarily focused on "What is happening to me in this group"? 75

Many new materials were developed in small groups for use in Bible studies, social action, and personal growth. Lyman Coleman, "a pioneer in the development of materials for church small groups, sees the 1980s as a period of integration. The focus of groups moved to balance incorporating all three of the previous focuses: Bible study, social action, and personal growth. This multifaceted approach matched the wholistic emphasis of the 1980s culture?"76

Between the 1960s and 1970s small groups in the church became part of the organized church structure and, as a result, small groups in the United States flourished

\footnotetext{
${ }^{74}$ Clark, Johnson, and Sloat, 509.

${ }^{75}$ Ibid.

${ }^{76}$ Ibid.
} 
and became the center of ministry in the church. "Although small groups of the 1960s and early 1970s existed primarily outside the institution of church structure-and often in reaction to it-in the late 1970 s and 1980s small group ministry became a part of organized church structure-even at the center of that ministry. Organization experts in the propagation and refining of church small groups flourished." 77

Apart from what was happening in education and the promotion of small groups by individuals, organizations, and churches, the church growth movement was involved in the promotion of small groups as well. Furthermore, to add to what was happening in the promotion of small groups by church growth movements, both Fuller Seminary and the Institute of Church Growth not only promoted small groups but involved laity in their evangelistic endeavors:

In addition to widespread influence of Serendipity, the church growth movement became a strong promoter for the development of small groups in the creation of a healthy church. (Serendipity is an organization begun by Lyman Coleman to foster and equip small group ministries. Located in Littleton, Colorado, this group has been the driving force behind thousands of seminars and has produced numerous curricular aids for small groups.) Both the Church Growth Institute of Fuller Seminary and the American Institute of Church Growth became centers for influencing the use of this means for evangelizing and unleashing the laity. ${ }^{78}$

However, despite the growth of small groups in certain parts of the world, there are causes for the general receptivity towards small groups today. Some of them are loss of former networks of community, breakdown of the nuclear family, increase in distance between members of extended families, and divorce. There are many causes for a general

${ }^{77}$ Ibid.

${ }^{78}$ Ibid., 509-510. 
receptivity towards small groups today. "In general there has been a loss of former networks of community. Primary among these losses has been the breakdown within the nuclear family and increasing distance between members of extend families. Divorce and other family fractures have produced insecurity and instability, damaged self esteem, and created mistrust and fear of relationships." ${ }^{979}$

Regardless of "the breakdown within the nuclear family and increasing distance between members of extended families, ${ }^{, 80}$ small groups are still popular in most communities in the world for

new technology has broadened the definition of groups to include those who interact electronically. Not all the 'people' with whom we converse online are real. At the same websites chatterions dectitious correspondents created by intelligent programs respond to questions as if a human were replying. While answering product or service-related questions the chatterbot may begin chatting with online customers about family or weather: ${ }^{81}$

There are great varieties and purposes of groups in education. Clark, Johnson, and Sloat agree that there is "great variety in small groups today. All of them, regardless of their uniqueness, share three purposes in common: (1) to meet the needs of the person in the group, (2) to accomplish the purpose or task, and (3) to maintain group relationships to such an extent that the members choose to act in cohesion rather than on their own.

\footnotetext{
${ }^{79}$ Ibid., 510.

${ }^{80}$ Ibid.

${ }^{81}$ Schaefer, $100-101$.
} 
The fact that people's needs, purposes, and relationships are so different mean that the groups produced will also reflect this wide scope of differences." ${ }^{92}$

Small groups are effective and use practical methods in the teaching and learning process. "Today within the education field there is a strong movement towards using small groups as a more effective method in the teaching and learning process. Much of what has been written is placed in the arena called 'Cooperative Learning.' There have been over a thousand studies on the benefits of cooperative learning in support of the use of small group methods." ${ }^{\prime 3}$ Cooperative learning "is a term used for a style of learning that is focused on groups as opposed to learning from competing with others and the outcome is on 'survival of the fittest' not on cooperation. Researchers, however, for decades have been building a stronger argument that competition tends to develop people skills in a more productive way. $" 84$

One example of cooperative learning that Donald James quotes in his dissertation on cell-based ministry is that "cooperative learning through small groups is being used with great success where educators are using TRIBES. TRIBES is an organization that has not only tapped into the discipline of Cooperative Learning but also focuses on brain compatible learning, multiple intelligence, and social development research. The

${ }^{82}$ Clark, Johnson, and Sloat, 514.

${ }^{83}$ TRIBES: A New Way of Learning and Being Together, Reaching All Students: Tribe Learning Communities, 2, http://www.tribescom/reaching_all_students.htm (accessed 21 March 2005).

${ }^{84}$ Philip O’Neil, "People Mixing," http://www.peoplemixing.com (accessed May 11, 2005); C. Partunder, Cooperative Learning Center, "What Is Cooperative Learning?" The University of Minnesota, http://www.cooperation.org (accessed May 11, 2005). 
TRIBES process in education has developed in many communities a positive culture for learning and human development. The American Education Research Association awarded the school district of Beloit's TRIBES study with a year's top evaluation of an instructional program.

Reports from schools using "TRIBES show at least 75 percent reduction in behavior problems, dramatic decline in school violence, and increases in academic achievements with inner city schools. TRIBES as studied by Research Triangle Institute under a U.S. Department of Education grant, was cited as a model program to teach students social skills (first grade-high school), and for use in special education classrooms. ${ }^{186}$

Another example that Donald James talks about is that cited by Jeanne Gibbs in her A New Way of Learning and Being Together, where she says "At best, traditional teaching gives each student about five to ten minutes a day for discussing academic topics or responding to the teacher. In contrast, in small groups dialogue with peers provides ten times from what they get under traditional teaching methods. At the same time, students are learning how to work with the use of collaborative skills." ${ }^{87}$

There are several reasons for learning in small groups in education. Small groups learning in education benefit the student or the small group member because the

\footnotetext{
${ }^{85}$ TRIBES: A New Way Of Learning and Being Together, "Announcements," htttp://www.tribes.com/announcements_new_material.htm (accessed March 21, 2005).

${ }^{86}$ TRIBES, "Reaching All Students," 2.

${ }^{87}$ Jeanne Gibbs, TRIBES: A New Way of Learning and Being Together (Windsor, CA: Center Source System, 2001), 20.
} 
individual will have his or her needs met. It is important that people have various needs that lead them to join the small group or groups. In education, it is possible for small groups to satisfy the needs of an individual, as long as they are made known to the members of the group. Clark, Johnson, and Sloat say, "The most prevalent need that drives an individual to bond with others is the satisfaction of some personal need. This may be a desire for experiencing a supportive climate among equals. It may be stimulation or growth. For others there is simply the desire to make friends and to have a sense of belonging." ${ }^{98}$

Individuals find acceptance and care in small groups. Children or adults will find that they are accepted by the other members of the group. The members not only accept them, they also provide care. When they join the group, every member of the group indicates their willingness to help wherever help is needed. New members in the community or church or school are always anxious to make new friends and settle down. The small group members will provide acceptance and care. Clark, Johnson, and Sloat have written:

Groups become structures of hope. In a sense the modern day small group serves as a city of refuge for those drained by the stress and debilitating situations of life. While the church can declare itself a place of acceptance and care, it is often within the small group structure that claim is realized. Of particular note today are supportive groups for those affected by a dysfunctional situation affecting their lives. Popular for not only acceptance but also their practical help are groups on divorce recovery, abuse, terminal illness, chemical dependency, work-a-holism, and so on. ${ }^{89}$

\footnotetext{
${ }^{88}$ Clark, Johnson, and Sloat, 513-14.

${ }^{89}$ Ibid., 512.
} 
Another important benefit of learning in small groups is that there is greater incorporation and formation of individuals who join the small group. The individual finds it easier to be assimilated into the group. He or she can quickly start to participate in the group's activities and learn to gain insights as they listen to others speak. Clark, Johnson, and Sloat observe that persons are effectively assimilated and discipled in the faith through group structures that allow them to participate interactively. Declaring and discussing an understanding of the faith is a necessary experience for incorporating new aspects of faith that enhance or alter previous convictions. Members gain insights from hearing others in the group declare what it means to them to understand and apply what is believed. The values described in the Scriptures must be learned in relationship. ${ }^{90}$

Lawrence O. Richards declares that to learn trust, love, and to become loving, all must be involved. He says,

To learn to trust, and to become trustworthy-to learn to love, and to become loving-we must become deeply involved in the lives of others, to who we consult ourselves in Christ. To develop this kind of relationship we need to share ourselves with others, and they need to share themselves with us. All of this demands time. More than this, it requires a face-to-face relationship. A relationship we can have only with a few others at one time. And thus a church is forced to move to small group structure. ${ }^{91}$

Furthermore, other benefits of small groups in education involve task achievement. People can achieve much more of a task in a group than as an individual. There is also the sustaining power and complementary contributions of many for the

${ }^{90}$ Ibid.

${ }^{91}$ Lawrence O. Richards, A New Face for the Church (Grand Rapids, MI: Zondervan Publishing House, 1991), 153. 
completion of the task. Clark, Johnson, and Sloat say, "Corporate units can often accomplish what individuals cannot do alone. A major benefit of groups is the sustaining power and complementary contributions of many for the completion of the task-whether that task be learning information, feeding the homeless, or bringing to fruition a vision. ${ }^{.92}$ Mallison states that Fidel Castrol declared, "I began my revolution with 82 men. If I had to do it again, I would do it with 10 or 15 men and absolute faith. It does not matter how small you are, provided you have faith and a plan of action, ${ }^{, 93}$

Small group benefits in education include raising the individual's level of selfesteem, confidence, belonging, and intimate environment for change.

Small groups also improve the ability of the individual for decision making, and prompting change because of participation. Overall good small groups raise a person's level of self esteem and confidence as persons contribute to the group and feel a sense of belonging. This atmosphere provides a safe, intimate environment for change. Certain methods of group discussions and decision-making appear to be more effective than information giving in prompting change, because interactive participation adds attitude awareness and of value and mission. ${ }^{94}$

Small groups "provide models of how to live peacefully with others. This is difficult in places where people are crowded in today's over populated towns and cities. Another asset of small groups is that they provide a model for how to live biblically with others in the family and in the church at large. Seeing concepts enfleshed makes them transferable." 95

\footnotetext{
${ }^{92}$ Clark, Johnson, and Sloat, 513.

${ }^{93}$ Fidel Castro, quoted in Mallison, 4.

${ }^{94}$ Clark, Johnson, and Sloat, 513.

${ }^{95}$ Ibid., 514.
} 


\section{Why Small Groups Work in Psychology, Sociology, Anthropology, and Education}

Though small groups seldom make headlines, they work in the above fields of human endeavor because they are useful, beneficial, attractive, and supported in literature. ${ }^{96}$ Donald James points out that "small groups today are seen to be useful in a variety of situations. ${ }^{.97}$ For example, small groups are useful in teaching and in the learning process in education, in behavior in psychology, in building relationships in sociology, and also in community cultural building in anthropology. Further, James affirms that small groups have benefits to both individuals, community, and organizations because the small groups "contribute to an understanding of how humans benefit from being in a group by fulfilling three basic psychological drives which are inclusion, power, and affection.. 98

James continues to say that small groups are attractive to many people because of what Robert Wuthnow has stated in his article in Christian Today: That "groups are beginning to alter American society, both by changing our understanding of community and by refining our spirituality"99 Further, James agrees with Wuthnow, who writes that:

\footnotetext{
${ }^{96}$ Donald James, Cell-Based Ministry (Berrien Springs, MI: Andrews University Press, 2005), 31.

${ }^{97}$ Ibid.

${ }^{98}$ Ibid.

${ }^{99}$ Robert Wuthnow, "How Small Groups Are Transforming Our Lives, Christianity Today, February 1994, 2, http://webinfotrack.galegroup.com/itw/inform684/ 805/ 64860609w4/purl=rcl_GRGM (accessed 23 March 2005), quoted in James, 42.
} 
Small groups are attracting people on an unprecedented scale and are affecting the ways we relate to each other, including how we relate to God. Many people are saying that their identity has been changed by being a part of the small group. Groups are providing a strong sense of community, which has always been the major aim of most groups. Many people feel that their faith has been deepened. Groups have helped broaden the experience and choices in the life of many, and faith seems to be more fluid with greater freedom to choose the religion of one's choice. Small groups are succeeding because they are going with the flow of meeting the needs of humankind. ${ }^{100}$

Small groups work in spite of making few headlines. For instance, "even though mass media defines what is important, it seems to easily dismiss the small group phenomenon. However, to overlook the trend would be a serious mistake, for the small group movement has been affecting a quiet revolution in American society. Its success has astounded even many of its leaders." group is without a doubt one of the most powerful tools of life change and spiritual growth." 102 The evidence of behavioral sciences, etc., supports the affirmations of the Bible and writers of small group literature.

Small groups work in education in organizing the class and the classroom. In organizing the class and the classroom for both children and adults, Andrew Pollard and Sarah Tann say, "People in a classroom need to be organized in ways which are most appropriate for supporting learning activities which have been planned. Obviously this
${ }^{101}$ Ibid.
${ }^{101}$ Ibid., 43.
${ }^{102}$ Cloud and Townsend, 14. 
involves children but, in many classes, it also involves adults such as ancillary staff." ${ }^{103}$ They also point out that in education group-work, "it is often recommended for developing social and language skills and as a means people can support, challenge and exceed their learning together (e.g., through problem solving or work on a creative task.) $" 104$

This chapter briefly discusses theoretical foundations for small groups in social psychology, sociology, anthropology, and education. The focus in social psychology is on definition and functions of small groups, while in sociology the chapter looks at definition and types of small groups. As for anthropology, the focus is on definition and types of groups. Finally, the chapter briefly discusses history, reasons for small groups in education, and why small groups work in psychology, sociology, anthropology, and education. We turn now to the church growth patterns in the North Zambia Field.

${ }^{103}$ Andrew Pollard and Sarah Tann, Reflective Teaching in Primary Schools: A Handbook for Classrooms, 2nd ed. (Trowbridge, Wiltshire, England: Redwood Books, 1993), 185.

${ }^{104}$ Ibid., 186. 


\section{CHAPTER 4}

\section{CHURCH GROWTH PATTERNS IN THE NORTH ZAMBIA FIELD}

\section{A Brief History of the North Zambia Field}

This chapter presents a brief history of the local people and their cultural beliefs and practices. It introduces the pioneering Adventist missionaries who started Musofu and Chimpempe Mission Stations in the North Zambia Field. An overview of evangelistic strategies and membership growth is presented.

\section{People}

The North Zambia Field in Zambia occupies two provinces, the Luapula Province (population of 928,924 people) and the Northern Province (population of 1,516,825 people).

The largest tribe in the Northern Province are the Bemba. ${ }^{2}$ There are also other smaller tribes, including the Mambwe, ${ }^{3}$ Namwanga, Lungu, and Tumbuka peoples.

\footnotetext{
${ }^{1}$ Seventh-day Adventist Church Website of the North Zambia Field, http://www .adventiststatistics.org/view (February 24, 2006).

${ }^{2}$ Seventh-day Adventist Encyclopedia, 1976 ed., s.v. "Bemba."

${ }^{3}$ Languages of Zambia for 2000-2001, www.enthologue.com (February 20, 2006), 53.
} 
The Lungu, Namwanga, and Mambwe tribes speak different languages because their ancestors came from Tanganyika (Tanzania). The Tumbuka people speak Chitumbuka, a different language because their ancestors intermarried with the Ngoni and the Zulu people who came from South Africa led by King Zwangwendaba.

The Bemba tribes that live in Luapula Province are the Lunda, the Chishinga, the Bwile, and the Baushi, who "occupy the valley of Luapula River in what is now Luapula Province." All these tribes speak the Bemba language. In this dissertation "Bemba" will refer to all the people in the Northern and Luapula provinces because of their cultural commonality.

The Bemba tribes in both provinces are subsistence farmers and fishermen who use the chitemene system (slash and burn) for fertilizing the soil. The Tumbuka, Namwanga, Mambwe, and Lungu in the Northern Province keep cattle for their livelihood. ${ }^{5}$ The tribes have a traditionally organized form of government under the umbrella of the national government. Each tribe has its own chief who is the head of the tribe. He is assisted by assistant chiefs and headmen. The senior chief is chairman of the tribal council. The assistant chiefs and headmen are members of the Chief's Governing Council. The business of ruling the tribe is vested by the national government in the chief

${ }^{4}$ Anne M. Bliss and J. A. Rigg, World Bibliography Series, vol. 51 (Oxford, England: Clio Press, 1984), 52.

${ }^{5}$ Ibid. 
and his council. Order is always observed strictly by people in the tribe. The chief and his council have a final say on matters pertaining to the affairs of his people. ${ }^{6}$

When the missionaries were establishing churches and schools, the District Commissioners of the British Colonial Government sent them to the chiefs in the areas to obtain permission to buy land in their areas. As long as the chief and his people were willing to welcome the missionaries into their territory, the British Government gave them the go-ahead and allowed them to settle and operate in Zambia.

\section{Beliefs}

Traditional beliefs and practices of the Bemba had many points of contact with Christianity. This explains why it was not difficult for the early missionaries to find converts among the Bemba people. It was easy to convert them to Christianity because of several central beliefs. The Bemba people believe in (1) one Creator God, and (2) four classes of spirits.

First, the Bemba people believe in the existence of the supreme God, called Lesa. "It is not easy to understand their idea of God. Sometimes he is regarded as a natural force. When lightening flashes and thunder roars, they often refer to it as God being angry or talking. He is also known as Kabumba, that is, Creator. He controls nature but remains remote from human affairs."

${ }^{6}$ The details come from the author's personal knowledge. He was born in Luapula and worked in the Northern Province.

${ }^{7}$ Cornelius M. Matandiko, Seventh-day Adventism in Zambia (Lusaka, Zambia: Zambia Adventist Press, 2003), 14-15. 
The Tumbuka people believe in Chiuta, as do the Namwanga, Lungu, and Mambwe. Tumbuka religious beliefs are like those of the Bemba people, for they believe in a supreme God like Chiuta. He is "the great-one of the bow." "Chiuta is used within the Christian religious context to refer to God." This God is known as "the creator and master of life and death."10

Second, the Bemba people also believe in four classes of spirits. The shamfumu are ancestral spirits (spirits of dead chiefs and village leaders that exist in animal forms like snakes or lions). There "are cases where big snakes were sighted, that where wearing strings of beads. It was forbidden to kill such creatures which were venerated and often referred to as shamfumu, that is a chief." I1 It said that these "royal ghosts who may choose to appear in any form, have power over fertility of the land."12

The Bemba people also believe in Ingulu, the spirits of elders or medicine men, who died with the desire to perpetuate their healing or divination through someone living. They enter the body of one who begins to behave and talk like the deceased, and to prophesy. ${ }^{13}$ Douglass Werner adds, "Besides making prophesies and finding medicines,

${ }^{8} \mathrm{E} . \mathrm{H}$. Wendland, Of Other Gods and Other Spirits (Milwaukee, WI: Northwestern, 1977), 11.

${ }^{9}$ Hiroshi Obayashi, Death After Life: Perspectives of World Religions (New York: Greenhood, 1992), 11.

${ }^{10}$ Donald Fraizer, Winning a Primitive People (Westport, CT: Negro College University, 1970), 120.
"Matandiko, 15.
${ }^{12}$ Ibid.
${ }^{13}$ Ibid. 
these go into trances, dance and make witchcraft accusations."14 The Baushi people, apart from believing in the Creator God, also believe in Makumba (god of the earthquake or tremor) as one of the Ngulu (spirits).

The Imilung $u$ are nature spirits often entreated to send rain and fertilize crops. ${ }^{15}$ They reside in mountains, hills, and rivers. Since these spirits are not of the local people, they had their own foreign names, which were given to people they possess. They are believed to be inhabitants of various countries. ${ }^{16}$ "Although they are not spirits of the dead, they can cause death if not placated."17

The Ifibanda (sometimes these are known as Ifiwa) are plain evil spirits, arising from bad people, such as wizards, after they die. They are feared as malevolent and they cause sickness and death. Most religious rituals are aimed at preventing the evil and averting the displeasure of harmful or potentially harmful forces, which are these spirits. ${ }^{18}$

When it comes to death, the Bemba people conduct various rituals until a time when the dead are elevated to ancestral spirits. "Isambo lya $m f w a$. This is when the surviving spouse or a very close relative to the deceased explains in detail, step by step the beginning of sickness to death. The spouse explains what his or her role was and the

${ }^{14}$ Douglass Werner, "Some Development in Bemba Religious History," Journal of Religion in Africa 4, no. 1 (1971): 21.

${ }^{15}$ Gullen Gouldsbury and Herbert Sheane, The Great Plateau of Northern Rhodesia (New York: Negro College University, 1969), 82.

${ }^{16}$ Robert Andrew, $A$ History of the Bemba (Madison, WI: University of Wisconsin, 1973), 76.

${ }^{17}$ Matandiko, 15.

${ }^{18}$ Brian Carvey, Bemba Land Church (New York: Brill, 1994), 16. 
effort done to bring the sick to health." 19 A second ritual then follows a few days after burial when another important meeting is convened. This ritual is known as "kufwika imishingo: that is inheriting the name. Here relatives meet to discuss who would be the most suitable among the nephews and grandchildren to be named after the deceased."20

After the name transfer ritual comes the ukuwamya or kusukula ichiwa, "cleansing." This ritual calls for sexual intercourse to eliminate the destroying spirit. Until the surviving spouse has been 'inherited' through sexual intercourse, such a union with any other is held to be dangerous and remarriage is out of question. If a suitable person is not found, or if the bereaved refrains for moral reasons, a child is made to sit on the lap of the bereaved to rub impemba (white powder) in the hands saying, "Be free of our relative ghost." ${ }^{21}$

Then after several months comes the ukupyanika (that is inheritance) ritual. "At this time, they remove the mourning clothes from the widow/widower. At the same time, the relatives may decide to give a new spouse to care for children and even take over conjugal rights."

Finally, one year after the death comes the "ukupupa that is 'remembrance' ritual. At this ceremony individuals prepare food and beer for a feast known as ichikoloti. This is a form of remembrance when the mourning period is called off and the dead are called

\footnotetext{
${ }^{19}$ Matandiko, 30.

${ }^{20}$ Ibid.

${ }^{21}$ Ibid., 31 .

${ }^{22}$ Ibid.
} 
back to participate in social functions of the community. At this time the dead are elevated to the status of ancestry. They can be consulted and appeased."23

The Lungu, Namwanga, and Mambwe "believe in the existence of gods for rain, fertility of the soil, and luck. They believe in Mwizya, Kapembwa, and Chizya.,24 Their rituals for inheritance after the death of the spouse and life after death are similar to the Bemba.

When the missionaries went to Luapula and the Northern Provinces to spread the gospel of Jesus Christ, these (and some others) were the local beliefs and rituals that confronted them. Some of the beliefs and rituals they could change or discourage using, but some were not easy to change or discourage. It is interesting that when the Gospel was preached, the Spirit of God moved and good numbers of people were converted and baptized at various places wherever missionaries went looking for converts, opening churches and schools, and building healthcare centers.

\section{Missionaries}

After the travels of Dr. David Livingstone, which started in $1853,{ }^{25}$ and other pioneers, Northern Rhodesia (Zambia) was opened for settlement by the British

${ }^{23} \mathrm{Ibid}$.

${ }^{24} \mathrm{Mrs}$. Nanyangwe, an elderly Mambwe lady, interviewed by researcher, August 5 , 2006.

${ }^{25}$ Bliss and Rigg, 37. 
Government. Large numbers of missionaries ${ }^{26}$ came to Zambia to spread the Gospel of Jesus Christ in this new territory. The Northern Province was opened up for missionary activities mostly by the Roman Catholic Church and Presbyterian Livinstonia Missionaries at Mwenzo in 1894. In 1895, the Roman Catholic Church fathers settled in the Kasama and Mbala districts, while the Presbyterian Livingstonia Missionaries settled in the Chinsali and Isoka districts. ${ }^{27}$

In the 1890 s the western and southern parts of Luapula Province were entered by London Missions Society missionaries at Mbereshi, Mansa, Lwela, Chembe, and Samfya Mission Stations. They also started missionary activities in Chief Mailo's area in Serenje district under Robert Moffat, and at Siwangandu where Sir George Brown settled. In these areas missionaries were recognized as being authorized to open churches, schools, and hospitals. It is overwhelming that chiefs and their people in Luapula Province were both eager to allow their people to be educated and to join new churches in their areas. ${ }^{28}$

In the northern, central, and eastern parts of Luapula Province, the missionary activities were conducted by Seventh-day Adventist Church pioneers, the Catholic Church, the Christian Missions in Many Lands, and the London Missions Society

26 "History of Church Activities in Zambia," www.en.wikipedia.org/wiki/Historyof-Church-Activities-in Zambia (accessed March 24, 2006).

${ }^{27}$ Ibid.

${ }^{28} \mathrm{Ibid}$. 
missionaries. Each of these Christian mission entities was organized around the chiefs or village headmen whenever permission was granted by the chief of the area. ${ }^{29}$

The Seventh-day Adventist pioneers opened churches and schools in the north and central parts of Luapula Province at Chimpempe village in Chief Kabanda's area, Lifuka Village in Chief Kazembe's area, Kawambwa in Chief Munkanta's area, Mununga in Chief Mununga's area, Ponde in Chief Puta's area, Kasheta in Chief Mununga's area, Lupiya in Chief Chipungu's area on the shore of lake Mweru and at Mansa in Chief Chisunka's area. They also settled at Samfya in Mwanfuli's village under Chief Kasoma Bangweulu. The headquarters for the work in Luapula Province was based at Chimpempe Mission Station where the director lived. The work in Luapula spread to all parts of Luapula Province. Currently the headquarters of North Zambia Field is at Mansa which was chosen for its centrality in $1972 .^{30}$

\section{Zambia Field}

The history of the establishment of the Seventh-day Adventist Church in the North Zambia Field starts in 1903 with the opening up of missionary activities in Zambia at Rusangu near Monze in the Southern Province by "using Solusi Station in (Southern) Rhodesia, as a base. W. H. Anderson, Jacob Detcha (who could speak the Tonga language), and several African workers set out for Northern Rhodesia (Zambia) for a

\footnotetext{
${ }^{29}$ Ibid.

${ }^{30}$ Tbid.
} 
possible mission site." When they arrived in "Northern Rhodesia in Chief Monze's area, Chief Monze granted them a 5,436-acre (2,200-hectare) plot of ground, which became to be Rusangu Station."32 "On July 1, 1905, a group of workers, including W. H. Anderson and his family, Jacob Detcha, Philip Malomo, Jack Mahlatini Mpofu and Andrew Nyakana arrived to open the station"33

Musofu Station in Chief Chitina's area in the Copperbelt Province was started in 1917 by "S. M. Konigmacher who left Rusangu to open work in the Chitina area not far from the town of Ndola." ${ }^{34}$ Chimpempe Station in Chief Kabanda's area in Luapula Province was begun in September 1921, with the arrival of H. I. Hurlow and two African workers, Lawson Endaenda and Isaac Galwele.,"35

The influence of the Seventh-day Adventist Church began at mission stations with the opening up of schools and healthcare clinics. It later expanded to other provinces of Zambia, such as the Copperbelt and Luapula Provinces. This expansion of church activities ignited a membership explosion in the 1960s in Northern and Luapula Provinces in Zambia. ${ }^{36}$

\footnotetext{
${ }^{31}$ Seventh-day Adventist Church Encylopedia, 1996 ed., s.v. "Rusanagu."

${ }^{32}$ Ibid.

${ }^{33}$ Seventh-day Adventist Church Encylopedia, 1996 ed., s.v. "Workers." ${ }^{34} \mathrm{Ibid}$.

${ }^{35}$ Seventh-day Adventist Church Encylopedia, 1996 ed., s.v. "Chimpempe."

${ }^{36}$ Seventh-day Adventist Church Encylopedia, 1996 ed., s.v. "Schools and Clinics."
} 


\section{Musofu Mission--1917}

Evangelization of the north by the Seventh-day Adventist pioneers began at Musofu Village in Chief Chitina's area, in the Copperbelt Province of Zambia. The pioneering work at Musofu in the Copperbelt Province was started by S. M.

Konigmacher in 1917 . He opened a school which grew very fast so that by 1920 there were 131 students at Musofu Village school. He also opened a church there. S. M. Konigmarcher worked with Matthew Chiwanga, a local man who was converted to Adventism and was trained as a leader and minister in the Lamba land. S. M. Konigmarcher started a church and established a school at Musofu Village in Chief Chitina's area in 1917. In 1993 the school had 15 teachers and 500 students. $^{37}$

\section{Chimpempe Mission--1919}

Further north in Luapula Province, the work at Chimpempe Village on the Kalungushi River, in Chief Kabanda's area, was started as a result of the pioneering activities of J. C. Rogers in 1914, W. E. Straw and J. N. de Beers in 1919, and H. J. Hurlow in 1921, accompanied by two national workers, Lawson Endaenda and Isaac Galwelle. $^{38}$ They organized a church of 26 members in 1927, opened a school, dispensary, workshop, and built cottages for national teachers by $1929 .{ }^{39}$ From

${ }^{37}$ Ibid., 939.

${ }^{38}$ Ibid.

${ }^{39}$ Ronald Charles Lloyd Thomson, "History of the Growth and Development of the Seventh-day Adventist Church in Southern Africa, 1920-1060" (D.Min. dissertation, Andrews University, 1996). 
Chimpempe Mission Station the Seventh-day Adventist message spread to other parts of the Luapula and the Northern Provinces.

\section{Zambia Union}

In 1921, "the Northern Rhodesia Field was set up with J. V. Wilson, the first president, and with headquarters at Lusaka. During two periods two sections of Northern Rhodesia [Zambia] functioned as separate fields, the area surrounding Chimpempe Mission (1926-1942) and Barotseland (1946-1948). In 1929 the European and coloured constituency of Northern Rhodesia became part of the Rhodesia Bechuanaland Conference. In 1945 the headquarters of Northern Rhodesia Field were moved to Chisekesi, a small settlement on the railroad, six miles (9.6 kilometers) from Rusangu Mission." ${ }^{40}$

Until the Zambia Union was formally organized in 1972, its territory was divided between Zambezi Union (Zimbabwe) and the Nyasaland Union (Malawi). When Zambia Union was organized Pastor A Bristow was its first president and W. M. Webster was the first secretary treasurer.

At the time of organization, "147 churches and 24,101 members were divided between the North Zambia Field, South Zambia Field, and West Zambia Field." ${ }^{\text {.41 }}$

\footnotetext{
${ }^{40}$ Seventh-day Adventist Church Encyclopedia, 1976 ed., s.v. "Musofu."

${ }^{41}$ Seventh-day Adventist Church Encyclopedia, 1976 ed., s.v. "Chimpempe Village."
} 
TABLE 1

NORTH ZAMBIA FIELD STATISTICAL REPORT FOURTH QUARTER 2006

\begin{tabular}{|l|c|l|l|c|}
\hline & Membership & Churches & Companies & $\begin{array}{l}\text { Branch Sabbath } \\
\text { Schools }\end{array}$ \\
\hline Bangweulu & 6,454 & 15 & 44 & 40 \\
\hline Chiunsali & 999 & 5 & 19 & 9 \\
\hline Chembe & 3,966 & 13 & 31 & 15 \\
\hline Chienge & 3,411 & 11 & 23 & 6 \\
\hline Ngumbo & 880 & 2 & 13 & 8 \\
\hline Isoka & 1,392 & 7 & 21 & 6 \\
\hline Kalungushi & 1,687 & 8 & 17 & 2 \\
\hline Kaputa & 2,489 & 13 & 43 & 8 \\
\hline Kasama & 7,532 & 34 & 80 & 33 \\
\hline Kawambwa & 2,938 & 12 & 17 & 3 \\
\hline Kazembe & 3,739 & 7 & 34 & 11 \\
\hline Luwingu & 3,173 & 10 & 63 & 62 \\
\hline Lwena & 2,925 & 13 & 24 & 6 \\
\hline Mansa North & 3,035 & 9 & 33 & 2 \\
\hline Mansa South & 6,895 & 20 & 30 & 70 \\
\hline Mbala & 3,276 & 18 & 45 & 5 \\
\hline Mpika & 3,166 & 12 & 62 & 7 \\
\hline Mpulungu & 5,449 & 25 & 40 & 4 \\
\hline Mporokoso & 2,770 & 15 & 50 & 7 \\
\hline Mwense & 6,796 & 23 & 45 & 22 \\
\hline Mweru & 5,253 & 21 & 38 & 6 \\
\hline Nakonde & 1,890 & 11 & 26 & 4 \\
\hline Nchelenge & 5,275 & 11 & 34 & 5 \\
\hline Senga Hill & 2,205 & 16 & 40 & 10 \\
\hline Totals & 90,245 & 331 & 872 & 351 \\
\hline
\end{tabular}




\section{North Zambia Field 1972--Present}

The decision to organize North Zambia Field was taken at a Zambezi Union meeting held at Blantyre in Malawi in June 1972. The North Zambia Field was organized on June $11,1972 .^{42}$ It was composed of the Copperbelt, Luapula, and Northern Provinces. This vast area had 48 churches and a membership of 9,584 members. Pastor A .M. C. Mpamba was elected as its first president, while financial matters were still processed at Monze in South Zambia Field which was better established at that time. ${ }^{43}$ The Copperbelt Province was organized into a separate field in 1989, leaving Luapula and Northern Provinces in the North Zambia Field, as the two regions that composed the current North Zambia Field through $2006{ }^{44}$

As of December 31, 2006, the North Zambia Field had 90,245 members, 24 districts, 331 churches, 872 companies, and 351 branch Sabbath Schools (see table 1). ${ }^{45}$ The office of the headquarters of the North Zambia Field is located at Mansa, on Independence Road, P.O. Box 710286, Mansa, in Luapula Province of Zambia, and the telephone number is $260-2-821363$.

${ }^{42}$ Although North Zambia Field was organized in 1972, its territory will be referred to as (NZF) prior to 1972.

${ }^{43}$ Ibid.

${ }^{44}$ Author was a pastor in the Seventh-day Adventist Church in the newly organized Copperbelt Zambia Field studying at Solusi University in Zimbabwe in 1989. 2006.

${ }^{45}$ Moses Mwenya, Secretary of the North Zambia Field, by email, February 20, 
In 2007 the territory of the North Zambia Field was adjusted so that Northern Province was organized as the North Zambia Field and Luapula Province was named the Luapula Zambia Field. This dissertation deals with the field as it was at the end of 2006.

\section{Evangelistic Methods for Church Growth}

Starting with the missionary-pioneers through the era of national leadership, the Zambia Union has used eight main models for evangelism: (1) schools, (2) clinics, (3) teachers and lay evangelists, (4) camp meetings, (5) Dorcas societies, (6) Voice of Prophecy Bible school, (7) public evangelism, and (8) literature evangelists. In addition, music, Adventist men's organization, a gift Bible plan, radio broadcasts, and television were used to deepen the new convert's faith in Christ.

\section{Schools}

In looking at what the missionaries brought to Zambia, it can be seen that "the missions and missionaries not only brought Christianity, they also brought education." ${ }^{.46}$ The early missionaries opened up new schools in Luapula Province, at Chimpempe, ${ }^{47}$ Kaseke, Mukonkoto, Chisheta, Lukwesa, Ponde, Mpanta, and Lifuka villages. In the Northern Province schools were opened at Mbala and Isoko. In the Copperbelt Province the early missionaries opened schools at Mutaba and Musofu villages. At these schools children were taught to read and write. They were also taught religious education, how to grow crops, and the use of manure, as opposed to the Chitemene (slash and burn). Many

\footnotetext{
${ }^{46}$ Bliss and Rigg, xiv.

${ }^{47}$ Thomson, 89.
} 
people in the North Zambia Field who attended these schools did not abandon what they were taught. Today some of these people are ministers in the government. For example, Dr. Katele Kalumba (Minister of Health, 1995-2000) had his primary education at Ponde Primary School. ${ }^{48}$

The use of schools for soul-winning was very successful in the villages along the Luapula River and Lake Mweru. It is not possible to tell the number of converts that were brought into the church through schools, but many former church workers testified of how useful this method was in evangelism. For example, the late Pastor Island Sinyangwe of Mbala Mission District (1955-2002) always talked about the Adventist education system and the people that had become Adventists because of the school influence. ${ }^{49}$ The goal had been for graduates to open their own schools, but this did not prove realistic. "All the students who attended mission schools were to later become evangelists who would establish schools in their home areas. Even though schools were established, they attracted only a few and could admit only limited numbers. A different strategy was needed to reach the masses that would not sit in the class. It was clear that education alone would not spread Christianity to every village.", 50

${ }^{48}$ Laban Chomba, Chilindi Village, near Ponde Primary School, was at the same school with Doctor Katele Kalumba between 1960-1965. Interviewed by the researcher by telephone on December 6, 2006.

${ }^{49}$ Pastor Island Sinyangwe, "Lecture on Adventist Schools" presented at Samfya District Seventh-day Adventist Church camp meeting, August 6-10, 1974, which the researcher attended.

${ }^{50}$ Matandiko, 63. 


\section{Health Centers}

In 1929, missionary H. J. Hurlow opened the first dispensary (health center) at Chimpempe. ${ }^{51}$ Later other health centers were opened at Kawambwa in Chief Munkanta's area, Loshi, Kambwali, and Lifuka villages. Medical missionary work spread to the Northern Province, where health centers opened at Senga and Isoko villages. At these clinics the patients were taught to take care of their health and the eight natural remedies: air, sunshine, rest, food, belief in a divine power, water, cleanliness, and exercise. Many of the people who were treated at these clinics were converted to Adventism. They often abandoned the use of traditional medicines administered by local village medicine men. "[I]t was becoming more evident that apart from schools, in certain places medical work would even do much better. F. B. Burton said, 'The medical work attracts the natives in a strong way, and is acceptable to the government. We must surely keep this branch of work in the forefront. At Chimpempe people came from far to receive medical attention. This contributed to the fast growth of work.", 52

Furthermore, "Although clinics were unsophisticated, the services they offered at that time were the best around compared to what traditional healers were offering. These simple clinics established where there were none, helped people come into contact with the gospel truth through mission doctors whose training at the time was simple, more practical and on site." 53

\footnotetext{
${ }^{51}$ Thomson, 89.

${ }^{52}$ Matandiko, 109-110.

${ }^{53}$ Ibid., 178.
} 
Teachers and Lay Evangelists

When the Zambia Union was organized in 1972 the leadership initiated a strategy to intensify evangelism. The church launched the evangelistic campaign at Rusangu Mission Station at Monze. It was held "in August 1972 where teachers from Seventh-day Adventist schools were called for a few days to study soul winning, the mission of the church, and the strategies to employ" ${ }^{\prime 54}$ in evangelism. It was resolved at this meeting that more lay workers and evangelists were needed for the program to succeed because trained pastoral teams were few.

Lay preachers in churches were asked to participate in soul winning. They happily took up the challenge to witness for Christ in the villages and towns throughout the North Zambia Field. Matandiko reports that a "lack of trained pastors and the fact that training of pastors would not match the membership explosion led to the fast training of laity. So, Rusangu Ministerial School was opened in 1975 with pastor Nelson Palmer and Pastor Job Koko as first teachers to train church elders to care for the local churches and train the pastors." "55 In 2004 Rusangu Ministerial School became Zambia Adventist University.

The North Zambia Field decided to send lay persons for training at Rusangu ministerial school. Some lay people decided to sponsor themselves at Rusangu ministerial school in order to serve their churches. For example, Miss Mary, Mr. Kabamba, and Mr.

${ }^{54}$ Ibid., 96.

${ }^{55}$ Matandiko, 213. 
Munshya (1977-1978) were lay evangelists who paid for their training expenses. ${ }^{56}$ Others were sponsored by their local churches. For example, Mr. Sikombe of Nakonde Mission District was sponsored by Libala Church in Lusaka (1978). ${ }^{57}$ Some of these trained lay evangelists were taken by the field to care for churches and later became full-time paid ministers. For example, Mr. Mwenshi of Samfya Mission District (1992-2002), Mr. Tambe a retiree of Mansa Mission District, (1978-1998), and Mr. Kalembe of Mansa (1995). ${ }^{58}$ Many souls were brought into the church through the efforts of these faithful evangelists. The evangelistic efforts conducted by these dedicated people bore fruit and still bears fruit today. The result is that there was an explosion of membership in the North Zambia Field. The number of converts of lay evangelists can be roughly estimated at about twenty percent of the total converts per year..$^{59}$

\section{Camp Meetings}

Camp meetings have been effective in soul winning from the pioneering days to the present. The early missionaries found out that schools were not the only avenues for soul winning, and decided to hold camp meetings at mission stations. The first camp meeting was held at Rusangu in the South Zambia Field in 1920, and the second one in

${ }^{56}$ Wellington Chapi, Associate Director at Rusangu Ministerial School, January 1, 1981. At this time Mary, Kabamba, and Mushya of Mkushi were students.

${ }^{57}$ Ibid. Mr. Sikombe was my classmate at Rusangu Ministerial School in 1978.

${ }^{58}$ The author was serving North Zambia Field as President where he met these three pastors between 2000 and 2002.

${ }^{59}$ Author's personal estimate. 
1922. The "Rusangu camp meeting was well attended, 200 people were present . . 26 people were baptized." ${ }^{.60}$

The first camp meeting in what is now the North Zambia Field was held at Musofu Mission Station. The "speakers were C. E. Wheeler, Director of Musofu Mission, and J. V. Wilson, the Superintendent of Northern Rhodesia Mission also joined the party at the camp site. About 300 people were baptized." ${ }^{61}$ From that time camp meetings were held at Chimpempe, Lifuka, Mbala, Samfya, Kawambwa, Kasama, Mansa, and in small towns and villages. In 2006 a total of " 24 camp meetings were conducted in 24 districts. About 10,000 converts and backsliders were won. Bringing the total Sabbath attendance to 89,000 people. ${ }^{962}$

\section{Dorcas Society}

When Pastor Daniel Lufungulo was Zambia Union Mission Director for Lay Activities between 1979 and 1985, he promoted District Dorcas Federations and intensified the Dorcas society's soul winning activities in the six fields of Zambia Union. ${ }^{63}$ One of the members of the Dorcas Society, Felistus Kawila Chapi of Chienge Boma in Luapula Province in the North Zambia Field, talked about what they were doing in their society. She said that in the Dorcas Society they helped the bereaved and the old. They

${ }^{60}$ Matandiko, 98.

${ }^{61}$ Ibid.

${ }^{62}$ Moses Mwenya, Secretary North Zambia Field by email, March 14, 2006.

${ }^{63}$ Pastor Lufungulo was Lay Activities Director at Zambia Union (1981-1985) in Lusaka. 
gave them food, clothes, and provided shelter. They cleaned homes for the elderly, visited the discouraged, and drew water from the village water wells. Finally, she said that they also attended funerals of the bereaved and took care of the children of the deceased persons in their communities. ${ }^{64}$ During the regular programs the women conducted evangelistic efforts. They had their own women speakers who spoke at these meetings from Sunday to Friday. On the Sabbath day, they invited male speakers from the church to come and make appeals for decisions (at that time the NZF administration felt that only men could make appeals on Sabbath. This was no longer the case after the 1990s).

Usually, there were large numbers of people who made decisions for Christ and the Dorcas Society members made arrangements to visit them until they were baptized and became full members of the Seventh-day Adventist Church.

[The] Dorcas Society training was not to be limited to physical and emotional needs only. Evangelistic training was introduced. Here women were taught how to conduct Bible studies, how to preach, and how to conduct evangelistic crusades. The excitement among women was incredible. They took up training seriously. The many who were trained began planting churches in their area of residence, led their neighbors to the Adventist message and had an impact in their communities. ${ }^{65}$

The total number of people who become members of the church through the Dorcas Society efforts in the North Zambia Field between 1980 and 2006 can be roughly estimated to be about 15 percent of the yearly number of new converts. ${ }^{66}$

${ }^{64}$ Felistus Kawila Chapi, Dorcas Society member in (NZF) interview by author, August 26, 2006.

\footnotetext{
${ }^{65}$ Matandiko, 170.

${ }^{66}$ Author's personal estimate.
} 


\section{Pastoral Public Evangelism}

Another method that was implemented in the North Zambia Field was public evangelism. This was introduced by the Zambia Union Conference and passed on to the Fields in Zambia. North Zambia Field adopted the action plans which involved both pastors and laymen in evangelism. The policies read in part:

1. That the Union, Field, committees lay concrete and detailed plans for all their workers to participate in active evangelistic campaigns.

2. Not only workers (ministers), but also the laymen, young and old, to be aroused to assist in evangelistic campaigns.

3. That every effort be made to train church members and lead them in persuasive and aggressive (VOP) enrollment campaign. ${ }^{67}$

This policy was totally implemented and was used to spread the gospel to all parts of the North Zambia Field. Many people came into contact with the Adventist message between 1972 and 2006. During this period "many churches were opened to accommodate large numbers of people who accepted Christ as their personal Savior and were baptized into the Seventh-day Adventist Church in North Zambia Field."

\section{Voice of Prophecy Bible School}

The Voice of Prophecy Bible School at Cape Town served Northern Rhodesia from 1922 until 1972. After 1972 when Zambia Union was organized, it was decided to open a

\footnotetext{
${ }^{67}$ Zambia Field Minutes of January 5-10, 1980, Action Number 324.

${ }^{68}$ Pastor Kawila of the North Zambia Field, interview by telephone, February 10 , 2006.
} 
Voice of Prophecy Bible School at Chisekesi in Monze to serve all the students in Zambia Union. Later the Zambia Union administration decided to decentralize the operations of the Voice of Prophecy Bible School so that the school sent lessons to the local fields and the pastors and laymen were involved in distribution of the lessons in their territory. In 1979, the Zambia Union Mission passed a recommendation to all fields to engage pastors and lay people to be actively involved in the promotion of "VOP [Voice of Prophecy] enrollment campaigns. ${ }^{969}$ Many people accepted Christ as their Savior in the North Zambia Field as a result of Voice of prophecy campaigns. Today, the Voice of Prophecy Bible School lessons are still sent to students in North Zambia Field and distributed by both the pastors and the laity. An estimated ten percent of the new converts were won through Voice of Prophecy activities. ${ }^{70}$

\section{Literature Evangelists}

In 1975, Dale Thomas ${ }^{71}$ was the Publishing Director for Zambia Union Mission. In 1976, he introduced massive literature ministry recruitment campaigns that lasted until 1990. These campaigns involved mass selling of magazines and books by literature evangelists in Zambia. The campaigns attracted many young people to join the literature ministry. From North Zambia Field, in particular, many young people went to Rusangu Ministerial School in the Southern Province of Zambia to train for the literature ministry. As a result of "these

${ }^{69}$ Matandiko, 179.

${ }^{70}$ Author's personal estimate.

${ }^{71}$ The author was serving as a pastor in the North Zambia Field when Dale Thomas was in Zambia. 
massive promotions large numbers of books written by Ellen G. White were sold in towns and villages in the North Zambia Field by "these eager and enthusiastic literature evangelists."72

The "importance of the work was promoted as second to none. It was regarded as the high calling." 973 The publishing work "grew very rapidly, some people left their regular jobs to join the publishing force full time. Some young people even left school to join the ministry. $" 74$

A different gospel among mostly the enthusiastic literature evangelists developed. It emphasized that, since Jesus was coming soon, there was no need to continue with school. Former high school students who joined the work at that time felt they could not continue wasting time going to school while souls were perishing. Yet, many of the people who bought these books read them and were converted to Adventism. Publishing work continues to grow and remains an effective method in soul winning in the North Zambia Field. About 9 percent of the converts joined the church as a result of the publishing ministry. ${ }^{75}$

\footnotetext{
${ }^{72}$ Matandiko, 179.

${ }^{73}$ Ibid., 208.

${ }^{74}$ Ibid.

${ }^{75}$ Author's personal estimate.
} 


\section{The Problem of Membership Loss}

The successes of soul wining activities of the North Zambia Field were accompanied by losses of newly baptized members through apostasy and going missing. As the evangelistic explosion which began in the 1960s intensified, the membership grew from 9,584 to 90,245 between 1973 and $2006 .{ }^{76}$

\section{The Scale of Membership Loss}

In the period 1996-2006, 72,652 new members came into the North Zambia Field through baptism or profession of faith. Of this number, 17,304 went out of membership in the field for reasons other than death or transfer to other SDA churches. This means that, on average, those going out of membership equaled 23.82 percent of those who came into membership each year. In all, the field lost an average of 2.70 percent of its total membership every year.

Table 2 compares the North Zambia Field with some other entities by presenting statistics for (1) members In through baptism and profession of faith, (2) members OUT through being dropped or going missing, (3) year-end net membership, (4) percentage of members going Out to those coming In, (5) percentage of total membership that went Out. The purpose of comparison is to gain perspective on the scale of membership loss in the North Zambia Field.

${ }^{76}$ Seventh-day Adventist Church Website of the North Zambia Field, www.adventiststatistics.org ( March 5, 2006). 
Looking at the ratio of members who went out to members who came in during a given year, the following comparisons can be made: The field's 23.82 percent was a little better than the Zambia Union (24.3 percent), a little worse than the Southern-Africa Indian Ocean Division (20.60 percent), much better than the North American Division (42.69 percent), and a little better than the General Conference world average of 27.82 percent. As for the ratio of membership loss to total membership, the North Zambia Field's 2.70 percent was better than the Zambia Union (2.90 percent), worse than the Southern-Africa Indian Ocean Division (1.93 percent), worse than the North American Division (1.71 percent), and worse than the General Conference global average of 2.01 percent. These comparisons do not take into account differences in church discipline, administrative attitudes, and technical aspects of membership keeping that may be present in different church entities. Whatever the North Zambia Field membership statistics may suggest when compared with other church entities, the bare facts remain that between 1996 and 2006, 17,304 church members were dropped or declared missing for various reasons. This large number of former members represents a significant failure in the work that God has given His church. Sadly, some members will always experience the spiritual or moral collapse that takes them out of membership. However, the Church has an obligation to do all in its power to implement good retention strategies. This dissertation proposes a retention modal based on small groups. 
TABLE 2

\section{NORTH ZAMBIA FIELD MEMBERSHIP ADDITION AND ATTRITION 1996-2006}

\begin{tabular}{|c|c|c|c|c|c|}
\hline $\begin{array}{l}\text { NORTH } \\
\text { ZAMBIA } \\
\text { FIELD }\end{array}$ & $\begin{array}{c}\text { IN } \\
\text { Baptism \& } \\
\text { Profession }\end{array}$ & $\begin{array}{c}\text { OUT } \\
\text { Dropped \& } \\
\text { Missing }\end{array}$ & $\begin{array}{c}\text { Total } \\
\text { Membership }\end{array}$ & $\begin{array}{l}\text { Percentage } \\
\text { OUT to } \\
\text { IN }\end{array}$ & $\begin{array}{c}\text { Percentage } \\
\text { Membership } \\
\text { OUT }\end{array}$ \\
\hline 1996 & 3,886 & 3,979 & 45,046 & $102.39 \%$ & $8.83 \%$ \\
\hline 1997 & 6,881 & 1,698 & 47,569 & $24.68 \%$ & $3.57 \%$ \\
\hline 1998 & 7,306 & 1,501 & 53,004 & $20.54 \%$ & $2.83 \%$ \\
\hline 1999 & 5,650 & 1,031 & 56,551 & $18.25 \%$ & $1.82 \%$ \\
\hline 2000 & 7,483 & 803 & 58,171 & $10.73 \%$ & $1.38 \%$ \\
\hline 2001 & 7,781 & 1,049 & 63,293 & $13.48 \%$ & $1.66 \%$ \\
\hline 2002 & 7,628 & 3,899 & 69,838 & $51.11 \%$ & $5.58 \%$ \\
\hline 2003 & 7,194 & 545 & 76,515 & $7.58 \%$ & $0.71 \%$ \\
\hline 2004 & 7,394 & 1,387 & 81,909 & $18.76 \%$ & $1.69 \%$ \\
\hline 2005 & 4,969 & 627 & 85,448 & $12.61 \%$ & $0.73 \%$ \\
\hline 2006 & 6,480 & 785 & 90,245 & $12.11 \%$ & $0.87 \%$ \\
\hline TOTAL & 72,652 & 17,304 & & $23.82 \%$ & $2.70 \%$ \\
\hline Per Year & 6,605 & 1,573 & & & \\
\hline \multicolumn{6}{|c|}{ Source: General Conference Annual Statistical Reports } \\
\hline \multirow[t]{2}{*}{ ZAMBIA } & UNION & & & & \\
\hline & $\begin{array}{c}\text { IN } \\
\text { Baptism \& } \\
\text { Profession }\end{array}$ & $\begin{array}{c}\text { OUT } \\
\text { Dropped \& } \\
\text { Missing }\end{array}$ & Membership & $\begin{array}{c}\text { Percentage } \\
\text { Members OUT } \\
\text { to IN }\end{array}$ & $\begin{array}{c}\text { Percentage } \\
\text { Members } \\
\text { OUT }\end{array}$ \\
\hline 1996 & 41,186 & 16,926 & 273,298 & $41.10 \%$ & $6.19 \%$ \\
\hline 1997 & 51,573 & 17,055 & 283,738 & $33.07 \%$ & $6.01 \%$ \\
\hline 1998 & 47,190 & 16,881 & 309,200 & $35.77 \%$ & $5.46 \%$ \\
\hline 1999 & 29,103 & 2,963 & 332,915 & $10.33 \%$ & $0.89 \%$ \\
\hline 2000 & 46,515 & 7,833 & 359,244 & $16.84 \%$ & $2.18 \%$ \\
\hline 2001 & 36,549 & 10,789 & 381,585 & $29.52 \%$ & $2.83 \%$ \\
\hline 2002 & 35.060 & 9,247 & 408,303 & $26.37 \%$ & $2.26 \%$ \\
\hline $2003^{*}$ & 40,361 & 8,852 & 437,527 & $21.93 \%$ & $2.02 \%$ \\
\hline 2004 & 48,321 & 7,539 & 471,095 & $15.60 \%$ & $1.60 \%$ \\
\hline
\end{tabular}


Table 2--Continued

\begin{tabular}{|c|c|c|c|c|c|}
\hline 2005 & 38,281 & 8,221 & 497,030 & $21.48 \%$ & $1.65 \%$ \\
\hline \multirow[t]{2}{*}{2006} & 41,715 & 4,477 & 530,165 & $10.73 \%$ & $0.84 \%$ \\
\hline & 455,854 & 110,783 & & $24.30 \%$ & $2.90 \%$ \\
\hline \multirow[t]{2}{*}{ SOUTHERN } & AFRICA & INDLAN & OCEAN & DIVISION & \\
\hline & $\begin{array}{c}\text { IN } \\
\text { Baptism \& } \\
\text { Profession }\end{array}$ & $\begin{array}{c}\text { OUT } \\
\text { Dropped \& } \\
\text { Missing }\end{array}$ & Membership & $\begin{array}{c}\text { Percentage } \\
\text { Members OUT } \\
\text { to IN }\end{array}$ & $\begin{array}{l}\text { Percentage } \\
\text { Members } \\
\text { OUT }\end{array}$ \\
\hline 1996 & 158,653 & 40,322 & $1,579,726$ & $25.42 \%$ & $2.55 \%$ \\
\hline 1997 & 159,803 & 38,259 & $1,655,091$ & $23.94 \%$ & $2.31 \%$ \\
\hline 1998 & 182,145 & 67,192 & $1,710,862$ & $36.89 \%$ & $3.93 \%$ \\
\hline 1999 & 256,766 & 32,953 & $1,895,934$ & $12.83 \%$ & $1.74 \%$ \\
\hline 2000 & 222,833 & 34,644 & $2,060,376$ & $15.55 \%$ & $1.68 \%$ \\
\hline 2001 & 184,751 & 41,910 & $2,194,121$ & $22.68 \%$ & $1.91 \%$ \\
\hline 2002 & 177,986 & 46,042 & $2,208,263$ & $25.87 \%$ & $2.08 \%$ \\
\hline $2003^{*}$ & 121,476 & 24,980 & $1,713,768$ & $20.567 \%$ & $1.46 \%$ \\
\hline 2004 & 185,683 & 24,818 & $1,863,895$ & $13.37 \%$ & $1.33 \%$ \\
\hline 2005 & 141,835 & 24,623 & $1,961,735$ & $17.36 \%$ & $1.26 \%$ \\
\hline \multirow[t]{2}{*}{2006} & 134,729 & 21,071 & $2,064,919$ & $15.64 \%$ & $1.02 \%$ \\
\hline & $1,926,660$ & 396,814 & & $20.60 \%$ & $1.93 \%$ \\
\hline \multirow[t]{2}{*}{ NORTH } & AMERICAN & DIVISION & & & \\
\hline & $\begin{array}{c}\text { IN } \\
\text { Baptism \& } \\
\text { Profession }\end{array}$ & $\begin{array}{c}\text { OUT } \\
\text { Dropped \& } \\
\text { Missing }\end{array}$ & Membership & $\begin{array}{c}\text { Percentage } \\
\text { Members OUT } \\
\text { to IN }\end{array}$ & $\begin{array}{c}\text { Percentage } \\
\text { Members } \\
\text { OUT }\end{array}$ \\
\hline 1996 & 39,004 & 14.041 & 858,364 & $36.00 \%$ & $1.64 \%$ \\
\hline 1997 & 35,493 & 34,005 & 875,811 & $95.81 \%$ & $3.88 \%$ \\
\hline 1998 & 35,984 & 15,057 & 891,175 & $41.84 \%$ & $1.69 \%$ \\
\hline 1999 & 40,766 & 13,250 & 914,106 & $32.50 \%$ & $1.45 \%$ \\
\hline 2000 & 36,594 & 12,953 & 933,935 & $35.40 \$$ & $1.39 \%$ \\
\hline 2001 & 36,966 & 11,990 & 955,076 & $32.44 \%$ & $1.26 \%$ \\
\hline 2002 & 36,896 & 12,965 & 974,271 & $35.14 \%$ & $1.33 \%$ \\
\hline 2003 & 37,445 & 17,038 & 992,046 & $45.50 \%$ & $1.72 \%$ \\
\hline 2004 & 36,887 & 17,257 & $1,006,317$ & $46.78 \%$ & $1.71 \%$ \\
\hline
\end{tabular}


Table 2--Continued

\begin{tabular}{|c|c|c|c|c|c|}
\hline 2005 & 36,700 & 14,575 & $1,024,035$ & $39.71 \%$ & $1.42 \%$ \\
\hline \multirow[t]{2}{*}{2006} & 38,718 & 13,326 & $1,041,685$ & $34.42 \%$ & $1.28 \%$ \\
\hline & 411,453 & 176,457 & & $42.89 \%$ & $1.71 \%$ \\
\hline \multirow[t]{2}{*}{ GENERAL } & CONFERENCE & & & & \\
\hline & $\begin{array}{c}\text { IN } \\
\text { Baptisms \& } \\
\text { Profession } \\
\end{array}$ & $\begin{array}{c}\text { OUT } \\
\text { Dropped \& } \\
\text { Missing }\end{array}$ & Membership & $\begin{array}{c}\text { Percentage } \\
\text { Members OUT } \\
\text { to IN }\end{array}$ & $\begin{array}{l}\text { Percentage } \\
\text { Members } \\
\text { OUT }\end{array}$ \\
\hline 1996 & 719,679 & 187,833 & $9,296,127$ & $26.10 \%$ & $2.02 \%$ \\
\hline 1997 & 744,798 & 191,661 & $9,702,834$ & $25.73 \%$ & $1.98 \%$ \\
\hline 1998 & 818,754 & 241,870 & $10,939,182$ & $29.54 \%$ & $2.38 \%$ \\
\hline 1999 & $1,090,848$ & 82,003 & $10,939,182$ & $7.04 \%$ & $1.66 \%$ \\
\hline 2000 & $1,043,843$ & 212,866 & $11,687,239$ & $20.82 \%$ & $1.82 \%$ \\
\hline 2001 & 961,542 & 244,944 & $12,320,844$ & $3.24 \%$ & $0.25 \%$ \\
\hline 2002 & 980.920 & 227,034 & $12,894,015$ & $23.82 \%$ & $1.76 \%$ \\
\hline 2003 & 991,717 & 349,724 & $13,406,554$ & $35.26 \%$ & $2.61 \%$ \\
\hline 2004 & $1,071,135$ & 363,040 & $13,936,932$ & $33.89 \%$ & $2.60 \%$ \\
\hline 2005 & $1,057,852$ & 476,351 & $14,399,072$ & $45.03 \%$ & $3.31 \%$ \\
\hline \multirow[t]{2}{*}{2006} & $1,107,425$ & 268,154 & $15,115,806$ & $24.21 \%$ & $1.77 \%$ \\
\hline & $10,588,513$ & $2,945,480$ & & $27.82 \%$ & $2.01 \%$ \\
\hline \multicolumn{6}{|l|}{ SUMMARY } \\
\hline & $\begin{array}{c}\text { IN } \\
\text { Baptism \& Profession }\end{array}$ & $\begin{array}{c}\text { OUT } \\
\text { Dropped \& } \\
\text { Missing }\end{array}$ & $\begin{array}{c}\text { Percentage } \\
\text { Members OUT } \\
\text { to IN }\end{array}$ & $\begin{array}{c}\text { Percentage } \\
\text { Membesr } \\
\text { OUT }\end{array}$ & \\
\hline North Zambia & 72,652 & 17,304 & $23.82 \%$ & $2.70 \%$ & \\
\hline Zambia Union & 455,854 & 110,783 & $24.30 \%$ & $2.90 \%$ & \\
\hline Southern Africa & $1,926,660$ & 396,814 & $20.60 \%$ & $1.93 \%$ & \\
\hline North America & 411,453 & 176,457 & $42.89 \%$ & $1.71 \%$ & \\
\hline General Conference & $10,588,513$ & $2,945,480$ & $27.82 \%$ & $2.01 \%$ & \\
\hline
\end{tabular}




\section{Reasons Why People Leave the Church}

A survey was conducted between September 2005 and September 2006 to identify reasons why newly baptized members leave the church. This survey focused on factors within the church and factors in the life of individual converts which cause people to leave the church.

Eleven Factors Within the Church for Membership Loss

The North Zambia Field has 24 districts which are manned by 16 pastors, with a total church membership of 90,245 as of December 31,2006 . The sixteen pastors were asked to Indicate the importance of eleven factors by stating that they were (1) "not a reason,"(2) "somewhat a reason," and (3) "a strong reason." It should be noted that the survey measured pastoral perceptions. Table 3 summarizes the findings.

\section{The Factor of Jealousy}

In factor 1, pastors responded to the statement "Established older church members and church leaders are jealous of new converts who are potential leaders, and are willing to participate in any church programs. To guard their own positions in the church the established members hold new members back."

Research revealed that this is "not a reason" in twelve districts: Mporokoso, Mansa North, Lwena, Kawambwa, Kalungushi, Bangweulu, Chembe, Chinsali, Kasama, Luwingu, Mbala, and Mansa South. Jealousy is "somewhat" a reason in eight districts: Mpulungu, Mwense, Mweru, Ngumbo, Nakonde, Mpika, Isoka, and Nchelenge. It is "a strong reason" 
in four districts: Kazembe, Kaputa, Chienge, and Mweru. The findings suggest that this factor is moderately influential.

\section{Lack of Training and Equipping Opportunities}

In factor 2, pastors responded to the statement, "In church elections only highly educated converts are picked for training and equipping for service. The middle class and lower class members, who make up the majority of converts, are left out of the training programs."

Research shows that this factor "is not a reason" in the following eleven districts: Bangweulu, Chembe, Mansa South, Mwense, Nchelenge, Kazembe, Kaputa, Mweru, Nakonde, Ngumbo, and Kasama. It "is somewhat" a factor in ten districts: Mporokoso, Mansa North, Mpulungu, Mpika, Chinsali Mpulungu, Senga Hill, Luwingu, Isoka, and Chienge. It is "a strong reason" in three districts: Kalungushi, Kawambwa, and Lwena. The findings suggest that this factor is influential for membership loss.

\section{Lack of Felt Needs Seminars for New Believers}

In factor 3, pastors responded to the statement, "The needs of the new converts are not adequately addressed in meetings and seminars designed especially for them. (For example, there are no separate programs for new converts with personal problems like smoking, drinking, etc.)"

It is discouraging to note that there was no district where it was said that it was "not a reason." The respondents were divided in two camps of importance, that is, "somewhat of a reason" and "a strong reason" for which members leave the church. It is "somewhat of 
a reason" in eleven districts: Kazembe, Chembe, Mansa South, Ngumbo, Isoka, Kaputa, Kawambwa, Lwena, Luwingu, Chinsali, and Bangweulu.

Furthermore, thirteen pastors said that it is "a strong reason" in Nchelenge, Mwense, Kasama, Mporokoso, Mansa North, Mpulungu, Chienge, Kalungushi, Mbala, Mpika, Mweru, Nakonde, and Senga Hill districts. These findings point out that this factor is a strong one.

\section{Sabbath Afternoon Activities Focused on Older Members}

In factor 4, pastors were asked to respond to the statement, "Bible studies conducted every Sabbath afternoon are focused on benefitting older members instead of the needs and spiritual growth of new members."

No pastors responded that it is "not a reason" for members dropping out of the church. Ten district pastors said that it is "somewhat of a reason" in Kasama, Mwense, Nchelenge, Bangweulu, Mansa South, Kazembe, Ngumbo, Chinsali, Isoka, and Chembe districts. Fourteen pastors indicated that it is "a strong reason" in Kawambwa, Kalungwishi, Lwena, Mansa North, Mweru, Mpulungu, Kaputa, Nchelenge, Chienge, Luwingu, Mbala, Mpika, Mporokoso, and Senga Hill districts. This is an important factor in membership loss.

\section{Lack of Bonding with New Believers}

In factor 5, pastors were asked to respond to the statement, "Older members and leaders of the church often fail to build long and lasting relationships with new members." 
Pastors said that it is "not a reason" in nine districts: Mansa North, Mansa South, Samfya, Isoka, Mpika, Chinsali, Luwingu, Mweru, and Nakonde.

It is "somewhat of a reason" in four districts: Kawambwa, Kalungushi, Ngumbo, and Lwena districts. It is "a strong reason" in eleven districts: Kaputa, Mporokoso, Mbala, Mpulungu, Chienge, Chembe, Kazembe, Bangweuliu, Nchelenge, Kasama, and Mwense. This is a moderately important factor in membership loss.

\section{Policing Rather than Teaching Church Standards}

In factor 6, pastors were asked to respond to the statement, "Instead of acting in a redemptive way to help new believers grow in their faith and practice, the older members, leaders, and deacons act like police officers who catch new converts in violation of the Ten Commandmnets and the church standards." It was "not a reason" in four districts: Chinsali, Isoka, Kasama, and Senga Hill. It was "somewhat of a reason" in eleven districts:

Kalungushi, Kawambwa, Mporokoso, Nakonde, Mpulungu, Chembe, Kazembe, Bangweulu, Luwingu, Lwena, and Mansa South. It was "a strong reason" in nine districts: Mweru, Kaputa, Mansa North, Chienge, Nchelenge, Mbala, Mpika, Ngumbo, and Mwense. This is an important factor.

\section{Lack of Mentors}

In factor 7, pastors were asked to respond to the statement, "New converts are not usually assigned to mature members who will mentor them." The survey showed that there were no districts where this factor was "not a reason." It was "somewhat a reason" in four districts: Mansa North, Mansa South, Kasama, and Kawambwa. It was "a strong reason" in 
twenty districts: Bangweulu, Chinsali, Chembe, Chienge, Ngumbo, Isoka, Kalungushi, Kaputa, Kazembe, Senga Hill, Nchelenge, Nakonde, Luwingu, Lwena, Mbala, Mpika, Mpulungu, Mweru, Mwense, and Nakonde. This is a very important factor.

\section{Ministry Opportunities Not Based on Spiritual Gifts}

In factor 8 , pastors were asked to respond to the statement, "New converts are usually not placed in appropriate ministries after their baptism based on their spiritual gifts." This survey showed that there were no districts where this is "not a reason." It was "somewhat of a reason" in ten districts: Kalungushi, Kawambwa, Lwena, Bangweulu, Chienge, Ngumbo, Isoka, Kaputa, Luwingu, and Nchelenge. It was "a strong reason" in fourteen districts: Kasama, Mporokoso, Mpulungu, Mansa South, Kazembe, Chembe, Mweru, Mansa North, Mbala, Mpika, Mweru, Nakonde, Senga Hill, and Mwense. The pastors saw this as a very important factor.

\section{Exclusive Family Leadership}

In factor 9, pastors were asked to respond to the statement, "Many churches are 'family churches,' meaning that one or two families control and lead out in all phases of church programs, making it hard for new members to participate." The survey showed that this factor is "not a reason" in ten districts: Chinsali, Chembe, Isoka, Mansa North, Kasama, Luwingu, Mansa South, Mbala, Mpika, and Nakonde. This factor is "somewhat of a reason" in these four districts, Bangweulu, Chienge, Mporokoso, and Mwense. It is "a strong reason" in ten districts: Kalungwishi, Kawambwa, Lwena, Nchelenge, Mpulungu, Kazembe, Mweru, Nakonde, Senga Hill, and Kaputa. This is an important factor. 


\section{Lack of Preparation for Discipling Before Baptism}

In factor 10 , pastors were asked to respond to the statement, "New converts do not receive adequate instructions before baptism." The survey showed that there were no districts where this factor was "not a reason." It was "somewhat of a reason" in eleven districts: Bangweulu, Chinsali, Chembe, Chienge, Ngumbo, Isoka, Kalungwishi, Kaputa, Kasama, Kawambwa, and Kazembe. It was "a strong reason" in thirteen districts: Luwungu, Lwena, Mansa North, Mansa South, Mbala, Mpika, Mpulungu, Mporokoso, Mwense, Nakonde, Nchelenge, Mweru and Senga Hill. This is a very important factor.

\section{Older Members Lacking Evangelistic Zeal}

In factor 11, pastors were asked to respond to the statement, "Established church members are not adequately involved in evangelism programs that bring new converts into the church." The pastors of ten districts indicated that this was "not a reason": Kaputa, Mansa North, Chienge, Lwena, Mwense, Kazembe, Mpika, Luwingu, Chinsali, and Isoka. It was "somewhat of a reason" in five districts, Mbala, Mansa South, Mweru, Senga Hill, and Nchelenge. However, it was "a strong reason" in nine districts: Kawambwa, Kalungwishi, Nakonde, Mpulungu, Mporokoso, Kawambwa, Kasama, Ngumbo, and Bangweulu. This factor is of a low influence in membership loss.

\section{Factors of Specific Districts}

A number of factors not included in the survey were added by pastors. Six pastors in eight districts mentioned seven factors as "strong reasons" for membership loss. These 
factors are "boring Sabbath afternoon programs" and "uncared for orphans" in Mwense; and "spiritualism" in Mweru; "youth marriages with unbelievers" in Mwense and Nchelenge; "cleansing of the surviving spouse" in Nchelenge; "offshoots" in Mwense and Mweru; "lack of spiritual books" (Bible, study guides, and Spirit of Prophecy books) in Kazembe, Kawambwa, Kalungwishi, Mpulungu, and Lwena.

\section{Summary}

Table 3 ranks eleven factors in their order of significance. Clearly, the factors that rank highest need to be given first priority in a strategy to increase new member retention. The dominance of a particular family in church leadership needs to be addressed (Factor 9). New members need to be given mentors (Factor 7). Serious addressing of felt needs of new members (Factor 3) needs to be offered. Eight factors raised by specific districts need to be included in the strategies. Factors having less urgent need also to be addressed in a complete package of new member retention strategies. 
TABLE 3

FACTORS OF POOR MEMBER RETENTION

\begin{tabular}{|l|c|c|c|c|c|c|}
\hline Factor & $\begin{array}{c}\text { "Not a } \\
\text { Reason" }\end{array}$ & $\begin{array}{c}\text { "Somewhat } \\
\text { of a Reason" }\end{array}$ & $\begin{array}{c}\text { Score } \\
\text { (1) }\end{array}$ & $\begin{array}{c}\text { "Strong } \\
\text { Reason" }\end{array}$ & $\begin{array}{c}\text { Score } \\
\text { (2) }\end{array}$ & Total \\
\hline & & & & & & \\
\hline $\begin{array}{l}\text { 9. Exclusive family } \\
\text { churches }\end{array}$ & 0 & 4 & 4 & 20 & 40 & 44 \\
\hline 7. Lack of mentoring & 0 & 4 & 4 & 20 & 40 & 44 \\
\hline 3. Lack of seminars & 0 & 4 & 4 & 20 & 40 & 44 \\
\hline 8. No spiritual gifts focus & 0 & 10 & 10 & 14 & 28 & 38 \\
\hline $\begin{array}{l}\text { 10. Poor pre-baptism } \\
\text { preparation }\end{array}$ & 0 & 11 & 11 & 13 & 26 & 37 \\
\hline 5. Lack of bonding & 1 & 12 & 12 & 11 & 22 & 34 \\
\hline 1. Jealousy & 8 & 3 & 3 & 13 & 26 & 29 \\
\hline 6. Policing attitude & 3 & 11 & 11 & 9 & 18 & 29 \\
\hline 4. No felt-needs seminars & 7 & 7 & 7 & 10 & 20 & 27 \\
\hline 2. Lack of training & 9 & 5 & 5 & 10 & 20 & 25 \\
\hline $\begin{array}{l}\text { 11. Older members lack } \\
\text { evangelistic zeal }\end{array}$ & 10 & 5 & 5 & 9 & 18 & 23 \\
\hline
\end{tabular}

\section{Personal Reasons for Dropping Out}

After asking the pastors to identify factors in the church that hinder membership retention, the survey turned to behaviors or attitudes that caused members to have their names removed from church records or to request that their names be dropped. Twenty-five behaviors or attitudes were taken from the latest edition of the Seventh-day Adventist Church Manual, $17^{\text {th }}$ ed., 2005, pp. 185-200.

The survey asked, "For what reasons do new members most commonly have their names removed from church records?" The following factors were identified by the pastors. 
Idolatry, Blasphemy and Profanity

Idolatry or worship of idols, "yes it is a factor" in thirteen districts. Blasphemy, taking the name of God in vain, "yes it is a factor" in two districts. Profanity, "yes it is a factor" in nine districts.

Gambling, Domestic Violence, Dishonoring Parents, Sabbath Breaking, Adultery, Fornication, Homosexual Practice, Incest, Sexual Abuse of Children and Vulnerable Adults

Gambling, "yes it is a factor" in two districts. Domestic Violence, "yes it is a factor" in two districts. Dishonoring of parents, "was not named as a factor" in any of the districts. Sabbath breaking, "yes it is a factor" in thirteen districts. Adultery (when at least one is married), "yes it is a factor" in sixteen districts. Fornication (between unmarried people), "yes it is a factor" in twenty-four districts. Homosexual practice, "yes it is a factor" in one district. Incest, "yes it is a factor" in four districts. Sexual abuse of children and vulnerable adults, "was not named as a factor" in any of the districts.

Remarriage on Unbiblical Grounds, Physical Violence or Murder, Fraud or Misrepresentation in Business, Falsehood, Coveting, Envy, Non-attendance of Church, Persistent Refusal to Recognize Properly Constituted Church Authority or Submit to the Order and Discipline of the Church.

Remarriage on unbiblical grounds, "yes it is a factor" in fourteen districts. Physical violence or murder "yes it is a factor" in three districts.

Fraud or misrepresentation in business, "yes it is a factor" in three districts. Falsehood, "yes it is a factor" in four districts. Coveting, envy, non attendance, and 
persistent refusal to recognize properly constituted church authority to submit to the order and discipline of the church, "was not named as a factor" in any of the districts.

Adhering to or Taking Part in a Decisive Disloyal Movement or Organization, Disorderly Conduct That Brings Reproach Upon the Church, Use or Manufacture or Sale of Narcotic Drugs, Use or Manufacture of Tobacco

Adhering to or taking part in a divisive or disloyal movement or organization, "yes it is a factor" in seven districts. Disorderly conduct that brings reproach upon the church, "yes it is a factor" in eight districts.

The use, manufacture, or sale of narcotic drugs, "yes it is a factor" in two districts. The use, manufacture, or sale of tobacco, "yes it is a factor" in nine districts.

Use, Manufacture, or Sale of Alcoholic Beverages, and Witchcraft or Participation in Non-Christian Traditional Practices

The use, manufacture, or sale of alcoholic beverages, "yes it is a factor" in fourteen districts. Witchcraft or participation in non-Christian traditional practices or beliefs, "yes it is a factor" in thirteen districts.

\section{Ranking the Personal Reasons for Members}

The survey responses about factors that lead to membership loss fell naturally into three clusters or groups. The most serious factors were (1) idolatry, (2) Sabbath breaking, (3) adultery, (4) fornication, and (5) the use, manufacture, and sale of tobacco. 
The moderately significant factors were (1) re-marriage on unbiblical grounds, (2) falsehood, (3) adhering to or taking part in a divisive or disloyal movement or organization, (4) disorderly conduct which brings reproach upon the church, or (5) physical violence. The least significant factors were (1) profanity, (2) gambling, (3) violence in the family, (4) the use, manufacture, or sale of alcoholic beverages, (5) the use, manufacture, or sale of narcotic drugs, (6) fraud or misrepresentation in business, and (7) homosexual practice.

\section{Summary}

An effective membership retention strategy must give priority to the most significant personal factors that lead to membership loss. According to this research, the most significant factor involves idolatry or issues related to African traditional religion. The second area involves Sabbath breaking in the Zambian context. The third area involves sexual immorality. These are followed by less significant factors that must be part of a good retention strategy.

\section{Activities to Enhance Retention, Assimilation, and Discipling of New Converts}

Newly baptized members in the North Zambia Field drop out or leave church for various reasons. Lack of proper retention, assimilation, and disciple-making opportunities for new members in the churches are major problems. Seventeen possible activities were named and pastors were asked to indicate whether they were "Not done," "Done for some 
new converts," or "Done almost always for new converts." The following are their responses (see table 4).

Activity 1. A Warm Welcome for New Believers

In activity 1 , pastors responded to the statement, "Churches welcome new members warmly into the church after they are baptized." No pastors reported that this activity is "not done." Ten pastors reported that it is "done for some new converts" in Mpulungu, Mwense, Mporokoso, Chinsali, Ngumbo, Isoka, Luwingu, Mbala, Mpika, and Nakonde districts. Fourteen pastors reported that it is "done always for new converts" in Kawambwa, Kalungwishi, Mansa North, Chembe, Kasama, Bangweulu, Mansa South, Lwena, Nchelenge, Chienge, Mweru, Kazembe, Kaputa, and Senga Hill districts. Clearly the pastors believe that their churches provide a warm welcome for new members.

\section{Activity 2. Fellowship Dinners}

In activity 2, the pastors responded to the statement, "Churches invite new members to a welcome table for a special meal typically on the day of baptism with all members, elders, and the pastor." The pastor reported that it is "not done" in these thirteen districts: Bangweulu, Mpulungu, Mwense, Mporokoso, Mansa North, Chembe, Kasama, Mansa South, Nchelenge, Mweru, Chienge, Kaputa, and Kazembe. They said that it is "done for some converts" in these eight districts: Lwena, Chinsali, Isoka, Kaputa, Luwingu, Mbala, Mpika, and Mpulungu. Pastors reported that it is "done almost always for new new converts" in Kawambwa, Kalungwishi, and Lwena districts. The data suggest that this activity needs more emphasis. 


\section{Activity 3. Baptismal Gifts}

In activity 3 , the pastors responded to the statement, "Churches give each baptized new member a free Bible, hymn book, and Sabbath School Study Guide." The pastors responded that this activity is "not done" in twenty-two districts; Bangweulu, Mpulungu, Mporokoso, Mansa North, Chembe, Kasama, Mweru, Chienge, Kaputa, Kazembe, Kawambwa, Kalungwishi, Chinsali, Ngumbo, Chienge, Isoka, Kasama, Mansa South, Mbala, Mpika, Nakonde, Senga Hill, and Lwena. They reported that this activity is "done for some new converts" in Nchelenge district and is "done almost always for new converts" in Mwense district. The idea of baptismal gifts seems foreign to the North Zambia Field church.

\section{Activity 4. Mentors}

In activity 4 , the pastors responded to the statement, "Churches assign an established member as a mentor to each of the newly baptized members to bring them into fellowship, and to ground them in the faith." The pastors reported that this activity is "not done " in five districts: Bangweulu, Chisali, Kazembe, Kasama and Kawambwa. This activity is "done for some new converts" in eleven districts: Mansa South, Mansa North, Kalungwishi, Mpika, Senga Hill, Ngumbo, Mweru, Nchelenge, Isoka, Mpulungu, and Nakonde. It is "done always for new converts" in nine districts: Luwingu, Chembe, Chienge, Mporokoso, Mbala, Mwense, Lwena, and Kaputa. The churches seems to be doing moderately well in involving mentor but more could be done. 


\section{Activity 5. New Believer Classes}

In activity 5 , the pastors responded to the statement, "Churches arrange special classes taught by elders for new converts" in their districts. The pastors reported that this activity is "not done" in six districts: Kawambwa, Kalungwishi, Lwena, Kalungwushi, Isoka, and Chembe. It is "done for some new converts" in eight districts: Mpulungu, Mporokoso, Ngumbo, Mansa South, Mweru, Chienge, Mbala, and Nakonde. They said that this activity is "done almost always for new converts" in ten districts: Bangweulu, Mansa North, Kasama, Kaputa, Kazembe, Nchelenge, Mwense, Mpulungu, Senga Hill, and Mpika. Pastors should encourage church elders to form special classes for new members in their churches.

\section{Activity 6. Meeting Felt Needs}

In activity 6 , the pastors responded to the statement, "Churches find out each new convert's needs and attend to each of the needs as best as they can." The pastors reported that this is "not done" in six districts: Mporokoso, Kasama, Chinsali, Mpika, Isoka, and Kazembe. They said it is "done for some new converts" in fifteen districts: Kawambwa, Kalungushi, Lwena, Mpulungu, Chembe, Mansa South, Mweru, Chienge, Bangweulu, Mansa North, Kaputa, Mbala, Mpulungu, Mwense, and Kazembe. It is "done almost always for new converts" in three districts, Luwingu, Ngumbo, and Senga Hill. This activity is done moderately but needs more emphasis. 


\section{Activity 7. Small Group Discussions with Elders}

In activity 7 , the pastors responded to the statement, "Churches arrange special question and answer sessions conducted by elders or the pastors for groups of new converts." The pastors reported that this is "not done" in fifteen districts; Mporokoso, Kasama, Kawambwa, Kalungwishi, Lwena, Mpulungu, Chembe, Mansa South, Mweru, Chienge, Mansa North, Luwingu, Mpulungu, Kazembe, and Kaputa. It is "done for some new converts" in four districts: Nchelenge, Mpika, Chinsali, and Isoka. They reported that it is "done almost always for new converts" in five districts: Kazembe, Bangweulu, Senga Hill, Ngumbo, and Mwense. This activity is rarely done and needs more emphasis.

\section{Activity 8. Individual Counseling}

In activity 8 , the pastors responded to the statement, "Churches provide individual counseling for new converts to address personal problems." The pastors reported that it is "not done" in six districts: Mansa South, Bangweulu, Chembe, Mpika, Nchelenge, and Ngumbo. It is "done for some new converts" in ten districts: Mporokoso, Mpulungu, Mweru, Mansa North, Kaputa, Nchelenge, Chienge, Kazembe, Isoka, and Senga Hill. They said that it is "done almost always for new converts" in eight districts: Kasama, Kawambwa, Kalungwishi, Lwena, Luwingu, Mbala, Chinsali, and Mwense. This activity is moderately done but it needs more emphasis.

Activity 9. Training and Equipping in Outreach Programs

In activity 9 , the pastors responded to the statement, "Churches train and equip new converts in outreach programs." The pastors said that training is "not done" in eight 
districts: Mansa South, Senga Hill, Bangweulu, Chembe, Chienge, Ngumbo, Isoka, and Nchelenge. It is "done for some new converts" in these nine districts: Mporokoso, Mpulungu, Mweru, Mansa North, Kaputa, Luwingu, Mporokoso, Nakonde, and Kazembe. It is "done always for new converts" in churches in seven districts: Kasama, Mwense, Lwena, Kawambwa, Mbala, Mpika, and Kalungwishi. This activity needs to be done more frequently as soon as new members are baptized.

\section{Activity 10. Marriage Enrichment Seminars}

In activity 10 , the pastors responded to the statement, "Churches conduct seminars to strengthen marriage and family." They reported that it is "not done" in six districts: Bangweulu, Kazembe, Chinsali, Ngumbo, Isoka, and Kasama. It is "done for some new converts" in ten districts: Mweru, Kaputa, Mpulungu, Nchelenge, Mansa South, Chembe, Kalungushi, Kasama, Luwingu, and Chienge. It is done "almost always for new converts" in eight districts: Kawambwa, Lwena, Mwense, Lwena, Mbala, Mpika, Mporokoso, and Mansa North. This activity is done moderately, it needs more emphasis.

\section{Activity 11. Free Vegetarian Cooking Classes}

In activity 11 , the pastors responded to the statement, "Churches provide diet nutrition and cooking classes for women." The pastors reported that it is "not done in eleven districts: Mweru, Kaputa, Nchelenge, Mansa South, Chembe, Kazembe, Mwense, Ngumbo, Bangweulu, Isoka, and Chienge. It is "done for some new converts in nine districts: Mpulungu, Mporokoso, Kalungwishi, Kawambwa, Luena, Mpika, Kasama, Luwingu, and Mansa North. It is "done always for new converts" in four districts: Kasama, 
Mansa North, Mbala, and Senga Hill. The pastors need to encourage churches to teach new members how to prepare vegetarian meals for their families.

\section{Activity 12. Church Members Open Their Homes}

In activity 12, the pastors responded to the statement, "Older members socialize with new converts. For example, new converts are invited by older members to have meals in their homes." The pastors reported that it is "not done" in ten districts: Mansa North, Mpulungu, Bangweulu, Kalungushi, Kazembe, Mwense, Ngumbo, Isoka, Kazembe, and Lwena. It is "done for some new converts" in eight districts: Kawambwa, Kaputa, Mansa South, Chembe, Mbala, Mpika, Mporokoso, and Chienge. It is "done almost always for new converts" in six districts: Mweru, Nchelenge, Mwense, Nakonde, Senga Hill, and Kasama. Pastors need to encourage older members to socialize with new members in their church.

Activity 13. Assistance in Overcoming Sabbath-Related Unemployment

In activity 13 , the pastors responded to the statement, "Churches encourage Seventhday Adventist business people to hire new members who have lost unemployment because of Sabbath problem." They reported that it is "not done" in twenty-two districts: Nchelenge, Kasama, Kawambwa, Kaputa, Mansa, Chembe, Mpulungu, Bangweulu, Kalungwishi, Kazembe, Mwense, Luena, Mansa North, Mansa South, Mbala, Mpika, Mpulungu, Morokoso, Mweru, Nakonde, Nchelenge, and Senga Hill. It is "done for some new converts" in two districts, Mweru and Chienge. No pastor reported that it is "almost always done for new converts" in any of the districts. This activity is not done very much and Adventist business people should be encouraged to hire skilled converts. 
Activity 14. Adventist Businesses Hire New Believers

In activity 14, the pastors responded to the statement, "Churches encourage Seventhday Adventist business people to hire new converts who are unemployed." The pastors reported that it is "not done." It is not "done for some new converts," or "done almost always for new converts" in any of the twenty-four districts. This activity is at its lowest level and Adventist business people should be encouraged to hire unemployed trained new converts.

\section{Activity 15. Joining Christian Clubs}

In activity 15 , the pastors responded to the statement, "Churches invite new converts to join different kinds of clubs run by church members." The pastors reported that it is "not done" in ten districts: Bangweulu, Ngumbo, Isoka, Kaputa, Kazembe, Luwingu, Mansa North, Mansa South, Mbala, and Nakonde. It is "done for some new converts" in five districts: Mpulungu, Kazembe, Nchelenge, Mporokoso, and Chienge. It is "done almost always for new converts" in nine districts: Nchelenge, Kasama, Kawambwa, Chembe, Kalungushi, Mwense, Lwena, Mweru, and Senga Hill. This activity is done moderately, but needs more emphasis to attract new converts.

\section{Activity 16. Assimilation}

In activity 16 , the pastors responded to the statement, "Churches encourage older members to build long lasting relationships with new converts." The pastors reported that it is "not done" in six districts: Mwense, Bangweulu, Chinsali, Isoka, Kaputa, and Kazembe. It is "done for some new converts" in seven districts: Nchelenge, Mansa South, Chembe, 
Luwingu, Mbala, Mpulungu, and Mporokoso. It is "almost always done for new converts" in eleven districts: Kasama, Kawambwa, Kalungulushi, Lwena, Mweru, Kaputa, Chienge, Mwense, Nakonde, Senga Hill, and Mansa North. This activity should be intensified to strengthen assimilation of new members.

\section{Activity 17. Invitation to Join a Small Group}

In activity 17, the pastors responded to the statement, "Churches invite new converts to join different types of small groups in the church." They reported that there were no districts were it is "not done." It is "done for some new converts" in nine districts: Kaputa, Chienge, Mpulungu, Bangweulu, Chinsali, Ngumbo, Isoka, Luwingu, and Kazembe. Fifteen districts reported that it is "done almost always for new converts" in Mwense, Kasama, Kawambwa, Kalungushi, Lwena, Mweru, Nchelenge, Mansa South, Chembe, Mbala, Mpika, Mporokoso, Nakonde, Senga Hill, and Mansa North. Although this activity is being promoted, some of the groups need to be introduced (see section on Existing Small Groups in the North Zambia Field). 
TABLE 4

RETENTION, ASSIMILATION, AND DISCIPLING OF NEW CONVERTS

\begin{tabular}{|c|c|c|c|}
\hline Activity & "Not done" & $\begin{array}{l}\text { "Done for some } \\
\text { new converts" }\end{array}$ & $\begin{array}{l}\text { "Done almost } \\
\text { always for new } \\
\text { converts" }\end{array}$ \\
\hline $\begin{array}{l}\text { 1. Warm welcome for new } \\
\text { believers }\end{array}$ & 0 & 10 & 14 \\
\hline 2. Fellowship dinners & 13 & 8 & 3 \\
\hline 3. Baptismal gifts & 22 & 1 & 1 \\
\hline 4. Mentors & 4 & 11 & 9 \\
\hline 5. New believers classes & 6 & 8 & 10 \\
\hline 6. Meeting felt needs & 6 & 15 & 3 \\
\hline 7. Small groups discussion & 15 & 4 & 5 \\
\hline 8. Individual counseling & 6 & 10 & 8 \\
\hline 9. Training, Equipping \& Outreach & 8 & 9 & 7 \\
\hline 10. Marriage seminars & 6 & 10 & 8 \\
\hline 11. Vegetarian cooking classes & 10 & 8 & 6 \\
\hline 12. Members open homes & 10 & 8 & 6 \\
\hline 13. Sabbath related unemployment & 22 & 2 & 0 \\
\hline 14. Adventist new hire believers & 0 & 0 & 0 \\
\hline 15. Joining Christian clubs & 10 & 5 & 9 \\
\hline 16. Assimilation & 6 & 7 & 11 \\
\hline 17. Invitation to join small groups & 0 & 9 & 15 \\
\hline Totals & 144 & 125 & 115 \\
\hline
\end{tabular}




\section{Summary}

Table 4 suggests that the churches of the North Zambia Field could do a lot more to retain, assimilate, and disciple new converts. The pastors reported that seventeen activities are "not done" (144) or "done for some" (125) at a far higher rate than those that there are "almost always done" (115). The churches need to be much more intentional about using these varied strategies.

\section{Activities for Spiritual Nurturing of New Converts}

Failure to spiritually nurture new converts is one of the reasons why newly baptized members drop out of the church. Fourteen activities were identified for spiritual nurturing of new converts. Pastors were asked "What actions are commonly taken in churches to provide spiritual nurture for new converts?" They were to indicate the frequency with which the following activities are taking place in their churches by stating that these activities are "not done," "done for some converts," or "done almost always for new converts." Following are their responses (see table 5).

\section{Activity 1. Topical Bible Studies}

In activity 1 , the pastors responded to the statement, "Churches conduct Bible studies for new converts covering topics of their choice." They reported that it is "not done" in seven districts: Kazembe, Bangweulu, Chinsali, Ngumbo, Mwense, Mansa North, and Mansa South. It is "done for some new converts" in eight districts: Chembe, Mpulungu, Kaputa, Mbala, Luwingu, Kawambwa, Lwena, and Kasama. It is "done almost always for new converts" in nine districts: Chienge, Bangweulu, Nchelenge, Mporokoso, Mweru, 
Mpika, Senga Hill, Mporokoso, and Kalungwishi. This activity is done moderately well but it needs more emphasis.

\section{Activity 2. Free Stop Smoking Programs}

In activity 2, the pastors responded to the statement, "Churches offer stop-smoking programs for new converts who have trouble stopping smoking." The pastors reported that it is "not done" in fifteen districts: Mwense, Mansa South, Chembe, Mansa North, Kazembe, Chienge, Nchelenge, Mporokoso, Kasama, Kazembe, Luwingu, Bangweulu, Chinsali, Ngumbo, and Kaputa. It is "done for some new converts" in six districts: Mpulungu, Nsenga Hill, Mbala, Mpika, Mpulungu, and Mweru. It is "done always for new converts" in three districts: Lwena, Kawambwa, and Nakonde. The pastors should encourage their churches to offer stop-smoking programs for new converts who have trouble stopping.

\section{Activity 3. Family Life Programs}

In activity 3 , the pastors responded to the statement, do churches "provide marriage and family enrichment programs?" The pastors reported that it is "not done" in four districts: Mwense, Bangweulu, Ngumbo, and Kazembe. It is "done for some new converts" in eleven districts: Mansa South, Chembe, Cheinge, Nchelenge, Mporokoso, Kaputa, Mpulungu, Kasama, Chinsali, Isoka, and Mbala. It is "done almost always for new converts" in nine districts: Mansa North, Mweru, Lwena, Kawambwa, Mpika, Nakonde, Luwingu, Senga Hill, and Kalungwishi. This activity is done moderately well, but it needs more emphasis. 
In activity 4 , the pastors responded to the statement, "Churches invite new converts to join prayer groups." The pastors reported that it is "not done" in ten districts: Mwense, Kazembe, Mansa South, Chembe, Chienge, Nchelenge, Kaputa, Kasama, Luwingu, and Mweru. It is "done for some new converts" in nine districts: Mporokoso, Mpulungu, Bangweulu, Mansa North, Lwena, Mansa South, Mbala, Mpika, and Kawambwa. It is "done almost always for new converts" in five districts: Kasama, Mweru, Nakonde, Senga Hill, and Kalungwishi. New converts to be encouraged to attend prayer meetings regularly.

\section{Activity 5. Regular Home Visitation}

In activity 5 , the pastors responded to the statement, "Church elders and deacons visit new converts regularly." The pastors reported that it is "not done" in three districts: Mwense, Nakonde, and Ngumbo districts. It is "done for some new converts" in thirteen districts: Chembe, Mansa South, Kazembe, Mansa North, Kaputa, Nchelenge, Chienge, Bangweulu, Mpulungu, Isoka, Senga Hill, Mpika, and Mweru. It is "done almost always for new converts" in eight districts: Mporokoso, Kasama, Kalungushi, Kawambwa, Mbala, Luwingu, Chinsali, and Lwena districts. Elders and deacons should be encouraged to visit their new converts regularly.

\section{Activity 6. Grief Recovery Support Groups}

In activity 6, the pastors responded to the statement, "Churches provide grief recovery counseling and support groups for those who have lost loved ones." The pastors reported that it is "not done" in eight districts: Mwense, Chembe, Mansa South, Kazembe, 
Mpulungu, Mbala, Isoka, and Kasama. It is "done for some new converts" in ten districts: Mansa North, Nchlenge, Chienge, Bangweulu, Mporokoso, Kalungushi, Lwena, Ngumbo, Chinsali, and Kawambwa. It is "almost always for new converts" in six districts: Kaputa, Senga Hill, Nchelenge, Mpika, Luwingu, and Mweru. This activity is foreign to the churches. However, if new converts are introduced to it they will appreciate it.

\section{Activity 7. Voice of Prophecy Courses}

In activity 7, the pastors responded to the statement, "Churches enroll new converts in the Voice of Prophecy Bible Course, Part Two, designed for newly baptized church members." The pastors reported that it is "not done" in eleven districts: Chembe, Kazembe, Mansa South, Mansa North, Chienge, Bangweulu, Kaputa, Ngumbo, Isoka, Mbala, and Mweru. It is "done for some new converts" in ten districts: Mpulungu, Kasama, Nchelenge, Mporokoso, Kalungushi, Lwena, Nakonde, Senga Hill, Mpika, and Kawambwa. It is "almost always done for new converts" in three districts: Mwense, Chinsali, and Luwingu. Pastors should encourage members to enroll new converts in Voice of Prophecy Part 2 Courses.

\section{Activity 8. Special Camp Meeting Programs}

In activity 8 , the pastors responded to the statement, "Churches have spiritual formation programs at camp meetings." The pastors reported that they are "not done" in five districts: Senga Hill, Kazembe, Mbala, Mpika, and Mpulungu. They are "done for some new converts" in four districts: Kaputa, Nakonde, Ngumbo, and Bangweulu. They are "done almost always for new converts" in fifteen districts: Chienge, Kasama, 
Mporokoso, Mweru, Nchelenge, Kawambwa, Kalungushi, Lwena, Luwingu, Mansa North, Mansa South, Mwense, Mbala, Chinsali, and Isoka. Spiritual formation programs at camp meetings could be intensified in the districts to strengthen the faith of new converts.

\section{Activity 9. Youth Training Programs}

In activity 9 , the pastors responded to the statement, "Churches provide Adventist youth training programs at their local churches." The pastors reported that there are no districts where it is "not done." It is "done for some new converts" in two districts, Kaputa and Ngumbo. It is "almost always done for new converts" in twenty-two districts:

Bangweulu, Chinsali, Chembe, Chienge, Isoka, Kalungushi, Kasama, Kawambwa, Kazembe, Luwingu, Lwena, Mansa North, Mansa South, Mbala, Mpika, Mpulungu, Mporokoso, Mwense, Mweru, Nakonde, Nchelenge, and Senga Hill. This is activity is well done; keep it up.

\section{Activity 10. Personal Testimonies}

In activity 10, the pastors responded to the statement, "Churches train new converts how to give personal testimonies." They reported that it is "not done" in five districts: Kaputa, Nakonde, Senga Hill, Mpika, and Ngumbo. It is "done for some new converts" in fifteen districts: Mweru, Nchelenge, Chienge, Kasama, Mporokoso, Mwense, Kazembe, Bangweulu, Lwena, Mbala, Isoka, Luwingu, Kawambwa, Kalungushi, and Mpulungu. It is "done almost always for new converts" in four districts: Mansa North, Mansa South, Chembe, and Chinsali. This activity is moderately done, but could be improved for the better. 


\section{Activity 11. Instruction in Christian Living}

In activity 11, the pastors responded to the statement, "Churches teach new converts practical ways of how to live by Christian principles." The pastor reported that it is "not done" in Kazembe district. It is "done for some new converts" in Kaputa district. It is "done almost always for new converts" in twenty-two districts: Mweru, Nchelenge, Chienge, Kasama, Mporokoso, Mwense, Kazembe, Bangweulu, Lwena, Mbala, Mpika, Isoka, Mwense, Mpulungu, Mansa North, Mansa South, Luwingu, Chembe, Chinsali, Senga Hill, Nakonde, Kalungushi, Kawambwa, and Ngumbo. This activity is moderately done but it needs more emphasis.

\section{Activity 12. Opportunities for Public Speaking}

In activity 12 , the pastors responded to the statement, "Churches provide training programs in public speaking." They reported that it is "not done" in eight districts: Kaputa, Mweru, Nchelenge, Chienge, Kawambwa, Chinsali, Mpika, and Mwense. It is "done for some new converts" in six districts: :Kazembe, Kasama, Ngumbo, Nakonde, Senga Hill, and Mpulungu. It is "done almost always for new converts" in ten districts: Bangweulu, Kalungwushi, Lwena, Luwingu, Mansa North, Mansa South, Kaputa, Mporokoso, Chembe, and Mbala. This activity is done moderately but needs more emphasis.

\section{Activity 13. Christian Witnessing Program}

In activity 13, the pastors responded to the statement, "Churches have a simplified Witnessing for Christ Training Program." The pastors reported that it is "not done" in fifteen districts: Senga Hill, Mbala, Kaputa, Mwense, Kazembe, Kawambwa, Kalungwishi, 
Lwena, Mansa North, Mansa South, Chinsali, Mpulungu, Mporokoso, Mwense, and Mweru. It is "done for almost some new converts" in five districts: Nchelenge, Nakonde, Mpika, Luwingu, and Lwena. It is "done almost always for new converts" in four districts: Ngumbo, Bangweulu, Chembe, and Chienge. This activity is not done regularly in the districts and needs more emphasis.

\section{Activity 14. Church Libraries and Resource Centers}

In activity 14, the pastors responded to the statement, "Churches have libraries that include Spirit of Prophecy books and other materials" for new converts to read. The pastors reported that it is "not done "in nineteen districts: Senga Hill, Kaputa, Mwense, Kazembe, Kawambwa, Kalungwishi, Lwena, Mpulungu, Nakonde, Chinsali, Mpika, Chembe, Chienge, Isoka, Ngumbo, Luwingu, Mporokoso, Nakonde, and Nchelenge. It is "done for some converts" in two districts: Mbala, and Bangweulu. It is "done almost always for new converts" in three districts: Mansa North, Mansa South, and Kasama. There seems to be few libraries in churches; pastors need to encourage each church to open a library for old and new converts. 
TABLE 5

\section{ACTIVITIES FOR SPIRITUAL NURTURING \\ OF NEW CONVERTS}

\begin{tabular}{|c|c|c|c|}
\hline Activity & "Not done" & $\begin{array}{l}\text { "Done for some } \\
\text { converts" }\end{array}$ & $\begin{array}{l}\text { "Done almost } \\
\text { always for new } \\
\text { converts" }\end{array}$ \\
\hline 1. Topical Bible Studies & 7 & 8 & 9 \\
\hline 2. Free Stop-smoking Program & 15 & 6 & 3 \\
\hline 3. Family Life Program & 4 & 11 & 9 \\
\hline 4. Prayer Meetings & 10 & 9 & 5 \\
\hline 5. Regular Home Visitation & 3 & 13 & 8 \\
\hline 6. Group Recovery Support Group & 8 & 10 & 6 \\
\hline 7. Voice of Prophecy Courses & 11 & 10 & 3 \\
\hline 8. Special Camp Meeting Program & 5 & 4 & 15 \\
\hline 9. Youth Training Programs & 0 & 2 & 22 \\
\hline 10. Personal Testimonies & 5 & 15 & 4 \\
\hline 11. Instructions in Christian Living & 1 & 22 & 1 \\
\hline $\begin{array}{l}\text { 12. Opportunities for Public } \\
\text { Speaking }\end{array}$ & 8 & 6 & 10 \\
\hline 13. Christian Witnessing Programs & 15 & 5 & 4 \\
\hline $\begin{array}{l}\text { 14. Church Libraries \& Resource } \\
\text { Centers }\end{array}$ & 19 & 2 & 3 \\
\hline Totals & 111 & 123 & 102 \\
\hline
\end{tabular}

\section{Summary}

Table 5 shows nurturing activities are "not done" in several districts (111). These activities need to be promoted in districts. Further, the table shows that nurturing activities are "done for some converts" in some districts (123). Finally, the table reveals that spiritual 
nurturing activities are "done almost always for new converts" in some churches (106). All these activities need to be intensified to raise the spiritual level of new members for retention purposes.

\section{Existing Small Group Ministries in Zambia}

There are some existing small prayer groups in the North Zambia Field which were started by Pastor Chansa and Pastor Mwenya in 2005 (see chapter 5 for details). In the survey ten questions were asked on small groups in general. Pastors responded by saying "yes," "no," or "not sure." See pastors' responses to nine (9) questions in table 6.

\section{Summary}

Table 6 shows that the level of interest of pastors in the small groups is very high, for the "yes" answers to nine questions on the able totals (133). The total number of those who said "no" is (11) and the not sure column was (0). This indicates that the pastors have some knowledge about small groups. They are also ready and willing to continue or start small group ministry in the churches. 
TABLE $6^{77}$

SMALL GROUPS IN CHURCHES IN 2005

\begin{tabular}{|l|c|c|c|}
\hline Question & Yes & No & Not Sure \\
\hline 1. Do you have small groups in your churches? & 16 & 0 & 0 \\
\hline 2. Do you know what small groups are for? & 13 & 3 & 0 \\
\hline $\begin{array}{l}\text { 3. Have you had basic training in small group } \\
\text { ministry? }\end{array}$ & 15 & 1 & 0 \\
\hline $\begin{array}{l}\text { 4. Would you like to start small groups ministry in } \\
\text { your churches? }\end{array}$ & 16 & 0 & 0 \\
\hline $\begin{array}{l}\text { 5. Would you like to learn more about small group } \\
\text { ministry? }\end{array}$ & 16 & 0 & 0 \\
\hline $\begin{array}{l}\text { 6. Do you think your church members would be } \\
\text { interested in small group ministry? }\end{array}$ & 15 & 1 & 0 \\
\hline $\begin{array}{l}\text { 7. Do you think small group ministry will help to } \\
\text { retain new converts in your churches? }\end{array}$ & 16 & 0 & 0 \\
\hline $\begin{array}{l}\text { 8. If small groups were introduced in your churches } \\
\text { would you be interested in training members how to } \\
\text { lead small groups? }\end{array}$ & 1633 & 11 & 0 \\
\hline $\begin{array}{l}\text { 9. Have you ever had training sessions of small } \\
\text { group ministries in your churches? }\end{array}$ & 10 & 0 & 0 \\
\hline TOTAL & & & 0 \\
\hline
\end{tabular}

${ }^{77}$ These nine questions on small groups were extracted from the Questionnaire for the North Zambia Field Survey of 2005-2006. 
Existing Small Groups in the North Zambia Field

The North Zambia Field already has eight types of small groups functioning. These are fellowship groups, Bible study groups, outreach groups, task/ministry groups, support groups, cell groups, and Sabbath school units. However, this dissertation proposes to add some additional small group types, such as, house churches, covenant groups, task/ministry groups, and support groups. Other aforesaid small groups need some improvements to reach acceptable levels for small groups.

Table 7 shows the total number of small groups and types of small groups exiting in the North Zambia Field as of December 31, 2006. 
TABLE $7^{78}$

TYPES OF SMALL GROUPS IN THE NORTH ZAMBIA FIELD

\begin{tabular}{|l|c|}
\hline \multicolumn{1}{|c|}{ Type of Small Group } & Number \\
\hline 1. Fellowship group (for spiritual and social interaction) & 30 \\
\hline 2. Bible study groups & 256 \\
\hline $\begin{array}{l}\text { 3. Outreach group (continuous witnessing groups to non-Christians, non-members, } \\
\text { or non-attending church members) }\end{array}$ & 259 \\
\hline 4. Task/ministry group (one-time group for specific task) & 1 \\
\hline 5. Support groups (for individuals with special needs, actually short-term) & 14 \\
\hline $\begin{array}{l}\text { 6. Prayer group (focusing on prayer, although there is also Bible study and } \\
\text { sharing) }\end{array}$ & 184 \\
\hline $\begin{array}{l}\text { 7. Covenant groups (groups that agree to meet for specific activities for specific } \\
\text { times, e.g., prayer group meeting once weekly for one year) }\end{array}$ & 0 \\
\hline 8. House church (meets for Sabbath and other services in a home) & 0 \\
\hline $\begin{array}{l}\text { 9. Cell church group (having the small group as the main component of church } \\
\text { activities }\end{array}$ & 27 \\
\hline $\begin{array}{l}\text { 10. Sabbath school action units (uses Sabbath School class as an existing small } \\
\text { group) }\end{array}$ & 602 \\
\hline TOTAL & 1373 \\
\hline
\end{tabular}

\section{Identifying the Main Inadequacies}

Having shown the scale of the membership dropout problem and surveyed its cause and attempted solutions, the time has come to identify the main inadequacies.

First, existing strategies for nurturing new members in their new-found faith are inadequate. The post-baptism lessons and instructions are not designed to help new converts to grow up and mature within the church community. As a result, new converts

${ }^{78}$ These ten types of small groups were extracted from the Questionnaire for the North Zambia Field Survey of 2005-2006. 
often do not forsake their former beliefs and practices. The new members often fail to wholeheartedly embrace their new found faith, the Sabbath truth, and the Spirit of Prophecy. Furthermore, pastors and their church members often fail in spiritually nurturing new members after baptism because they are-few in number and some pastors are not trained

Second, there are inadequate past and present strategies for assimilation or bonding of new converts. Older church members do not find time to visit and answer personal questions from new converts. When a new member has a Sabbath problem at the place of work, there is no one to give counsel or advise him or her. The church needs more effective strategies of bonding well-established Seventh-day Adventist families with new members.

Third, there are inadequate past and present strategies for training new converts in discipleship. In many churches there are no training programs in discipleship. In some churches training in discipleship is provided for the elite and the educated, while the majority of lower class people, which is comprised of new converts in villages and towns, are left out. Many of the new converts who dropped out of the church complained of lack of training for discipleship. They were not allowed to participate in discipling others.

Fourth, there are inadequate strategies for providing pastoral care to new converts. The new members are not visited regularly by the pastor. The pastor has many churches and companies to visit and he often visits the churches and companies once a year. There are no immediate plans that the situation will change for the better. Many of the converts who left the church complained of lack of pastoral care.

Fifth, there are inadequate past and present strategies for Sabbath programs. For example, Sabbath School lessons, Sabbath morning sermons, and Sabbath afternoon Bible 
studies, presented for two hours every Sabbath afternoon, deal mainly with topics that are helpful to older church members. In fact, at the present moment the church has no plans in place for new members to become attached to older church members who could mentor them. As a result, some of these new members are likely to go back to their former church affiliations or will have their names dropped from church records for Sabbath breaking, committing adultery, or any other violation of the Ten Commandments.

This dissertation suggests that it is possible to reverse and change this present situation for the better through small groups in the churches. If this could be done, most of the members will stay and contribute to the progress of the church. It is possible for the church to minister effectively to their needs, keep them well nourished, and care for them in small group settings.

\section{Advantages of Small Groups for Building Long-Lasting Relationships}

There are several advantages of small groups for retention of membership as implied by past practices in the North Zambia Field. Nine of the advantages are brought out in this dissertation.

First, small groups can provide biblical and lifestyle education at an appropriate level for new members. New members learn well at a seminar that is designed for them. Bible truths and healthful living principles, lifestyles, and reading and writing can be better learned in a small group setting. For example, members who are experiencing personal problems, how to stop smoking, drinking, etc, can be helped to quit faster in a small group. This is so because small groups can address the need immediately if it is identified, and if 
they are not able to do that, they can address the church leaders or go to the pastor for help. If the need requires a professional, it can be referred to a professional in their group or in the church. In fact, a new convert is more free to talk to one person in the group whom she or he can confide in rather than take the whole matter to the entire church to find a solution to his or her problem.

Second, small groups can teach new members Christian spirituality. New members can learn in a small group how to live by Bible principles. They can be taught how to study the Bible, use the Sabbath school study guide, pray, and how to live in peace with all people. It is much easier for new members in a small group to learn principles of Christian spirituality using a program like Cole's Life Transforming Group System. Neil Cole says, "It is simple, yet powerful. It incorporates the values of community, life transformation and reproduction of disciples." ${ }^{.79}$

Third, small groups can facilitate the building of long and lasting relationships within the whole church family. This is a reason that causes newly baptized members to drop out or leave church and can be adequately addressed by small groups. Where small groups are introduced, it is possible that older members and church leaders can build long and lasting relationships with new members in small groups. For example, if a new convert joins a small group he or she "were in our similar age group, shared common life experiences, had the same life goals, worked on the same projects, demonstrated an

\footnotetext{
${ }^{79}$ Neil Cole, Cultivating a Life for God: Multiplying Through Life Transforming Groups (Carol Stream, IL: ChurchSmart Resources, 1999), 70.
} 
attractive personality, and had a common need." ${ }^{\prime 80}$ These matters can help to build long and lasting relationships between older members, leaders, and new converts.

Furthermore, one of the purposes of a small group is to build relationships between people. David Cox says that small groups "connect people relationally in groups (four to ten individuals) for the purpose of growing in Christlikeness, loving one another, and contributing to the work of the church, in order to glorify God and make disciples of all nations. ${ }^{" 81} \mathrm{He}$ continues to say that small groups are "committed to building positive, deep and long and lasting relationships between individuals through a more relational approach to Bible study and prayer." $" 82$

Fourth, small groups can provide guidance to members in practical matters so that older members do not act like police who catch new converts in violation of the Ten Commandment and church standards. In small groups both older members, leaders, and deacons are taught "Christlikeness, loving one another ..." and to "grow in our relationships with each other." community. ${ }^{984}$ Furthermore, small groups' members "can be devoted to each other"

\footnotetext{
${ }^{80}$ Haggard, 37.

${ }^{81} \operatorname{Cox}, 22$.

${ }^{82}$ Ibid., 23.

${ }^{83}$ Ibid., 22-23.

${ }^{84}$ Gorman, 23.
} 
(Rom 12:10) learn "to honor one, another," "accept one another" (Rom 15:7), "encourage each other" (1 Thess 4:18), "build each other" (1 Thess 5:11), and many more. ${ }^{85}$

Fifth, small groups can provide mentoring for new converts. New converts need mature members to mentor them. It is possible to assign a mentor to each of the new converts in a small group. It is also easier to identify someone who needs a mentor in a small group than in a large congregation in the church. Small groups emphasize the need to "serve one another" (Gal 6:2), "instruct one another" (Rom 15:14), "carry each others burden" (Gal 6:2), to "be patient, bearing with one another in love" (Eph 4:2), and to be kind and compassionate to one another" (Eph 4:32).

Sixth, small groups can identify spiritual gifts and provide training for their use. One of the objectives of the small group is to make disciples, "Go, then, to all people everywhere, and make them my disciples; baptizing them in the name of the Father, the Son, and the Holy Spirit, and teach them to obey everything I have commanded you" (Matt 28:19, 20). Small groups

make disciples. At least, that is the objective, which Jesus commissioned His own disciples to do (Matt 28:19,20). A disciple by definition is a fully committed follower of Christ, so we become disciples from the day we decide to follow Jesus, and we remain disciples throughout our lives. At no point will we ever feel that we measure up to all that we know we ought to be but at every. point we can be fully committed to following $\mathrm{Him}^{86}$

Small groups also have new members identify their gifts so that they can be placed in appropriate ministries, for in small groups "spiritual gifts are readily identified, developed

\footnotetext{
${ }^{85}$ Ibid., 30.

${ }^{86}$ Ibid., 39.
} 
and used"87 in the church, and the community. Small groups are known for "the way they help to identify and develop spiritual gifts" ${ }^{988}$ in their members. So it can be seen that small groups can help new converts to identify their gifts and have them placed in appropriate ministries after their baptism based on their spiritual gifts.

Seventh, small groups can increase the participation of new members in the life of the church. The establishment of small groups can moderate the dominance of "family churches," where one or two families control and lead out in all phases of church programs, making it hard for new members to participate. One of the objectives of a small group is to "build Christian community." $" 89$ Cox writes, "If there is one thing the modern world yearns for more than anything else, it surely has to be a sense of belonging, a sense of community." The perpetrators of "family churches" will learn in their small groups to live in peace with their fellow members and also to love and respect views of other people. The church does not belong to an individual; it belongs to Christ who paid the price for it on the cross (Eph 5:25).

Eighth, small groups can offer particular support and guidance for young people as they select spouses or live with unbelieving spouses. Young people who marry unbelievers usually drop out of the church or go missing "to please the unbelieving spouse or to live

\footnotetext{
${ }^{87}$ Ibid., 43.

${ }^{89}$ Ibid.

${ }^{90}$ Gorman, 83.

${ }^{91}$ Ibid.
} 
with unbelieving spouses." ${ }^{\prime 91}$ Young people in the districts can be taught or instructed in family life lessons in small groups on how to choose a partner (1 Cor 7:14). Myrna Tetz and Gary Hopkins share this observation on how to keep the young people in the church. They say that "the way to keep young people in the Seventh-day Adventist Church is to surround them with adults who acknowledge them by name, display loving, caring attitudes toward them and show concern for them and help them whenever possible."92

Ninth, small groups can provide guidance to prevent members from being attached to offshoot groups. Offshoot groups are made up of former members who left the Seventhday Adventist Church because of differences with leaders or doctrines of the church. These backsliders from the church sneak into Adventist churches in some districts and go about indoctrinating members of the church with their wrong interpretation of the Bible and doctrines of the church without permission from the pastor or church elders. They appeal to church members to leave the church and join them in their fight against the Seventh-day Adventist Church. It can't be done because small groups encourage members to study the Bible seriously for "relational Bible study attempts not only to lead the group to a better understanding of Bible messages, but to encourage every member of the group to relate that message to their personal lives in practical and personal ways. ${ }^{.93}$

${ }^{92}$ Pastor Laban Mwenya, "Mwense District Pastor's Report," August 2, 2006.

${ }^{93}$ Myrna Tetz and Gary L. Hopkins, We Can Keep Them in the Church: How to Love Our Children So They Won't Leave (Nampa, ID: Pacific Press Publishing Association, 2004), 12.

${ }^{94} \operatorname{Cox}, 40-41$. 
For example, Western countries have found out that a small group is a powerful tool in member retention. They have utilized small groups for spiritual nurturing, social assimilation, training for discipleship, and pastoral care in their churches. Cloud and Townsend say that "through participating in small groups, leading them, training their leaders, consulting for them, and researching them, we have come to believe that a small group is without a doubt one of the most powerful tool of life change and spiritual growth." ${ }^{\circ 94}$ This dissertation is suggesting that small group ministry is the answer to inadequate strategies, if only they are empowered to develop new adequate membership retention strategies.

\section{Summary}

Chapter four has briefly discussed the growth patterns of the North Zambia Field. The main people groups were introduced and traditional practices were presented. The history of how Adventist missionaries from South Africa came to Zambia and how the present North Zambia Field developed was outlined. Evangelistic methods and membership patterns were summarized. Chapter 5 will propose a model for using small groups to enhance new member retention in the North Zambia Field.

\footnotetext{
${ }^{95}$ Cloud and Townsend, 14.
} 


\section{CHAPTER 5}

\section{A SMALL GROUP MODEL FOR MEMBERSHIP RETENTION IN THE NORTH ZAMBIA FIELD}

This chapter discusses a small group model for membership retention in the North Zambia Field. The following aspects are presented: new member retention, assimilation of new members, spiritual nurture, serving members in need, training new members for discipleship, and providing pastoral care.

A "model" is a design or a plan. ${ }^{1}$ This dissertation is proposing a model or plan using small groups to enhance membership retention. The model is based on the Bible, Spirit of Prophecy, small group literature, theoretical support in behavioral sciences, and lessons learned in the past in the North Zambia Field. The model is intentionally contextualized for realities of the North Zambia Field. The desire of the author is that the "model" as a plan will prove so successful and effective that it will become an example for the Zambia Union Conference.

${ }^{1}$ H. W. Fowler and H. G. Fowler, The Concise Oxford Dictionary of Current English, $8^{\text {th }}$ ed. (Oxford: Clarendon Press, 1992), 762. 


\section{Small Groups in the General Zambian Context}

In the Chibemba language akabungwe is translated as "a small group or gathering of a few people."2 Small groups of various kinds play an integral role for all the tribal groups of Zambia. Despite belonging to different tribes, Zambians discuss ideas, sort out problems, meet in traditional gatherings, and in the village councils in small groups. Yet, Zambians do not think much about small groups or give them a precise definition. A small group in the Zambian context is simply a group of a few people, without the definition of size. This dissertation proposes a small group model that builds on traditional Zambian small groups, but goes beyond to offer more definition, education, and reorganization.

The Zambian traditional groups are based on: age, gender, language, marital status, and service organizations. Zambian culture has various age-specific small groups. These groups traditionally play the role of providing a training ground where same age boys, men, women, and girls can learn skills and prepare for adulthood and marriage. For example, men and boys learn how to hunt, fish, skills on solving personal problems, play different traditional games, such as the Nsolo (snakes and ladders) game. The women and girls learn skills in cookery, smearing of house floors, collecting firewood, and how to raise children.

${ }^{2}$ E. Hoch, Bemba Pocket Dictionary (Ndola: Zambia Mission Press, 1992), 34, 40. 


\section{Small Groups in the Zambian Church}

In the church context, age-specific small groups which will be formed in churches will play the role of a training center where men, boys, women, and girls will learn skills in witnessing for Christ, how to study the Bible, stopping bad habits such as smoking and drinking alcohol, etc. They will learn how to sing, conduct evangelistic meetings, etc. Some of the new members in the age-specific groups will be members of new small groups in churches.

Traditionally, Zambians form and organize groups according to gender to meet the needs of people in villages. The small groups, according to gender, play a leading role in initiation of both male and female in all ways of life. Men will form small groups with men to teach fellow men how to behave at funerals, make handles for spears, axes, etc. Women will form small groups with women, girls will form small groups with girls and teach each other cleaning of the house and laundry.

In the church context, the gender small groups which will be formed in churches will play the role of a uniting and training ground where established members will, in small groups, teach new member fellowship, Bible study, and evangelism. Some of the members of the gender small groups will join new small groups. The newly formed small groups will start functioning as soon as they are organized, with trained leaders to lead them. These small groups will meet in homes, church buildings, work places, and other convenient locations.

Small groups according to marital status (married couples or singles) are formed for men and women in villages and towns in Zambia. These small groups are focused on 
initiation of men and women in all aspects of life, e.g., raising of children, acquiring skills, and community service, etc. The churches will form new small groups where new members attend marriage enrichment seminars, counseling, raising of children, and home craft.

Small groups are formed according to languages, such as Tumbuka, Bemba, Mambwe, and Lungu. These small groups exists in North Zambia Field to promote communication, planning, oneness, belongingness, and association purposes. These small groups are not meant for promotion of tribalism.

Churches will form small groups according to languages to meet the needs of some members who do not speak and understand English (the official language) to promote communication, interaction, and association. Some of the members of different language groups will join new small groups. These small groups will meet in homes and other convenient locations for their group activities.

There are existing service small groups organized by the government ministry of social welfare services at welfare centers to train men and women in villages to care for the elderly people, the sick, and provide fire extinguishing service in villages, etc. The Seventh-day Adventist Church has various service groups such as the Dorcas Society, Adventist youth organization, Adventist men's group, Sabbath School department, and camp meeting committees. These small groups are not similar to the small groups being discussed now, for they differ in their focus, mission, covenant, and life span. Some of these small groups last only for a short time. However, the North Zambia Field churches 
will make provisions for members who are willing to incorporate their small groups or form new small groups out of their service small groups.

Wherever members are able to, the churches will organize task-oriented small groups and elect leaders to enable their small groups to provide different services in villages and towns. For example, the Dorcas society will form small groups that will care for the sick, clean old peoples' homes, etc. Adventist men will form small groups that will provide free services, such as repairing doors, thatching grass-roofed houses in villages, etc. Sabbath school classes will form small groups to teach new members to read, write, etc. Camp meeting committees will form small groups to teach fire extinguishing skills during camp meeting period to avoid fires, assist campers to construct shelters, etc. Adventist youth will form small groups to guard the campers during the camp meeting time for free.

Several small group types will be formed in the North Zambia Field to cater to anyone regardless of age, gender, marital status, etc. These new small groups (see types of small groups as described in the section about different varieties of small groups on p. 30 and 139) will be available at the local church for anyone to join. Their focus will be on mentoring, assimilation, service, training and discipleship, pastoral care, and new member retention.

All the new small groups will adopt a new meaning of a small group for a better understanding and smooth operation of small groups in churches. They will adopt McBride's definition of a small group: “A voluntary intentional gathering of three to 
twelve people regularly meeting together with a shared goal of mutual Christian edification and fellowship."3

\section{Existing Small Groups in the North Zambia Field Churches}

There are already some small groups in the local churches of the North Zambia

Field. A survey given to pastors in the North Zambia Field revealed that there are some existing small prayer groups in churches which were introduced in 2005 by field administration upon recommendation of the Zambia Union Conference.

Small prayer groups were initiated after Pastor Rogers Chansa (Field president, 2004-2007) returned from a one-week seminar on small prayer groups in churches organized by Southern African Indian Ocean Division officers, at Zambia Union Conference headquarters in Lusaka, October 10-17, 2005. Pastor Chansa conducted a one-week seminar at the North Zambia Field headquarters in Mansa town. A total of five hundred people, including sixteen pastors and their church elders, attended the meeting at Mansa from December 6-12, 2005. Pastor Chansa and Pastor Bright Mwenya led out at this one-week seminar for small prayer groups based on Col 4:4. The goal of this seminar was to urge churches to form small prayer groups in the North Zambia Field. ${ }^{4}$ As an example to the churches, a small prayer group at the North Zambia Field headquarters,

${ }^{3}$ McBride, Real Small Groups Don't Just Happen, 12.

${ }^{4}$ Pastor Rogers Chansa, President; Isaac Kaputo, North Zambia Field Secretary; and Pastor Sinyangwe, Ministerial Secretary, telephone interview with the researcher, May 27, 2006. 
made up of pastors and office workers, was organized on December 12, 2005, during the seminar.

After the Mansa seminar, Pastor Chansa and Pastor Mwenya went to conduct seminars in twelve of the North Zambia Field districts. The two pastors began conducting seminars from the beginning of January to the end of June 2006. They conducted meetings in Nchelenge ( 300 leaders/members attended), Kawambwa (250 leaders/members attended), Mwense (250 leaders/members attended), Kasama (300 leaders/members attended), Luwingu (120 leaders/members attended), Mpika (200 leaders/members attended), Nakonde (400 leaders/members attended), Mpulungu (500 leaders/members attended) Mbala (300 leaders/members attended), Samfya districts (350 leaders/members attended), and Chinsali (200 leaders/members attended) districts. ${ }^{5}$ After these Field-wide seminars were over, the local district pastors continued to conduct short, basic training seminars on small prayer groups.

The small prayer groups which were introduced by Pastor Chansa and Pastor Mwenya are patterned after Epaphra's prayer ministry based on Col 4: 4. Members meet to pray for themselves, others, ministers of the gospel, and church workers. Members of small prayer groups meet at different locations for their group meetings. Some meet at church, at homes, and other convenient locations. Currently, new small prayer groups have been formed focused on prayer and also doing fellowship, outreach, and supporting activities in churches of the North Zambia Field. There are 30 fellowship groups, 256

${ }^{5}$ Ibid. 
Bible study small groups, 259 outreach groups, 1 task/ministry group, 14 support groups, 184 prayer groups, 27 cell groups, and 604 Sabbath Action Units. ${ }^{6}$

\section{The New Small Groups Model}

The author commends Pastors Chansa and Mwenya for the wonderful work they did in the North Zambia Field. However, small groups need sustained promotion and training of leaders or else they will die out. The author proposes to build on what these two pastors have done by offering additional promotion, education, and organization. So far, small groups have been introduced in twelve of twenty-four districts. The author is proposing to introduce and promote new small groups in twelve other districts which were not visited and continue promotion and education where small groups are already functioning.

This dissertation also suggests that what will be needed now is to give (1) a fresh focus, (2) intensify small group promotion and education, (3) draw a master plan, (4) improve, grow, and expand existing small groups (fellowship groups, Bible study groups, outreach groups, support groups, prayer groups, cell groups), and (5) define the new and introduce other types of small groups (such as, covenant groups, house churches, task/ministry groups, and cell groups).

The small group program proposed in this dissertation will have several steps: (1) formal acceptance of a master plan for small groups, (2) a mission statement will be sought by the Field, (3) each district will have a small group master plan and mission

${ }^{6}$ Total number of some existing small groups in North Zambia Field are from the Questionnaire in chapter 6. 
statement, and (4) each church will have a small group master plan, mission statement, revival meetings, training of leaders, and the opening of pilot small groups. A pilot scheme will be necessary only for the four or more new small groups in the master plan and in the twelve districts not visited.

A one-year small group master plan for the North Zambia Field will be made and adopted by the North Zambia Field committee. The focus of existing small groups was on prayer. The new master plan will focus mainly on improving retention of new members and increasing the membership of existing small groups. The master plan will include plans and goals for the number of small groups, training seminars, and membership retention.

After the master plan has been voted, the small group mission statement for the North Zambia Field will be drawn and voted by the North Zambia Field committee at their year end committee meetings and a copy will be given to each of the eight or more district pastors at the year-end workers' meeting. This copy of the mission statement will be explained to pastors by field officers at the year-end workers' meeting.

When local church pastors go back to their year-end district councils, they will draw one-year master plans for the districts following the procedure used at the North Zambia Field office. The pastors, with the help of the local church and small group leaders, will draw up a one-year small group master plan in the local churches. Furthermore, the local church pastors will go to individual churches in the district to draw up and vote for a small group mission statement, with the help of the small group leaders. After the church has voted its mission statement, it will be put in a picture frame and 
hung somewhere in the church where it can be seen. Following is a sample of a small group mission statement for the local church:

To connect people relationally in groups of four to [three to twelve] ten who come together on a regular basis for the common purpose and are led by an identified leader who is assisting them in their progress towards full devotion to Christ by intentionally providing an environment for connection, community, and spiritual formation. ${ }^{7}$

\section{Preparation and Training of the Church}

Small groups are hard to start and hard to keep going, therefore, the church members' attitudes, assumptions, skills (such as listening), knowledge, and commitment are part of the process of change for small groups to succeed. The church has to be prepared before organizing small groups in the church. The members' attitude has to change and the assumptions about small groups have to be realistic. The members will be trained to acquire new skills and knowledge. The leaders and members will make a commitment to join small groups and to serve God.

The church small group program will open with a one-week revival meeting, conducted by the local church pastor. The revival meeting will start on Sunday evening and end on the Sabbath day. A business meeting will take place the following Sunday to draw up and vote the mission statement of the church. After the business meeting, the church board will meet to elect the elder responsible for small groups. Then, the local

${ }^{7}$ Bill Donahue, Leading Life-Changing Small Groups (Grand Rapids, MI: Zondervan Publishing House, 1996), 21. 
church will organize and vote in a pilot small group. After the pilot small groups have been voted in, small group leaders and coaches will be elected.

The elected small group leaders and coaches will be trained by the local pastor for a week. At the end of their training, the local pastor will dedicate the new small group leaders on Sabbath afternoon and the pilot small group or groups will start functioning or operating immediately at each of the local churches.

A suggested seminar program for a one-week seminar for either the church or the district will be thus: The seminar will begin on Sunday and end on Friday evening. The daily program will start at 6:00 p.m. with a song service lasting five to ten minutes. This will be followed by question time for fifteen minutes, and ends with a lecture for fortyfive minutes.

Pilot Small Groups Formed in Churches in the North Zambia Field ${ }^{8}$

Each of the churches in twelve districts of the field will start with one to four pilot small groups at the local church. These pilot small groups will go through all the phases of a small group. After one or two years, the pilot small groups will disband and each member of the group will form a new small group with three to twelve new members. Before the new groups start functioning, the local pastor will conduct training for the new small group leaders.

${ }^{8}$ When existing small groups were launched by Chansa, pilot small groups were not introduced because at that time the focus was only on prayer. When sought on whether it would be of benefit to launch pilot small groups in the new program, Pastors Chansa and Mwenya, in a telephone interview with the author, advised that it was the right thing to first start with a pilot small group (February 24, 2006). 
The following handbooks will be used for the small group leaders training program: (1) Bill Donahue, Leading Life Changing Small Groups, (2) Jeffrey Arnold, The Big Book on Small Groups, (3) Kurt W. Johnson, Small Groups for the End-time, (4) Neal F. McBride, How to Lead Small Groups, and (5) Neal F. McBride, Real Small Groups Do Not Just Happen.

To continually increase the number of small groups in the North Zambia Field, the life span of a small group will be one to two years. This will be explained when new groups are formed and the plan for expansion will be part of the leadership training.

The small groups will follow a timetable of meetings in the local church. Small groups, once organized and operational, will be meeting once, twice, or three times a month. The members of each small group will choose a day and time for their meetings. At this meeting, the members will study books, pray, study the Bible, plan, or do their projects, etc. The small group members will discuss and choose one of them to lead out in activities and discussion. The typical timetable for the meeting of small groups in churches in the North Zambia Field will be as follows.

A small group daily meeting program will start at 5:30 p.m. with a three-minute prayer followed by remarks by the leader for ten minutes. It will continue with a discussion on a book or Bible study for forty-five minutes, and close with a prayer.

It will be possible for the small group ministry to succeed as a model or as "a design or a plan"9 for mission in the North Zambia Field because the questionnaire given

${ }^{9}$ Fowler and Fowler, 762. 
to local pastors revealed that the members are interested in small groups and their local pastors are anxious to train them.

\section{The Structure and Organization of Small Group Ministry}

The organizational structure of small groups ministry will be as shown in the Organizational Chart. At the Field level, the committee will appoint a departmental director to be responsible for small groups. He will report to the Field Committee on the progress and goals of the small group ministry, according to the master plan of the Field. At the church level, the church board will form the Small Group Ministry Committee that will be responsible for all the promotions and activities of the small groups. The committee will supervise the activities of all small groups, coaches, and leaders. See the organizational chart (appendix E) on page 239.

\section{Purposes of Small Groups}

The Small Group Committee at the local church level will organize and form subcommittees to cater to the promotion of different types of small groups and their related activities. For example, the local church will form a sub-committee for assimilation, a sub-committee for pastoral care, etc. The sub-committee for assimilation will enable the process to become more effective. The small group leaders, pastor, and church elders will see that the sub-committee of assimilation leads out in the assimilation programs of the local church. The members of the committee in the church will be responsible for small groups, to see that small group leaders are familiar with the assimilation program of the church, and to see that new group leaders are trained, given the necessary handbooks, 
and that groups are meeting regularly. They will see that problems of small group members are attended to by the right persons. For example, members who do not have Bibles are provided with some, those who do not attend meetings regularly are visited. The assimilation committee will see that members of small groups who are weak spiritually are attended to by the elder, small group leader, or pastor.

The small group committee will also encourage every church member to join the small groups and assist in choosing leaders and mentors for new members. The main purposes of small group ministry in North Zambia Field will be to assimilate, provide spiritual nurture, provide service, discipleship, and pastoral care to new members.

\section{Developing Small Groups for Assimilation}

In the Zambia tradition, a new resident or residents are assimilated by being introduced to the people in the village by the headman. After introductions, each family invites the new family or individual for a meal in their home. The process of assimilating newcomers into the village involves everyone, men, women, boys, girls, until former newcomers can talk, eat, and chat freely with anyone in the village. Effective new member assimilation in the Zambian context must follow the customary pattern as seen in village life.

One of the crucial roles played by the small groups in this model is the assimilation of new members into the fellowship of the church. In general terms, "assimilation" means "bringing into conformity, absorb or incorporate."10 In the

${ }^{10}$ Lesley Brown, The New Shorter English Dictionary on Historical Principles (Oxford, UK: Clarendon Press, 1993), 1:131-132. 
particular context in the church, assimilation means conforming to expectations, absorbing the essential qualities of the church, and becoming incorporated fully into the body of Christ.

1. For the purpose of assimilating new converts into the church, the pastor will work with the welcome committee, church elders, small group leaders, mentors, interestcoordinators, counselors, individual members, small group members, and others.

2. After baptism, the welcoming committee will hold a special meal for the newly baptized small group members and new members to assimilate them into the church. This meal will be hosted by the pastor, elders, deacons, and deaconesses. The church choir and quartet will provide music and new members will line up in the front of the church after their baptism and old members of the church will shake hands with them to extend a hand of friendship and welcome into the Seventh-day Adventist Church. Some of the new members will be asked to give their personal conversion testimonies.

At this meal, the pastor will introduce the small group leaders, church officers, departmental directors, deacons, and deaconesses to the new members. The small group leaders will, in turn, invite newly baptized members to join small groups and various departments of the church. The departmental directors and small group leaders will talk to the new members, inviting them to join their departments and their small groups. As a means to absorb new members in the church, the pastor and the elders, after the meal is over, will give out new Bibles, study guides, Spirit of Prophecy books, other religious books, and the church manual, to the newly baptized members. 
3. The pastor and elders will take a leading role in the assimilation of newly baptized members into small groups to "bring into conformity, absorb or incorporate" them by orientation and by following certain steps. The pastor and the elders will gather new members to orient them as to the church structure, hierarchy, use, and purpose of the church services. For example, the Lord's Supper, baptism, church board, business meeting, etc. The pastor and elders will speak to each of the small groups about church ordinances of their choice. For example, elders will speak about the Lord's Supper and the pastor on the church hierarchy.

Pastors, small group leaders, church leaders, and members will lead by example in word and deed. The pastor, small group leaders, and church elders will encourage church leaders and older members to lead by example in their church work, discussions, promises, behavior, and communication with the new members. He will advise them to conduct themselves in their association with new members in a Christian manner, so that new members will able to see a Christlike character in them.

The pastors, professionals, and elders will work out a program to give new members something to do in the church. To assimilate the new members in the church, the pastor and the elders will invite new members to participate in the church business, etc. New members will be asked to come and do some manual work at the church, join the old members to do community service work, or -assist at an evangelistic effort as ushers, deacons, or deaconesses, etc.

4. The pastors and other professionals will provide an on-going training program for small group leaders and members of small groups to equip and prepare them to face 
new changes and techniques in the assimilation processes. The pastor and other professionals will conduct marriage seminars, leadership of small groups courses, training in how to give Bible studies, witnessing for Christ, and cooking classes for new members. These skills will empower new members to serve the Lord in various capacities in the church. New small group members will be able to select areas in which they are gifted so that, once they are trained, they can operate effectively. The pastor and the church will arrange training programs to take place at the beginning of each year after the church elections. This arrangement will enable newly elected church officers and leaders to start their work at the beginning of the year without fear of failing.

Training is an effective tool in assimilation of new members. The pastor and the church will speed up assimilation of new members of small groups in the churches by training adequate mentors. The church will always keep a pool of mentors for assimilation purposes of new members joining the church after evangelistic efforts, revival meetings, baptism, transfers, etc.

Special classes for new church members will be put in place. To facilitate the assimilation process of new small group members into the Seventh-day Adventist Church, the pastor and the elders will arrange classes for newly baptized members. These classes will run for one full year to teach new members the doctrines and services of the church. New members will be encouraged to ask questions where they need guidance.

The four reasons why new members in the North Zambia Field will be enrolled in a special class for the first year where their leaders will guide them are: (1) "in the 
discussions of the key texts in the lesson, keeping the spotlight on the Word of God, (2) to keep the pages turning, having class members read key discussion texts, (3) to listen to God's ideals first, and the share your thoughts and feelings, (4) and impress upon new members the need for humble dependence upon the Holy Spirit for rightly discerning the truth and for strength to live in it in a manner that will please and glorify God."

The pastor and elders of the church will appeal to old members and church leaders to provide a safe growth environment for new members. To assimilate new members into the church, the old members will take steps to see that they do not discourage new members by speaking evil of them or acting as if they were policemen to new members. Old members will do what they can to see that they provide a growing environment for new members by loving, caring for, and sympathizing with them

5. Mentors in small groups will assist in the assimilation process by mentoring or teaching new members of small groups and reporting to the church those members who are not attending church meeting to see what can be done to improve the situation. The pastor and church leaders will look into other problems affecting new members with a view to help them. For example, those new members who are still smoking, drinking beer, working on the Sabbath, etc.

6. The interest coordinator will speak to small group members on new interest records and the church clerk will talk to new members about church records and transfers. First, the interest coordinators and church clerks will collect information from the new

"E. Daniel Caslow, Discipling New Member Ministry (Mountain View, CA: Pacific Press, 1982), 27-28. 
members. This information will contain the names and addresses recorded by the clerk in the church record file and stored in the safe at the office. The interest coordinator will collect simple information, e.g., residential address, postal address, telephone numbers, and email address of each and every new member. The coordinator and clerk will implement the assimilation process by staying connected with new members.

The system of appealing to new members to join small groups and gathering and tracking data for new members will be ongoing after the evangelistic effort, revival meeting, and transfer in of new members. The churches will also evaluate the progress of new members in their Bible classes and small groups to see what new members need spiritually and physically.

7. Individual established church members will assist in the assimilation process of new small group members in their neighborhood by visiting them regularly and communicating with them. Older members in the church will start building relationships with new members. Members will build relationships with new members by inviting them for meals in their homes and inviting them to join their clubs. For example, golf clubs, tennis clubs, gym, soccer, etc.

The members in the church will be invited to a special meeting with the newly baptized small group members. The pastor and elders or the committee will arrange for special meetings in the church hall for new members to meet and socialize. New members will meet with older members to socialize in meetings such as New Year celebrations, Independence Day celebrations, Christmas parties, wedding parties, bridal showers, engagement parties, funerals, Mother's Day celebrations, and Father's Day 
celebrations. The older members of the church will be patient, humble, and caring when dealing with new members.

Needs of new members in small groups will be attended to by small groups/ individual members. The pastor/s and elders will make provision, where possible, for members' needs to be attended to by the small group or certain members of the church. For example, the spiritual needs of new members will be attended to by the church, such as equipping and training for service in the church. Other needs will be attended to by individual members of the church, such as building relationships, loving one another, and caring for each other.

8. The church will facilitate the assimilation of new members in the small groups by providing the following:

A forum or club will be formed in the church to assimilate new small group members. The pastor, elders, and small group leaders in the North Zambia Field will come up with a forum or club for new small group members to express their concerns in their lives and in the church. For example, new members who have lost their jobs because of Sabbath problems and Sabbath keeping. Can the church leaders ask some church members who are owning or running companies or business organizations to employ some new members? Other concerns may be those who are being harassed by members of their families because of joining the Seventh-day Adventist Church. For example, children, spouses of non-Adventists, and non-Adventist employers.

A church counselor in small groups will be engaged by the church to help those new small group members who are involved in legal cases for counsel. The counselor 
will be either a pastor or a Christian professional counselor to counsel new members. The counselor's remuneration will be borne by the counseled. Members who need counseling of any kind will go to the counselor for advice. This will help new members who are in trouble to find help in the church.

To assimilate new small group members in the church, some of the Adventist businessmen will hire new members who have lost their employment because of Sabbath problems or have been fired from their employment by non-Adventist bosses because of joining the Adventist Church. This move will enable new members who have lost their employment to solve their economic problems resulting from the change of denomination. Both men and women will be relieved from financial crisis that could have befallen them. For example, members who were working for companies that open their businesses on the Sabbath day.

Encourage older church members of small groups to fellowship with new members. This will enable members to build close relationships with each other. "We are saved in an isolated and individualistic Fashion. Salvation brings us into close relationship with each.other." ${ }^{, 12}$

Fellowship in small groups is vital, for "small groups within the church exist for members 'mutual' edification and fellowship."13 Fellowship in small groups develops intimacy with Christ and with one another. "In the early church, fellowship was more relational than recreational. It included sharing (1 John 1:7) and breaking bread

${ }^{12}$ Mallison, 9.

${ }^{13}$ McBride, How To Lead Small Groups, 33. 
(Acts 2:42) with other believers, as well as developing intimacy with Christ (1 Cor 1:9) and with other believers (Gal 2:9)."14

\section{Developing Small Groups for Spiritual Nurture}

Spiritual nurturing is "the process of growing in Christlikeness." 15 The goal of the church is to nurture "new Christians to become more like Christ." ${ }^{\text {"16 }}$ Small groups will be used to spiritually nurture new members so that they can "become more like Christ"17 The established members in churches will be encouraged to love and spiritually feed new small group members (John 21:15, 17). The small group members will be nurtured in spiritual formation and lifestyle.

Nurturing. The nurturing small group will function (1) to provide opportunity for new believers to make friends with other Christians and feel part of the congregation, (2) to identify gifts and interests as quickly as possible and help them find a role in the life of the church, (3) to ensure that spiritual foundations are properly laid (it takes more than one sermon or Bible study for a new Christian to understand what salvation is all about and develop a genuine sense of assurance in his experience with Christ), (4) to encourage

${ }^{14}$ Doug Fields, Purpose Driven Youth Ministry: 9 Essential Foundations for Healthy Growth (Grand Rapids, MI: Zondervan Publishing House, 1998), 138.

${ }^{15}$ Ibid.

${ }^{16}$ General Conference of Seventh-day Adventists, Discipling New Members (Silver Spring, MD: Department of Women's Ministries, 2005), 2.

${ }^{17} \mathrm{Cox}, 47$. 
daily personal Bible study and prayer, (5) to develop confidence in beginning to pray with other Christians, and (6) to enable group members to begin to share their faith."18

New members in the churches will need a lot of help and watch care. Each one of the local churches will have a nurturing small group or groups whose goal will be to retain new members in the church. It is always said that "the new born in Christ needs help, nurture, and watchful care. If there is any surprise, it should be that such care has not always been provided. New believers in our day have been too often over-looked and neglected." ${ }^{\prime 9}$ To help retain new members in the church, "Care should be exercised to educate young converts. They are not to be left to themselves, to be led astray by false presentations. Let the watchmen be constantly on guard, lest souls shall be beguiled by soft words and fair speech and sophistry. Teach faithfully all that Christ has commanded. Everyone who receives Christ is to be trained to act some part in the great work to be accomplished in our world."20

New members will be nurtured to live to please God. The pastors, elders, and small group leaders in churches will nurture new members in the church, instructing and teaching them how to live to please God. When small group leaders and the church provide "this kind of nurture and care will not only hold new members in the church, but

${ }^{18} \mathrm{Cox}, 47$.

${ }^{19}$ Caslow, 22.

${ }^{20}$ Ellen G. White, Evangelism (Washington, DC: Review \& Herald, 1946), 367. 
it will also produce stalwart Christians. We must help new members from the first steps after baptism to a role of becoming fruitful workers for God."21

Each church in the North Zambia Field will have a "nurturing small group." This small group will be used to nurture new members in churches. The nurturing in small groups will familiarize, orient, and bond new members to established members. Each of the nurturing small groups will have three to twelve members. Churches will encourage new members to join "nurture small groups" in local churches before joining other small groups in the church. A nurture small group is a special kind of small group for new Christians, where more emphasis is given to nurture than in other groups.

New small group members will be nurtured to take up the responsibility God has given to individuals and the church. The small groups and the churches members in the North Zambia Field have their own part to play in the nurturing of new members in the churches. Small groups and churches should look after new members. "God requires His church to nurse those who are young in faith and experience.",22

New small group members will be in a special class supervised by the pastor for one full year to fully nurture them. It is recommended that "one full year of nurture will be provided for the new member class which will be conducted by a new member ministry team selected by the pastor in counsel with the church board. The pastor's role

$$
\begin{aligned}
& { }^{21} \text { Ibid., } 23 . \\
& { }^{22} \text { Ibid., } 353 .
\end{aligned}
$$


is to supervise and monitor the program. The ministry team leader will function as the teacher and instructor of the new member's class." 23

Spiritual Formation. Small group members will be taught how to pray always without ceasing. Prayer is the key to open the windows of heaven. Small groups will encourage new members to talk to God three times or more a day. They will learn to commune with Him daily in prayer. Small group members will be encouraged to pray so that they can be filled with the Holy Spirit who will empower them in His service and help them to become more like Christ.

The small group members in the churches will "consecrate"24 themselves to God in prayer every day in the morning. Leaders of small groups will instruct small group members in the purpose and various aspects of prayer. For example, new members will be instructed on how to talk to God in prayer, studying different kinds of prayers and requests, positions in prayer, private and public prayers. Practical small groups will learn that God answers prayers. For example, God answered Elijah's prayer (1 Kgs 17:21; 18:36-39). Small group leaders and mentors will teach new members how to pray for themselves, their families, neighbors, unbelievers, enemies, and spreading of the Gospel world wide.

New small group members learn how to study the Bible as the Word of God. Small group leaders will encourage new members to study the Word of God always

${ }^{23}$ Caslow, 20. 48.

${ }^{24}$ Ellen G. White, Steps to Christ (Mountain View, CA: Pacific Press, 1948), 43- 
(2 Tim $2: 15 ; 3: 13-17)$. They will learn to study it deeply alone, with their spouses, and with their children to facilitate a better understanding of the things of God. They will strive to make it "the rule of faith and doctrines." 25 Small groups will teach members the purpose of the word of God, to believe in the promises, and the power of the Word of God. The leaders will instill in the minds of new members that the Bible is the inspired Word of God (2 Tim 3:16). The new small group members will be nurtured and guided to understand and to believe by faith that the Bible "is the power of God for the salvation of anyone who believes" (Rom 1:16).

The new members of small groups will be nurtured to strengthen their faith. It is expected that when people in small groups in churches have been fully nurtured and have matured, positive results will be seen in their change in character. For example, when Dale Galloway's church was fully nurtured it's membership grew to over five thousand. Pastor Dale Galloway, the pastor of America's largest small group church (which grew from a single small group in his home to a membership of over 5,000 in less than twentyfive years), came to the following conclusion, "I believe that people grow at least eight times faster when they're in a small group and attending weekly worship services ... than if they just attended the service itself."26

New members in small groups will be instructed in the truth of the day and strengthened in their walk with Jesus. "There is one great impression found in the New Testament by the apostles. They spent much time instructing and strengthening the early

\footnotetext{
${ }^{25}$ White, Gospel Workers, 249.

${ }^{26} \mathrm{Cox}, 46$.
} 
apostolic Christians. Paul went out again and again to strengthen new Christians. Text after text tells how the apostles encouraged the new converts to live a life worthy of the Lord $(\mathrm{Col} 1: 9,10)$, and strengthening them with the truth of the day and to remain true to their faith (Acts 14:21, 22)."27

Lifestyle. New small group members will be taught new Christian lifestyle in their spiritual growth so they can become like Christ. The church leaders in the North Zambia Field will nurture new small group members to become like Christ in their daily personal relationship with Christ by closer communion with God, allowing the Holy Spirit to work in their lives, and by keeping the Law of God and upholding the standards of the church. For example, new members will grow in their daily personal relationship by daily doing what the Bible teaches. Practical small groups will teach new members to strive to live selfless lives in the community, to let God take care of their lives and to help them live lives of "wholly consecrated to God," Christians. ${ }^{29}$ This will enable them to grow spiritually.

Small group members will practice and live the health message to help them care for their body, which is the temple of God (1 Tim 6:9-20). Pastors and elders will caution new members to use their talents and gifts for the glory of God (1 Cor 13). These instructions and lessons to new members will continue so that they may grow to become

${ }^{27}$ Caslow, 22.

${ }^{28}$ Ellen G. White, Desire of Ages (Mountain View, CA: Pacific Press Publishing Association, 1940), 251. 470.

${ }^{29}$ Ellen G. White, Ministry of Healing (Mountain View, CA: Pacific Press, 1948), 
mature Christians (Eph 4:12,13). The new small group members will learn about eight natural remedies: pure water, air, eating the right food, trust in God, exercise, cleanliness, sunshine, and enough sleep. ${ }^{30}$

Outreach. Small group members will learn how to witness to their own family members and to the people in their community. The leaders and mentors will teach them how to give testimonies to their own family members and their neighbors. God will send them out into the world as "a letter to the family, the villager, the street."

Worship. The newly baptized members in small groups will be taught how to worship in small groups. They will follow McBride's suggested guidelines for small group leaders in planning their worship activities. This means that worship activities in groups will be planned, as model, creative, comfortable, contextual that is, influenced by surroundings, and contents will be biblical. ${ }^{32}$

\section{Developing Small Groups for Service}

Service is defined this way, "the verb to minister means "to serve," "to give help." ${ }^{, 33}$ Small groups in the North Zambia Field will provide service to those in need in various ways and forms. Small groups will follow Christ's example of serving others in

${ }^{30}$ General Conference, Discipling New Members, 4.

${ }^{31}$ White, Steps to Christ, 115.

${ }^{32}$ McBride, How to Lead Small Groups, 89.

${ }^{33}$ Donald Venes, Taber's Cyclopedic Medical Dictionary (Philadelphia: F. A. Davis Company, 1997), 1876. 
His ministry. The Bible tells us, "For even the Son of man came not to be ministered unto but to minister, and to give His life as a ransom for many (Mark 10:45). While serving others, "each one should use whatever gift he has received to serve others, faithfully administering God's grace in its various forms (1 Peter 4:10). Jesus Christ calls upon Christians to serve those in need. For example, Jesus calls upon Christians to serve people who are hungry, thirsty, sick, strangers, and naked (those who are not properly dressed) (Matt 25:45). Small groups will draw their own program to incorporate Christ's example in His service to the needy. Small group leaders will organize members in their small groups for service according to each member's God-given talents and gifts.

Various lists of Christian service are identified in the Bible and other specific forms have developed in the Zambia context. The following is a list of service currently recognized as important in Zambia: aid to the poor, help to widows and orphans, ministry to the family of the deceased, the sick, poorly dressed, new members and visitors, falsely accused, abandoned runaway kids, seniors, elderly, refugees, unemployed, disaster victims, disabled, etc. This model describes how small groups can be used to motivate, educate, and organize new members for the other forms of Christian service. Details cannot be provided here of how each service will be provided because the focus is on development of small groups. Several steps will be taken to guide small groups in a local church into service.

First, the needs of the people in the church and community will be identified. According to the Zambian situation, the following people have been identified as having needs that require the services of small groups in churches: the poor, widows and 
widowers, patients or the sick, prisoners, poorly dressed, strangers or visitors, those falsely accused of witchcraft, runaways or abandoned children, seniors, refugees, unemployed, disaster victims, disabled, and those who are hurting.

Second, small group committee/leaders will identify various people that need the different services of small groups. They will also study the gifts of all the members of the small groups. Then they will match the people with their gifts and the peoples' needs in order to provide the service required.

Third, when needs and resources are identified, each small group will be led to decide which service it can provide. Small group leaders/committee of the groups will now study the ability of the small group to be able to provide the service required. Then they will assign the service to each group. In the churches, the following are the proposed assignment of small groups to people, and the services.

The special small groups will serve the poor members in church. Small group leaders of churches will identify different needs of different poor people in small groups. The small group members will cater to poor members according to their needs. The poor people are defined as those who lack the basic things of life, i.e., enough food, clothes, blankets, and running water in their homes. Their house may be collapsing because of lack of money to buy material to fix the roof or the walls. The small groups in the North Zambia Field will identify the poor new members in each group and assess what each family is lacking. The leaders of small groups will seek for people in the small group or church who have more than they need to donate to the poor families some food, clothes, blankets, materials for fixing their houses, etc. 
Widows and widowers in small groups are defined as people in need when they have no other relationship. The special small group members will provide service to widows and widowers in small groups according to their need. The widows' and widowers' needs range from comfort; food; clothes; shelter; prayers, visits from pastors, elders, and church members; babysitting, etc. The churches will identify the needs of widows and widowers and encourage members who are best qualified to provide the services they require. For example, new members who have lost their spouse need comfort. They will need Christian counselors, other people from the church to comfort them during the funeral and after the funeral. For example, the spouse may need food for the family because of the passing away of one of the spouse who was the bread winner.

The small group leaders will assign group members to provide food to the family of the deceased. If the spouse lacks clothing, the small group will seek for donations of clothing from the church and other relevant organizations. If the spouse lacks shelter, the small group leaders or the church will find some other alternative accommodation for the family. Where the new member needs a special visit and prayers from the pastor, elders, and members of the church, the small group leaders will make arrangements. If the widower needs the service of a babysitter, the small group leaders will look for one and make arrangements for volunteers in the small group or church to provide the requested service.

The new members of small groups who are sick in hospitals at Mpika, Mbala, Mansa, Kasama, Mpulungu, Isoka, or other health centers in the North Zambia Field are people in need. The special small group leaders and members will provide the needs of 
new members who are hospitalized. Some of the needs of the sick new members are pastoral visits, prayers, medicine, transport, money, et cetera. ${ }^{34}$ The small group leaders will make arrangements for the small group members to visit those who are ill. Leaders will also make arrangements, where possible, for the pastor, elders, deacons, deaconesses to visit and pray with the new members. If the sick member cannot afford to pay for medical treatment at the hospital, the church will subsidize the cost of treatment. Where a sick member needs transportation from his or her home to the hospital, the small group leader and the church leaders can make arrangements for the patient to be transported to the hospital or clinic. If the new member needs money to pay for either cost of treatment or transportation, the leaders of the church will call for donations to raise the money for the patient.

The members of small groups in prisons are people in need. The special small group leaders will provide service to new members who are incarcerated at Nchelenge, Mansa, Kawambwa, Kasama, Isoka, Mbala, and Mpika prisons in the North Zambia Field. Some of the needs of the prisoners are visits from family and church members, papers, envelopes, stamps, soap, food prepared by spouse or family members, etc. ${ }^{35}$ The small group and church leaders will arrange for the pastor and church members to visit new church members who are in the prisons to pray with them and to study the Bible.

${ }^{34}$ Pastor Bright Mwenya, the former departmental director in charge of community services of the North Zambia Field 2003-2006, provided for the needs of those in hospitals, the poor needy new members, and prisoners in prisons. Telephone interview, July 26, 2006.

\footnotetext{
${ }^{35}$ Ibid.
} 
The small group leaders in the North Zambia Field will encourage the family members to visit their relatives in the prisons. During the visit of the pastor and the church members to the prison, they will take paper, envelopes, stamps, soap, and food to give to the prisoners.

The poorly dressed new members in towns and villages in the North Zambia Field are people in need. The special small group and church members will provide clothes for new members of their small groups. The needs of the new members will most likely include shirts, shorts, pants, dresses, shoes, jackets sweaters, socks, blankets, sheets, pillows, mattresses, etc. ${ }^{36}$ The small group leaders will identify the specific needs of new members and their sizes. The leaders will seek donations of clothing from members and various organizations. When the clothes are collected, the poor will be called to come and receive them at the church or in the church hall.

The visiting new members from other churches and other visitors are strangers that are in need. The new member visiting the town or village church should be welcomed by the North Zambia Field churches. Some of the stranger's needs may include lodging for a night, hotel, motel, eating place, a meal, a friend, entertainment, care, etc. ${ }^{37}$ The small group member assigned to welcome strangers will provide them with lodging, a meal, and other necessities. The small group and church leaders will assist the member in providing the service to the needy strangers. Strangers who are new members and are able to pay for services on their own but need direction to the hotel for

\footnotetext{
${ }^{36}$ Mwenya.

${ }^{37}$ Ibid.
} 
lodging and upkeep will be guided by any small group member or church member. The pastor and local church leaders in the North Zambia Field, will provide other services to strangers that visit the churches unexpectedly.

The new members in churches in villages of the North Zambia Field falsely accused of witchcraft are people in need. Some new members experience problems in village churches in rural areas where witchcraft is practiced. Some of their needs are a shelter away from the village, protection from accusers, church guidance, etc. ${ }^{38}$ The special small group leaders, church leaders, and church members will provide a shelter away from the accusers. These leaders and members will protect the accused from accusers. They may counsel with him or her and guide him or her in this matter. After counseling and praying they will advise him or her to reconcile with the people in his or her village.

The abandoned, runaways, and street kids in towns in the North Zambia Field are people in need. The traditional communal system for caring for the abandoned, runaways, and other kids in villages is not practicable in towns where this system has broken down. Some of the new members have children who run away from home. Parents whose children have preferred to go and live on the street in Mansa, Kasama, Kawambwa, Mpika, Nchelenge, Isoka, Mbala, or Mpulungu are in need. Some of the

${ }^{38}$ The needs of people accused falsely as witches was obtained from a church member at Chimpempe Seventh-day Adventist Church, where the latest incident happened. The interviewee sought for anonymity for security reasons. The interview was on August 6, 2006. 
new members from the towns have abandoned their children before accepting Christ as their personal Savior.

These new small group members who have abandoned their children need help. Some new members abandoned their children because they were involved in some crime activity or some bad behavior which brought shame on their parents. Some of the needs of the new members in this category include the following: how to reconcile with their children, counseling, bringing their children home, police beat patrols, food and clothes for children, etc. ${ }^{39}$ The new members whose children are on the street and the children on the streets need to be reconciled to their parents. The parents need the church members to help them bring their children home. The children need their food, clothing, and their parents. The small group and church leaders in the North Zambia Field need to establish and identify ways of bringing these two parties together. They need to plan to involve the police on the beat patrols on the street and engage counselors for parents and children.

The seniors in towns and villages in the North Zambia Field are people in need. These seniors are not kept in old people's homes like in Western countries. Most of them are kept in homes of their relatives or family members. Some of them are on their own. For example, there are those whose relatives have died in an epidemic like HIV/AIDS, malaria, and smallpox, or poisoned. Others have lost their family members in traffic accidents, fire, drowning in the lake or river, in a mine disaster, etc. Some of the new members are elderly people who have lost relatives in an epidemic or in a disaster. These people need help in any form. Some of the needs of the old people in the villages include

${ }^{39}$ Mwenya. 
fixing the wooden doors, sweeping the rooms of their house, cooking, drawing water for them, collecting fire wood, providing new winter coats, etc. ${ }^{40}$ The special small group and the church leaders will identify the old people in villages that need their services and look for volunteers in the church and other organizations to provide the service and clothes needed.

The senior or elderly people in towns need money to buy food, pay for electricity bills, rent, laundry, new winter coats, etc. These elderly people need all the help they can get from the small group or the church. The special small group and church leaders will look for sponsors to support these old people in the church. The sponsor or the church will attend to the needs of the old people. Fortunately for the church, there are very few old people who need all the services because most of them are on government or mining company pensions. The remunerations from the government or mining company takes care of most of their needs.

The refugees in camps are people in need. Some refugees from the war torn Democratic Republic of Congo join the Seventh-day Adventist Church in the North Zambia Field. The refugees attend an evangelist effort conducted by a pastor or layman at any of the refugee camps along the Luapula River and on the shores of Lake Mweru. The refugee camps are run and organized by the United Nations and the government of Zambia. Some of the refugees' needs include church services, prayers for their families

\section{${ }^{40}$ Ibid.}


in Congo, Bibles, hymnals, Sabbath school study guides, etc. ${ }^{41}$ Most of their food, clothing, and medicines are provided for by the United Nations and the government of Zambia. The church provides church services by appointing leaders from the church to conduct church meetings on the Sabbath day. The small groups will provide Bibles, hymnals, study guides, and prayer for their family members left in the Congo. If refugees have more needs than what the local church can offer, the local church will contact the Adventist Development and Relief Agency (ADRA) at the field headquarters in Mansa. For example, if the refugees need shelter, clothes, more food, seeds, farm implements, other religious books, etc. ${ }^{42}$

The unemployed new members in the Seventh-day Adventist Church in the North Zambia Field churches are people in need. Some of the new members are unemployed because they were dismissed as a result of Sabbath observance. Others are unemployed because they are not educated or trained for jobs on the market. Some of the new members who are unemployed are those that are in high schools (secondary school). Some unemployed new members are those who are beyond the employment age. Other unemployed new members are fishermen on Mweru, Bangweulu, and Tanganyika Lakes who are observing a fish ban by the government to allow fish to breed. Some of the new members are unemployed as a result of exploiting the allocated land for their sawmills.

${ }^{41}$ Isaac Kaputo, secretary-treasurer in the North Zambia Field from 2004-2007, provided information on the needs of the refugees in camps in a telephone interview on May 26, 2006. He is the ADRA director for the field.

${ }^{42}$ Ibid. 
The needs of the unemployed new members include food supply, jobs, training, cooperatives, new allocation of land, seasonal employment, etc. ${ }^{43}$ The affinity/ evangelistic small group leaders will seek for Adventist men and women owning different businesses to provide jobs for new members. Otherwise, the church can encourage members to open young farmers clubs or cooperatives for unemployed members. The small group members in Mweru, Bangweulu, and Tanganyika Lakes can be engaged in doing something else as they await for revocation of the fish ban. The carpenters who have exhausted their allocated land can do something else and apply for new allocation of land.

The new members who have experienced disaster such as fire, floods, war, drought, theft, and poor harvest are people in need. New members who experience fire are mostly those living in grass-thatched houses in villages in the North Zambia Field. New members living along the lakes, Luapula River, and other big rivers sometimes also experience floods. Farmers in the North Zambia Field sometimes experience drought and poor harvests because of the lack of rain. Some of the new members in churches in the North Zambia Field lose their personal belongings by theft in towns. These new members need food, clothes, seeds, shelter, etc. The small group and church leaders will work with the government agencies, community services, ADRA, and individuals to provide food, clothing, and other supplies to alleviate the suffering of victims of disaster.

${ }^{43}$ Pastor Mufunda, district local pastor for Samfya Mission in the North Zambia Field, provided information on carpenters needing new land leases for their sawmills in Samfya district, May 11, 2006. 
The new members who are disabled are people in need. The new members who are disabled in the North Zambia Field include the blind people, those who have lost their limbs in auto accidents, war, mines, farms, fishermen attacked by crocodiles and hippos, due to different kinds of illnesses, those born with other body defects, etc. ${ }^{44}$ Their needs include wheelchairs, education, training, medication, treatment at hospitals, artificial limbs, campaign against the evils of war, etc. Where possible, the small group leaders will contact the various organizations or government to compensate war veterans, and the mining companies to do the same. The special small groups and ADRA will attend to some of the needs of the disabled people in the North Zambia Field.

Some of the new members in the North Zambia Field are in need because they are hurting. New members hurt because of loss of a spouse, sickness, living in poverty, hunger, idleness, inactivity, unnecessary worries; loss of money by theft, etc. The leaders of various types of small groups will identify the various needs and seek for donations to help those hurting. Some of the needs will be attended to there on site, such as need for counseling for loss of the spouse, inactivity, unnecessary worries, prayers, food, medical attention, clothes, etc. Other needs will be attended to as funds are available.

The new members in small groups will be trained to give first aid in emergencies. The mentors and small group leaders will invite government medical officers and licenced church members to coach new members in the giving of first aid in emergencies. For example, fire, which is common among those who live in the villages in the North Zambia Field.

${ }^{44}$ Mwenya. 
In order for provision of service to those that need it to succeed in the church and the community, both old and new members in small groups will make a commitment to work for God in the church and to teach other new members that God requires their commitment to His work. Small group members will attend seminars in the church to prepare them to serve. They "are to be carefully instructed, that they may have an intelligent knowledge of the various lines of work committed to the church of Christ." ${ }^{\text {.45 }}$

\section{Developing Small Groups for Training in Discipleship}

A disciple is "a fully committed follower of Christ ... an apprentice learning from his teacher by observing and practice. And as part of our learning and growing experience, we are commissioned to encourage others to join us "46 $\mathrm{A}$ disciple is "an apprentice to Jesus. ${ }^{347}$ Discipleship includes "every area of a Christian life, every Christian discipline." ${ }^{48}$ It is "living as Christ would if He were in my place." ${ }^{.49}$ Several steps will be taken to prepare the members in churches for discipleship.

1. Training of the church members to prepare them will start with a revival meeting of one week long to be conducted by the pastors, and other professionals. See lesson notes in the appendix. The entire church will be involved in small group discipleship training. The North Zambia Field pastors will see that the churches in their

${ }^{45}$ White, Evangelism, 338.

${ }^{46} \operatorname{Cox}, 39$.

${ }^{47}$ Donahue, 24.

${ }^{48} \mathrm{Cox}, 39$.

${ }^{49}$ Donahue, 24. 
districts are involved in small groups. The churches will do all they can to see that the program of small groups in their churches succeeds. The elders and other church leaders will cooperate with the small group members and leaders in the church. They will work hand-in-hand to encourage those members who might not have joined any small group to do so. The leaders will see that members are trained in outreach programs of the church. It should be known that when small groups go out to make disciples, they are following the great commission given to the church by Jesus Christ in Matt 28:19, 20.

2. The pastors and committee will outline courses to be taken at revival meetings and seminars such as: outreach programs, marriage enrichment seminars, cooking, home management, community service, and public evangelism.

3. After small groups are organized and their leaders chosen there will be training of leaders of small groups, mentors, coaches, and new members to be conducted by pastors, departmental directors, and other professionals.

The pastors and professionals will train the small group leaders, mentors, and coaches. The pastor and church elders will arrange for training sessions for the small group leaders and coaches. The church leaders will arrange training of the leaders with the local church pastor, the district pastor, field, conference, Union and Division departmental directors. The pastor will see that the small group leaders have teaching aids for use in the seminar and in their group meetings such as, books, papers, sermon materials, textbooks, etc. The leaders of small groups will be trained to run small group meetings, leadership, management of small groups, how to conduct a lesson in a small group setting, lead a discussion, etc. 
Marriage enrichment and home management professionals in the church will train leaders of women in small groups in churches in marriage affairs and home management. They will be instructed on how to manage their own marriages and how to raise children. Instructors will train women in cooking and preparing healthy vegetarian meals for their families. The Dorcas Society small groups will involve women in community service activities, e.g., running of the Dorcas community fair. This is a yearly event held by Dorcas members to show their skills in cooking, knitting, and sewing to the members of the public. It is shown to the members of the public at their own church show grounds or at the district show grounds run by the government after asking for a stand to show their products to the public. Sometimes Dorcas Society members take prepared food to the homes of seniors. Members of the Dorcas Society will sweep and clean the homes of the elderly people in the villages and towns.

4. The small group members in churches will be looking for disciples from several sources, i.e., visitors, new converts, people from other churches, relatives, family members, and neighbors. When they join the churches, small group leaders and mentors will equip them to disciple others in their families, churches, and community. The new members will be trained in the school of evangelism at the local church. Mentors will train them to witness to family members, neighbors, and people in the community.

5. This small group model will seek to train new members in discipleship to be committed Christians who will encourage others to join them. In their small group new members will find God, there will be training, mentoring, guidance, and by example, small group members will become intern disciples. 
The new members in churches will learn discipleship from coaches, leaders, and mentors who are fellow members of their small groups. Mentoring "means training new members to let their light shine, so that they become the salt of the earth to others who do not know the love of Christ." ${ }^{50}$ It also means that "when souls are converted, set them to work at once." In fact, "no sooner does one come to Christ, than there is born in his heart a desire to make known to others what a precious friend he has found in Jesus,, The mentors in the North Zambia Field churches will "accept new members into the church family, encourage new believers, any time, any where, provide friendship and spiritual bonding, teach by example, and listen to questions. Mentors will offer Biblebased solutions, provide positive help in times of need, share from personal testimony, point new believers to Christ, prepare new believers for active service for the Lord and explain Seventh-day Adventist Church structure." 53

Small groups will organize evangelism geographically in their territory. In the North Zambia Field churches, small groups members' evangelistic activities will be organized geographically to enable everyone to participate. The small group leaders will "ask an artisan to make large maps of the territory about five by five feet and hang on the backside wall inside the church building where they can be seen. On one map, locate where each church member lives and from this establish each group by placing members

\footnotetext{
${ }^{50}$ General Conference, Discipling New Members, 7.

${ }^{51}$ White, Evangelism, 355.

${ }^{52}$ White, Steps to Christ, 78.

${ }^{53}$ General Conference, Discipling New Members, 7.
} 
together who live near each other. On the second map divide the territory for missionary work." 54

The small group leaders will assign each member missionary territory. Small group members will be assigned a territory of their own. In this territory, they will learn streets, house numbers, and names of the people who live there. It is this territory where they will witness door-to-door. Small group members will be missionaries in their territory. They will give Bible studies, visit the people, and study the Word of God with the people. When it is time to ask for decisions, small group members will make an appeal for a decision to accept Christ as their personal Savior and for baptism. The 1974 annual council voted "to adopt a plan for assigning each church member a specific missionary territory in harmony with the counsel of the Spirit of Prophecy. The Spirit of Prophecy offers abundant support for this plan."\$s

The small groups in churches will use the territorial assignment principle in their evangelistic activities. Small group leaders will see that the principle of territorial assignment is used to the maximum. It is easier for the members to invite people from their territory to attend an evangelistic effort. It is also easier to follow them up after they have made a decision. It has been observed that "most business organizations follow the 'territorial assignment' principle to reach their objectives. The strongest business firms

\footnotetext{
${ }^{54}$ Cerna, 55 .

${ }^{55}$ Ibid., 63.
} 
are the ones that have most faithfully followed this method. Why should we do any less, when we have something so much more important to offer to people." ${ }^{\$ 56}$

\section{Small Groups for Adjunct Pastoral Care}

Pastoral care involves "care giving and shepherding." 57 At the present time, there are sixteen pastors posed to provide pastoral care for 331 churches and 872 companies, and a total 90,245 members (February 2006)..$^{58}$ The North Zambia Field has a large volume of members and it has not become easy for sixteen pastors to serve so many church members. Small groups can have just potential as a multiplier of the pastor's efforts. This small group model proposes that small group members will function as "adjunct" or as assistant pastors in providing care to the members.

1. Small groups will effectively provide "adjunct" pastoral care in following situations to new members who are spiritually sick, bereaved families, senior or elderly people, those going through marital problems, those who are hurting, new members, new members who are scattered by offshoots, those who have lost their job because of Sabbath observance, unemployed, those who have experienced a disaster, those experiencing terminal disease, broken hearted, those going through divorce, etc.

${ }^{56}$ Cerna, 65.

${ }^{57}$ Donahue, 153. 2006.

${ }^{58}$ Isaac Kaputo, North Zambia Field Secretary's Statistical Report, January 10, 
2. Pastoral care will be provided by members of small groups who are gifted in different areas, such as: pastors, professionals, small group leaders, individuals members of the church, etc. These are the different types of care that they will provide.

Primary care "is the normal, regular attention and support that a small group leader is expected to provide for his or her members. Such care includes prayer support, phone calls, encouragement, visiting the sick, and finding resources that will meet the needs of the group members' care needs. ${ }^{959}$

Mutual care is "what group members give to one another.... This kind of care includes taking meals to families with new babies, visiting those in hospitals, and providing prayer and assistance with other needs (Gal 6:2). ${ }^{, 60}$ The small group members will provide backup care which is "the first line of defense is your coach. If your coach is unavailable, contact your division leader or other church leader."${ }^{.61}$

Crisis care giving in case of impending physical danger. It is advisable when such a situation arises to "contact the police immediately. Such crises covered include life threatening situations, severe accidents or emergencies, an attempted or threatened suicide, present threat of violence by a person to him or herself or to others.... It is very unlikely that you would ever experience any of these in a context of a small group
${ }^{59}$ Ibid.
${ }^{60}$ Ibid., 154.
${ }^{61} \mathrm{Ibid}$. 
meeting (or even with members of your group), but it is necessary to be aware of the possibility and know that you should contact the police immediately."62

Serious situations involving church members and members of the public. The church leaders will train the small group members in various ways of handling other serious situations arising in their vicinity or locality. Some of the other serious situations where a small group member or leader would need guidance to address include "child abuse, or neglect, spouse abuse, etc. Contact your coach or church immediately for help in discerning the severity of the crisis and for assistance in reporting the incident to the proper authority if needed. ${ }^{163}$

Support and counseling to new members in churches. However, it is a known fact that as a small group "you are expected to provide support and encouragement to members of the group. If you are not a trained professional counselor, you should not assume that role. Instead, your responsibility is to provide opportunity for your members to receive the appropriate care they require. Situations that may require professional help include serious marriage problems, history of abuse, addictions, severe personality disorders, mental disorders or dysfunctions." ${ }^{\prime 64}$ The small group leaders in the North Zambia Field will work hand in hand with professional Christian counselors, pastoral counselors, marriage therapists, traditional village marriage counselors, medical

\footnotetext{
${ }^{62}$ Ibid., 155.

${ }^{63}$ Ibid.

${ }^{64} \mathrm{Ibid}$.
} 
counselors, family members to give counsel to bereaved members of the family, school children, etc.

3. Pastors and professionals in the churches will train small group members in pastoral care. Pastoral care will include training new members in youth programs to equip them for service. The majority of church members are young people in schools, colleges, and universities. Pastors and professionals will train the young people in the small groups and the church to enable them to serve in the church and win others to Christ. White wrote, "Every soul united with Christ will be a living missionary to all around him." ${ }^{95}$

Pastors and professional counselors will provide physical and moral support, and counseling services to terminally ill new members in their small groups. The terminally ill members will expect the church leaders to pray for them, and church members to visit. The member who is ill needs church members to guide them spiritually to prepare for their death, burial, counsel them to make arrangements for donation of their wealth to the church and family, and make provisions for church ordinances, e.g., the Lord's Supper and anointing services. The local pastor, church leaders, counselors, and small group members will visit and pray with terminally ill new members to guide and provide counseling

They will provide pastoral care in terms of physical and moral support, and counseling services in towns and villages to abandoned and street kids in the North Zambia Field. The abandoned and street kids expect the pastors and church members to

${ }^{65}$ White, Evangelism, 319. 
help them reconcile with their parents or guardians. They want to be invited to church youth programs, asked to join the church school, provided with shelter, clothes, shoes, orphanages, etc. The small group leaders and church leaders will arrange for meetings of parents and abandoned children to reconcile them to each other. Small group leaders will seek for donations and funds to pay for shoes, clothes, and to build orphanages. They will look for sponsors to support some of the street kids and abandoned kids to enroll at schools in towns and villages. Education in Zambia is provided free by the government of the republic of Zambia. However, students are required to pay for their own school uniforms, stationary, and text books. Furthermore, the small group leaders will provide moral and physical support to the abandoned and street kids enrolled in school, they will sign in for the school to send quarterly progress reports.

4. The church leaders will provide pastoral care in the following ways:

Church briefing (open meeting). Small group leaders, coaches, and trainers will encourage church officers to keep new members well informed on the stand of the Seventh-day Adventist Church on matters concerning fornication, homosexuality, incest, sexual abuse, physical violence, Sabbath breaking, smoking, drinking alcoholic beverages, narcotics, drugs, coveting, fraud, etc. This will be held at lest once a year at the local church to remind the new members about new changes and church standards. New members in various small groups will be invited to attend. It will be held on a Sabbath afternoon so that even the old members who want to participate can attend the general briefing of the church 
Libraries. Small group leaders, mentors and coaches will encourage churches in the North Zambia Field to open church libraries for new members. These church libraries will be stocked with Christian literature. This will encourage new members to study deeply and understand the Bible, the prophecies, and the plan of salvation. Some of the books or topics that new members can study in the library include, the conflict series, Testimonies for the Church, the Church Manual, history of the church, doctrines of the church, Sabbath and Sunday, etc. Some of the books for the church library can be donated by members, other donors, Christian individuals, or organizations.

Lasting relationships. Small group leaders in the North Zambia Field will encourage the building of lasting relationships between new members and old church members. This will mean that old members will be discouraged to continue behavioral acts that are repulsive to the new members, such as being jealous of new members, picking only highly educated new members for training, failing to address needs of new members in church meetings, Bible studies designed to benefit old members, acting as police officers who catch new converts in violation of the Ten Commandments and church standards, failure to provide mentors to new members, misplacement of new members in ministries, thus encouraging them to fail, family churches, lack of programs designed to benefit new members in the church, etc.

5. Small group leaders, mentors, coaches, and professionals, etc., will provide pastoral care in the following ways.

Visit new members of small groups once or twice a month to see how they are coping with new doctrines and new Christian friends in the community. Visitation of 
new members will strengthen them in their faith and encourage them to stay on, regardless of some problems they could be facing as a result of becoming Seventh-day Adventists.

Encourage new members to attend marriage enrichment seminar designed for new members in the church. This seminar will involve couples, those with marital problems, those dating, divorcees, single parents, etc. The small group leaders or church leaders will invite marriage counselors, medical officers, firemen, teachers for children, etc. This seminar will cover topics concerning marriage enrichment, health at home, how to deal with fire in the home, and how to raise children and Christian education.

Help seniors in towns to help them sort out problems with pension pay outs, food, tracing family members to look after them, shelter, transportation to the hospital, etc. Small group leaders and church leaders will provide pastoral care and moral support to seniors in towns, such as Kasama, Mansa, Kawambwa, Nchelenge, Luwingu, Mbala, Isoka, Mpulungu, Chisali, and Mporokoso. Moral support to seniors in towns will include, visitations, prayers, Bible studies, taking of the Lord's Supper to their homes, etc.

Counsel seniors. The churches in towns will ask Christian professional counselors on the pastoral team, or engage a professional counselor to service seniors. Churches in the villages will ask the Christian professional counselor on the pastoral team or ask the Christian village elders to counsel or advise the seniors who need the service.

Counsel divorced new members in small groups in churches in the North Zambia Field to morally and physically give support and provide counseling services. The new 
divorced members in small groups will require moral and physical support as they go through divorce, the sharing of assets, looking for new shelter, custody of children, looking for new employment, new schools for children, food, seeking for reconciling with the former spouse, etc. The small group leaders and church leaders will provide the opportunity for them to have access to a Christian professional counselor and other professional counselors engaged by the church for the purpose.

Provide for bereaved families of new members. The bereaved families in the villages will need care provided to them from the church in the following areas: comfort them, making burial arrangements of the dead, provision of food at the funeral, paying for the funeral expenses, mourning with them for the loss of their spouse their only bread winner, and caring for children during the funeral period. The small group and church leaders will provide the family with members of the church to give both physical and moral support, and to provide counseling services. For example, the pastor and Christian counselor from the church will provide burial services at the church and prayers for comforting the bereaved family. The church small group members will provide babysitting services for the care of the bereaved family children and babies.

Traditionally, in the North Zambia Field, members of the church are expected to attend deceased new member's funeral services without invitation from the family of the deceased. A failure to do so would jeopardize the relationship between the absent member of the church and the bereaved family.

Provide pastoral care, support, and counseling services to new members who are ex-prisoners in the small groups in the church. The former prisoners will need to rebuild 
their image in the community, rebuild their reputation, learn new skills, provide food and other basics for their families, get new employment, build new relationships with new friends, etc. The small group leaders will assist the former prisoners to successfully overcome obstacles in their way, with the help of the pastor, counselors in towns, and village elders, church pastor, and church members in the villages.

Visit families of missing persons. Sometimes a family experiences missing one, two, or more family members in the forest, in the village, or in the town. The entire family goes into a shock and needs guidance, counsel, sympathy, prayers, visitations from members of the small group or the church. The church leaders, relatives, people in the community, and the police will organize a search party to look for the missing persons. While some people will be searching for the missing persons, church leaders and small group leaders will ask others to be with the family members at home to guide, counsel, sympathize and to pray for the missing persons to be found. The search party and members of the church will remain with the family until missing persons are found alive or dead.

6. Members of small groups will provide pastoral care in the following ways:

Providing care to new senior members in small groups in terms of physical and moral support. Seniors in the villages will need support in terms of food, clothing, drawing water from the river or well, smearing the floor, medical attention, Bible studies, prayers, thatching of roofs, preparing the gardens, etc. The small group leaders and church members will provide pastoral care to new senior members in terms of moral 
support such as prayers, Bible studies, taking the Lord's Supper to the homes of the seniors. The sick seniors will be transported to the nearest clinic.

Providing pastoral care to those small group members falsely accused of being a witch in the village. The falsely accused new member will require pastoral care in form of physical, spiritual, and moral support, and counseling services. For example, the falsely accused which will require temporary shelter, assistance to move to some other village, food, etc., for his or her physical support. Further, he or she will require prayers, visitations from church members, assistance to rebuild his or her reputation in the church and community, and counseling services from the Christian counselor, the local church pastor, and the church members. The small group leaders and the church leaders will assist the new member as they attempt to normalize relations with relatives and affected villagers in the village.

There are several benefits of small groups providing adjunct pastoral care to new members of the church. For example, some benefits of small groups providing care are as follows:

1. Fewer people will leave the church. Those "who leave the church by the back door-especially the young-are not necessarily turning their backs on God. What we call apostasy is more likely to be a matter of people failing to find encouragement and support when they are going through a crisis. If they find the support they need they will stay."

2. Pastors will be able to specialize. The second point is that when the pastor involves small groups in caring for newly baptized members, he will be able to specialize.

$$
{ }^{66} \mathrm{Cox}, 46 .
$$


The biblical role of a pastor is "that of teacher/trainer, preparing God's people for works of service, so that the body of Christ may be built up" (Eph 4:11). Pastors of small group churches will naturally continue to be involved in a certain amount of pastoral care, but they will be able to give priority to developing the gifts and skills which the Holy Spirit has given to the members of the church. The result will be congregations functioning just as Scripture says they should as a body with every part doing what it is supposed to do."167

3. Inclusion, support, empowerment, and accountability needs will be met. Finally, when small groups are involved in caring for newly baptized members in the North Zambia Field, it is possible that they will be able to meet some of the needs in the community. "Small groups will not meet all the needs. But they can address some of the most significant needs that humans possess, including biblically based needs for inclusion, support, empowerment, and accountability.".68

\section{Conclusion}

This chapter discussed how the North Zambia Field of the Seventh-day Adventist Church could become a model for mission to other fields and conferences in Zambia by forming small groups for assimilation, spiritual nurture, servicing those in need, training in discipleship, and providing pastoral care. Chapter six will now summarize, conclude, and make recommendations for action by the churches in the North Zambia Field.

${ }^{67} \mathrm{Ibid}$.

${ }^{68}$ Arnold, Big Book on Small Groups, 106. 


\section{CHAPTER 6}

\section{SUMMARY, CONCLUSION, AND RECOMMENDATIONS}

This chapter presents the summary, conclusion, and recommendations. The North Zambia Field needs to revamp their membership retention strategies. The task of this dissertation was to define the problem, engage in research, and prepare a strategy using small groups. The research revealed that new members left the church because they were not assimilated, spiritual nurtured, trained for discipleship, and there was a lack of pastoral care.

\section{Summary}

Chapter 2 discussed theological foundations of small group ministry based on the Old Testament, New Testament, the writings of Ellen G. White, and the general literature. The Old Testament theological foundations of small group ministry rests on the Triune God. God is a small group who is three Persons in one, a small group who is one (Gen 1:1); Israelites were a small group of chosen people of God (Deut 7:7-9); and the tribes in Israel were small groups (Gen 49).

The New Testament presents Jesus as using small groups and providing a model of their use in the church. In Acts and the Epistles small groups are found in general 
usage. The writings of Ellen G. White and the general literature on small groups builds on the biblical model.

Chapter 3 briefly discussed the theoretical foundations of small groups in psychology, sociology, anthropology, and education. These disciplines provide strong theoretical support for small groups in the church.

Chapter 4 discussed evangelistic growth patterns in the North Zambia Field, starting with a brief history of the people, missionaries, and the methods used in evangelism. The chapter also gave some of the reasons why new members either stayed in the church or dropped out in the 1996 to 2006 period.

Chapter 5 proposed a model for using small groups as a tool for enhancing member retention in the North Zambia Field. The following aspects were presented: new member retention, assimilation, spiritual nurture, serving members in need, training new members for discipleship, and providing pastoral care.

\section{Conclusion}

Through stewardship of its members, the church has money to conduct evangelistic meetings. In the North Zambia Field the many expenses associated with evangelism add up to about $\$ 200.00^{1}$ for each person baptized. In purely monetary terms, the Lord's money is wasted when people drop out. Yet, great concern is with the spiritual destiny of those who drop out. Many who drop out become immunized against future evangelism. Therefore, the church has a serious obligation to use the very best possible

'Author's personal estimate. 
methods to retain converts. The author is deeply committed to the small group model for member retention presented in this dissertation. By God's grace he believes that new members' assimilation, discipleship training, service, and pastoral care will be achieved in the North Zambia Field.

\section{Recommendations}

Following are recommendations to the North Zambia Field on new member retention at the Field, district, and church levels.

1. That North Zambia Field will provide training of district pastors and local church small group leaders involving trainers from the Southern African Indian Ocean Division, Zambia Union, and North Zambia Field at least once a year, and that at this meeting the Field Committee will discuss and vote on a one-year master plan with strategies on how to retain new members.

2. That North Zambia Field churches will use the following as textbooks for training and study.

a. 27 Fundamental Beliefs of the Seventh-day Adventist Church

b. Spirit of Prophecy books by Ellen G. White

c. Bible Readings for the Home

d. Marriage and Counseling by Nancy Van Pelt

e. Spiritual Body Building Lessons by Kim A. Johnson

f. The Great Characters of the Bible by Dr. Allen B. Stringfellow 
g. The Bible or any Bible designed for use by small groups

h. Any other books for small groups

3. That North Zambia Field will set up a day at the beginning of the year to launch small groups in its territory.

4. That in the North Zambia Field small group ministries will fall under the Lay Activities, Sabbath School departments, or the Ministerial Secretary's office.

\section{Recommendations for North Zambia Field Districts}

1. That districts in North Zambia Field will see that local churches in their territory arrange to have a meeting chaired by the pastor to discuss and vote a one-year master plan, mission statement, and formation of pilot small groups.

2. That districts in North Zambia Field will see that their churches organize different types of small groups according to the needs of newly baptized members.

\section{Recommendations for Churches}

1. That small group leaders in churches will see that in their local churches anyone charged with the training of small groups, like leaders, coaches, and professionals, have suitable books and training materials to be provided by the Field, conference, or other.

2. That small group leaders will see that the local church pastor or district pastor, elders, and small group members encourage newly baptized members to voluntarily join the Fundamental Beliefs Small Group, and see that they are provided with a Bible, 
hymnal, 27 Fundamental Beliefs of the Seventh-day Adventist Church, and other Spirit of Prophecy books, as needed.

3. That small group leaders encourage local church leaders to form Orientation Small Groups to orient all new members about the Seventh-day Adventist Church.

4. That small group leaders in churches will see that small group members are trained practically on how to pray, witness for Christ, conduct a Bible study, and how to discover or identify their spiritual gift or gifts.

5. That small group leaders involved their small group members in community projects at least once per quarter.

The researcher believes that the implementation of this small group model in the North Zambia Field will lead to greater obedience to the Great Commission to glorify God (Matt 28:20-30). And thus the researcher foresees a strong North Zambia Field with vibrant membership growth of both young and old coming from both Luapula and Northern Provinces of Zambia. The researcher is also convinced that these members will contribute their tithes and offerings to support the church and will also participate in evangelistic activities of the local church. In this way they will contribute more effectively to the numerical and spiritual growth of the church members, the fulfillment of the mission of the Seventh-day Adventist Church in the North Zambia Field, and to hastening of the coming of the Kingdom of God on earth. 
APPENDIX A

QUESTIONNAIRE 


\title{
APPENDIX A
}

\author{
QUESTIONNAIRE
}

\section{A. POSSIBLE REASONS WITHIN THE CHURCH FOR MEMBERSHIP LOSS}

What factors within the church program may explain why we lose members? Indicate the importance of the following reasons by circling the appropriate numbers.

1. Not a reason

2. Somewhat of a reason

3. A strong reason

1. Older members and church leaders are jealous of new converts who are potential leaders, and are willing to participate in any church programs. To guard their own positions in the church the established members hold new members back.

2. In church elections only highly educated converts are picked for training and equipping for service The middle class and lower class members, who make up the majority of converts, are left out of the training programs.

3. The needs of new converts are not adequately addressed in meetings and seminars designed especially for them. (For example: There are no separate programs for new converts with personal problems, smoking, drinking, etc.)

4. Bible studies conducted every Sabbath afternoon are focused on benefitting older members instead of the needs and spiritual growth of new members.

5. Older members and leaders of the church often fail to build long lasting relationships with new members. 
6. Instead of acting in a redemptive way to help new converts grow in their faith and practice, older members, leaders and deacons act as police officers who catch new converts in violation of the Ten Commandments and Church standards.

7. New converts are not usually assigned to mature members who will mentor them.

8. New converts are usually not placed in appropriate ministries after their baptism based on their spiritual gifts.

9. Many of churches are "family churches," meaning that one or two families control and lead out in all phases of church programs, making it hard for new members to participate.

10. New converts do not receive adequate instructions before baptism.

11. Established church members are not adequately involved in evangelism programs that bring new converts into the church.

Other:

Mpulungu Mission District

1. During the crusades not enough lessons are covered.

2. No continuance of nurturing.

3. No fellowship between new and older members.

Mwense Mission District

1. There no visitations by leaders of new and old members.

2. Boring programs.

3. Christians only meet on Sabbath.

4. Youth drop out of church because of wrong choices in their marriages.

5. Orphans are not properly cared for because luck of orphanages.

6. Offshoots within the church, which leads to their removal of their names from church records.

Mweru Mission District

1. Spiritualism is so high so much that some members have made it a business. 
2. Some of the older members become stubborn and bring confusion and disorder in the church.

3. Offshoots within the church disturb worship services

Nchelenge Mission District

1. Youths' early marriages to unbelievers or members of other denominations cause them to leave the church.

2. Beliefs in cleansing of the surviving spouse, causes new converts to leave the church.

3. Baptizing members who are not grounded in doctrines of the church.

Kazembe Mission District

1. When membership of the church grows too large only old members are elected to church positions.

2. There are no programs for the newly baptized members in the churches.

3 . The talents of newly baptized are not identified early enough for them to participate fully in church activities.

Kawambwa Mission District.

1. The newly baptized need literature (the Bible, spirit of prophecy books, etc.).

Kalungwishi Mission District

1. Newly baptized members do not have literature (the Bible, SS Study guide, spirit of prophecy book, church manual, etc.).

Lwena Mission District

1. There are no books; SS study guides and other church literature from the North Zambia Field in the district.

2. The newly baptized members are not warmly welcome by older members in the churches.

\section{B. PERSONAL REASONS FOR MEMBERSHIP LOSS}

For what reasons do new members most commonly have their names removed from church records?

(a) Mark with " $x$ " reasons for which members in your churches have been removed from church membership.

1. Idolatry, worship of idols

2. B__ Blasphemy, taking the name of God in vain 

3. _ Profanity
4.___ Gambling
5. __ Violence in the family
6._Dishonoring of parents
7.___ Sabbath breaking
8. ___ Adultery (when at least one is married)
9. Fornication (between unmarried people)
10. Homosexual practice
11. Incest
12. Sexual abuse of children and vulnerable adults
13. —_ Remarriage on unbiblical grounds
14. Physical violence or murder
15. ___ Fraud or misrepresentation in business
16. Falsehood
17. Coveting
18. Envy
19. N__ Non-attendance of church
20. ___ Persistent refusal to recognize properly constituted church authority or to submit to the order and discipline of the church
21.__ Adhering to or taking part in a divisive or disloyal movement or organization
22. Disorderly conduct which brings reproach upon the church
22. __ The use, manufacture, or sale of narcotic drugs
23. The use, manufacture, or sale of tobacco
24. The use, manufacture, or sale of alcoholic beverages
25. __ Witchcraft or participation non-Christian traditional practices or beliefs

Other:

(b) Having indicated reasons for which members have been removed from membership in your churches, please indicate which 5 reasons are most common. Rank in ascending order from 1 to 5 the most common reasons. (Of the 5 most common ones you choose, 1 is least common and 5 is most common.)

1.___ Idolatry, worship of idols

2. B__ Blasphemy, taking the name of God in vain

3. Profanity

4. Gambling

5. Violence in the family

6.___ Dishonoring of parents

7.___ Sabbath breaking

8. Adultery (when at least one is married)

9.___ Fornication (between unmarried people) 
10.

11. Homosexual practice

12. Incest

13. Sexual abuse of children and vulnerable adults

14. Remarriage on unbiblical grounds

15. Physical violence or murder

16. Fraud or misrepresentation in business

17. Falsehood

18. Coveting

19. Envy

20. ___ Persistent refusal to recognize properly constituted church authority or to submit to the order and discipline of the church

21.

22. Adhering to or taking part in a divisive or disloyal movement or organization

22. Disorderly conduct which brings reproach upon the church

23. The use, manufacture, or sale of narcotic drugs

24. The use, manufacture, or sale of tobacco

25. The use, manufacture, or sale of alcoholic beverages Witchcraft or participation non-Christian traditional practices or beliefs

Other:

\section{RETENTION, ASSIMILATION AND DISCIPLING OF NEW CONVERTS}

What actions are commonly taken in your church to bring new converts into fellowship and ground them in the faith? Indicate the frequency with which the following actions are taken in your church by circling the appropriate number.

1. Not done

2. Done for some new converts

3. Done almost always for new converts

1. We welcome them warmly into the church after they are baptized $\quad \begin{array}{lll}1 & 2 & 3\end{array}$

2. We invite them to a welcome table for a special meal typically on the day of baptism with all the members, elders, and the pastor. $\begin{array}{llll}1 & 2 & 3\end{array}$

3. We give each a free Bible, hymn book and Sabbath School Study Guide

4. We assign an established member as mentor to each new convert $\begin{array}{lll}1 & 2 & 3\end{array}$

5. We arrange special classes taught by elders for new converts 
6. We find out each new convert's needs and attend to each of the needs as best we can

7. We arrange a special question and answer session conducted by elders or the pastor for groups of new converts

8. We provide individual counseling for new converts to address personal problems

9. We train and equip new converts in outreach programs

10. We conduct seminars to strengthen marriage and family

11. We provide diet, nutrition and cooking classes for women

12. We socialize with new converts. For example, new converts are invited by older members to have meals in their homes

13. We encourage Seventh-day Adventist business people to hire new members who have lost employment because of Sabbath problem

14. We encourage Seventh-day Adventist business people to hire new converts who are unemployed

$1 \quad 2 \cdot 3$

15. We invite new converts to join different kinds of clubs run by church members

$\begin{array}{lll}1 & 2 & 3\end{array}$

16. We encourage older members to build long lasting relationships with new converts

17. We invite new converts to join different types of small groups in the church

\section{NURTURING OF NEW CONVERTS}

What actions are commonly taken in your churches to provide spiritual nurture for new members? Indicate the frequency with which the following actions are taken in your churches by circling the appropriate number. 
1. Not done

2. Done for some new converts

3. Done almost always for new converts

1. We conduct Bible Studies for new converts covering topics of their choice

2. We offer stop-smoking programs for new converts who have trouble stopping

3. We provide marriage and family enrichment programs

$1 \quad 2 \quad 3$

4. We invite them to join prayer groups

$123 \quad 3$

5. Elders and deacons visit new converts regularly

123

6. We provide grief recovery counseling and support groups or those who have lost loved ones

7. We enroll the new converts in VOP

8. We have spiritual formation programs at camp meetings

123

9. We provide Adventist Youth training programs

$\begin{array}{lll}1 & 2 & 3\end{array}$

10. We train new converts how to give personal testimonies

123

11. We teach practical ways of how to live by Christian principles

$\begin{array}{lll}1 & 2 & 3\end{array}$

12. We provide training programs in public speaking

$1 \quad 2 \quad 3$

13. We have a simplified witnessing-for-Christ training program

$1 \quad 2 \quad 3$

14. We have church libraries that include Spirit of Prophecy books and other materials

\section{E. SMALL GROUPS IN YOUR CHURCHES}

Please answer the following questions by marking with " $\mathrm{x}$ ' in the spaces provided.

1. Do you have functioning small groups in your churches?
(1) Yes
(2) No
(3) Not sure 
2. Do you know what small groups are for?
(1)Yes
(2) No
(3) Not sure

3. Have you had basic training in small group ministry?
(1) Yes
(2) No
(3) Not sure

4. Which of the following small groups do you have in your churches? If you have them, please indicate the approximate number of each on the line provided:

a. Fellowship groups (for spiritual and social interaction)

b. Bible study groups

c. Outreach groups (continuous witnessing groups to non-Christians, nonmembers, or non-attending church members)

d. ___ Task/ministry groups (one-time groups for specific tasks)

e. Support groups (for individuals with special needs, usually short term).

f. ____ Prayer groups (focusing on prayer, although there is also Bible study and sharing)

g. ___ Covenant groups (groups that agree to meet for specific activities for specified times. e.g. Prayer groups meeting once-weekly for one year)

h. ___ House church groups (meets for Sabbath or other services in a home)

I. ___ Cell church groups (having the small group as the main component of church activities)

j. ___ Sabbath school action units (uses Sabbath School class as an existing small group)

5. Would you like to start small group's ministry in your churches?
(1) Yes
(2) No
(3) Not sure

6 . Would you like to learn more about small group's ministry?
(1) Yes
(2) No
(3) Not sure

7. Do you think your church members would be interested in small group's ministry?
(1) Yes
(2) No
(3) Not sure

8. Do you think that small group's ministry will help to retain new converts in your churches?
(1) Yes
(2) No
(3) Not sure

9. If small groups were introduced in your churches would you be interested in training members how to lead small groups?
(1) Yes
(2) No
(3) Not sure 
10. Have you ever had training sessions of small group ministries in your churches?
(1) Yes
(2) No
(3) Not sure

\section{F. DETAILS ABOUT YOUR DISTRICT}

1. Total Membership in 2006

2. Total Membership in 1995

3. Members up to age 35

4. Members over age 35

5. Churches

6. Companies

7. Branch Sabbath Schools 
APPENDIX B

SMALL GROUP LEADER'S JOB DESCRIPTION 


\section{APPENDIX B}

\section{SMALL GROUP LEADER'S JOB DESCRIPTION}

\section{Duties of the Small Group Leader}

There are some basic tasks for you when you take the responsibility of leading a small group.

1. Preparations. Before the meeting the leader should pray specifically for the people who are coming. Pray also for your self as a person and as a leader. Specific preparations must be made prior to each meeting.

Arrangements. What needs to be done to care for details such as location, seating, Bibles, temperature, food, child care, music materials, etc.?

Relationships. How will you help people to feel cared for and caring? What will you do to help people get to know each other and build positive relationships among the members of the group?

Study Topic or Task. What steps will you follow to accomplish the task or go through the study. You will want to make a list of questions you will use and estimate the time each will take. What are your goals for the praying time? What will be your prayer format? Who will pray?

Time. How much time is available and how will you divide it? Block out the time into major segments and jot down the activity to done in each segment. What is your "real" starting time? Your final closing time? How will you open and close each segment? Are you attempting to much? Too little? Do you want to ask other people to take responsibility for some segments?

2. Facilitator. During the group meeting the most important function of a leader is to ask questions. As group leader you are not the expert lecturer but the facilitator and discussions and sharing. Be sensitive to individual needs. Try to create a climate of openness and acceptance through affirmation and encouragement. You will direct the flow of discussion by making sure everyone has an opportunity to express their thoughts and feelings. Try to keep the discussion on the subject. Make sure everyone in the group can see each other by arranging the chairs in a circle and removing the empty chairs. The leader helps the group members to be personal by sensitively asking questions that enable them to share openly without feeling coerced, intimidated or put on the spot. You will also need to deal with the problem of those who talk to much. Help the group focus on solutions 
rather than only problems. Ask questions that help people be positive and affirmative about themselves and other group members.

3. Caring for individuals. Outside the group meeting the leader stays in touch with group members by phone. You are the lay pastor of the people in your group. Watch for those who seem to be hurting or have questions during the meeting. A prime time to offer care and support is during the informal conversation immediately following group meetings. Try to plan your time so you can stay by, but don't let troubled people consume your time and energy. Be free to say, "You seem to be hurting a lot. How can I assist you in getting help?"

4 Outreach. A healthy group always"keep an empty chair" for new people. One of the tasks of the leader is to likely group members, invite them to try the meetings, and help the group to make them feel comfortable and safe.

You should watch for visitors on Sabbaths, new comers in the community, individual going through lonely times in their lives and especially unchurched friends and acquaintances who seem to be opening up to spiritual things.'

'North American Division of the Seventh-day Adventist Church, Responsibilities in the Local Church (AdventSource, Lincoln, Nebraska, 2002), 38-39. 


\section{APPENDIX C}

SMALL GROUP LEADER'S MONTHLY REPORT

AND EVALUATION 
Leader's Name:

Date:

Number of Meeting This Month:

Day and Time of Group:

Location:

Type of Group:

How (from 1-5, with 1 being "poor" and 5 being "terrific") do you feel about the group? Poor, terrific, excellent.

Group building

Growth in relationship with God

(study, worship, prayer)

Outreach (evangelism and ministry)

Other

What kind of issues is your group working through?

What worries you about the group?

In what way is your group growing?

in love for each other

in love for God

in desire for and implementation of outreach. ${ }^{1}$

\section{$\begin{array}{lllll}1 & 2 & 3 & 4 & 5\end{array}$}

$\begin{array}{lllll}1 & 2 & 3 & 4 & 5\end{array}$

$\begin{array}{lllll}1 & 2 & 3 & 4 & 5\end{array}$

$\begin{array}{lllll}1 & 2 & 3 & 4 & 5\end{array}$

$\begin{array}{lllll}1 & 2 & 3 & 4 & 5\end{array}$

$\begin{array}{lllll}1 & 2 & 3 & 4 & 5\end{array}$

$\begin{array}{lllll}1 & 2 & 3 & 4 & 5\end{array}$

$\begin{array}{lllll}1 & 2 & 3 & 4 & 5\end{array}$

$\begin{array}{lllll}1 & 2 & 3 & 4 & 5\end{array}$

$\begin{array}{lllll}1 & 2 & 3 & 4 & 5\end{array}$

'Arnold, The Big Book on Small Groups, 259. 


\section{APPENDIX D}

SEVEN LESSON OUTLINES FOR SMALL

GROUP SEMINAR 


\section{SEVEN LESSON OUTLINES FOR SMALL \\ GROUP SEMINAR}

\section{Lesson: 1}

Day: Sunday

Topic. The Small Groups in the Old Testament.

Introduction:

Small Groups are God's ideal in the Old Testament. There are three persons in the Trinity, God the Father, the Holy Spirit, and Jesus Christ. God the Father did not create the world alone. God the Holy Spirit did not work alone. God Jesus Christ did not do it alone. The Trinity worked together as one at the creation of the world, everything that is in it, and man (Gen 1:1,26). The Trinity worked in a small group of three. Some other ways where we see God working in small groups.

Body of the Lesson:

1. Creation of the world (Gen 1:1)

2. Creation of man (Gen 1:26).

3. Choosing of Israel as a nation (Dan 7, 7-8).

4. Israelites divided into a small group (Gen 49).

5. Israelites divided into 12 tribes (Jos 13:22).

6, Israelites divided into house holds (Deut 6:22. Gen 50:8)

7. Israelites divided into families (Num 25:21-47).

8. Israelites organizational structure Num $10,50,100)$.

9. Sub-divisions of Canaan (Jos13:7, 8, 2; 3-27, 3:1-32).

10, Daniel and his three friends (Dan 2:40-3:29).

\section{Conclusion:}

God does not work alone. God works in small groups. God is a small group of three persons. Following God's ideal in the Old Testament will enable the church to succeed in all its programs. God created the world as a group. He picked on the nation of Israel and demonstrated how to utilize small groups in organizing and governing of nations. God assures His followers that He listens and answers small group prayers (Dan $2: 40-3: 1-32)$.

Day: Monday

Lesson: 2

Topic: Small Groups in the New Testament

Introduction:

A small group is God's ideal in the New Testament. Jesus Christ, in His ministry, did not work alone. If $\mathrm{He}$ had wanted to $\mathrm{He}$ could have worked alone, but $\mathrm{He}$ chose to work with others. Jesus wanted to work with human beings to reach people, heal the sick 
and comfort the disheartened in Israel. Jesus worked in a small group of disciples in His travels, teaching, and when He made pronouncements.

Body of the Lesson:

1. Jesus organized a small group of 12 disciples (Mark 1:16-20; John 13:1-17; Luke 6: 12-16).

2. He chose a small group of twelve disciples to work with Him (Mark 1:16-21; Luke 4: 3-14).

3. He often retired to be with a small group of 12 after addressing a crowd of people (Matt 5:12).

4. He taught the small group of disciples how to witness to a ruler to in His encounter with Nicodemus (John 3:4-49).

5. He taught a small group of twelve disciples how to witness to a Samaritan woman (John 4:4-36).

6. He taught about salvation to a small group of disciples (John 6:44).

7. The first Lord's Supper was conducted in a small group (John 10:1-17).

8. Jesus taught about love to a small group of twelve disciples (John 15:9-17).

9. Jesus taught about prayer to a small groups of twelve disciples (John 17:20-26; Acts $12: 1-17)$.

10.Jesus traveled with a small group of twelve disciples (Luke 16:11-15).

11. Jesus went to the Garden of Gethsemane with a small group of twelve disciples (Mark 14:32).

12. Jesus bade farewell to His disciples at His resurrection (Mark 16:9-14).

13. Jesus bade farewell to His disciples at His ascension (Acts 1:4-10).

14. Jesus gave the Great Commission to witness to the whole world to a small group of twelve disciples (Mark 19:19-20).

15. Jesus announced His second coming to the small group of disciples (Acts 1:8-9; John 14:1-4).

Conclusion:

Jesus shared His work with a small group of twelve disciples. He taught, conducted the first Lord's Supper, promised to come the second time, etc., with His small group. To Jesus, the most effective way to reach people was through the small group. Small groups worked for Jesus, small groups will work well in His church, small groups will work well today.

Day: Tuesday

Lesson: 3

Topic: Small Groups in the Early Church.

Introduction:

Small groups is God's ideal in the times of the twelve apostles and early church. The apostles were commissioned to spread the gospel to the Jews and Gentiles. The disciples did not work alone. They organized their witnessing to Jews and Gentiles in 
small groups. The results were tremendous. Many people were baptized and the church grew very fast. It grew so fast that even the Roman government leaders embraced it. For example, Constantine, the Roman Emperor.

\section{Body of the Lesson:}

1. Apostles met in small groups for the breaking of bread (Acts 5:46).

2. Apostles met in small groups in houses for prayer and worship (Acts 12:12

3. Paul, in his missionary journeys, met believers in small groups in houses (Acts 16:

11).

4. Paul sent letters of greetings to house small groups in Nymphas (Col 4:15) and Rome 16:50).

5. The small groups in the Middle Ages:

1) St. Francis of Assisi

2) Anabaptists

3) Hutterites of Germany

4) George Fox

5) Ellen G. White

a). To reach the unbelievers

b). To encourage one another

c). To nurture old and new members

d). To find unity

e). To intercede for one another in prayer

f). To study the Bible

g). To give testimonies

h). To show love

i). To present Christ to families

j). To labor in the church vicinity

k) To enable every church member to do his/her duty

l) Social meetings

m) To encourage them to preach less.

Conclusion:

The apostles continued to work in small groups as they went about preaching the Gospel. Paul, in particular, sent greetings to small house groups in Nymphas. Several groups and individuals formed small groups in the Middle Ages, for example, groups of people like Anabaptists and Hutterites, and individuals, such as St. Francis of Assisi, Ellen G. White, and George Fox. 
Day: Wednesday

Lesson: 4.

Topic: Small Groups is God's Ideal for Assimilation of New Members

Introduction:

A small group is God's ideal for assimilation of new members. New members are easily assimilated in a small group rather than in a big gathering of people. New members start to make new friends. They have lots of questions to ask, but they cannot do so easily in a large congregation. Some of the new members are shy and will not speak out. Some new members have family problems they cannot speak about in public. They would like to speak in confidence to a marriage counselor. A small group is ideal for these members to speak openly and freely.

Body of the Lesson:

1. Assimilation means "bringing into conformity, absorb or incorporate."1

2. Churches to conduct orientation of new members about the church structure, hierarchy and ordinances, such as, baptism, Lord's supper, church board, business meeting, etc.

3. The church to evaluate new members progress in their attendance, Bible studies, etc.

4. Encourage old members to live by example in their dealings with new members. They should not act as policemen to new members.

5. Encourage every church to form a forum to monitor new members and to keep a pool of new members in their churches.

6. Encourage the church to train and equip new members in order to absorb them into service.

7. Encourage churches to welcome new members in their churches, provide meals, joining clubs and small groups.

8. Encouraging churches to engage a Christian counselor to counsel old and new members

9. Members to socialize with new members at events like, New Year, Christmas, wedding parties, Independence Day, etc.

10. Encourage churches to old members to build long-lasting relationships with new members.

11. Encourage churches to train and equip new members for service as soon as possible and to provide safe environment for them by loving, caring, and sympathizing with them.

Conclusion:

Assimilation of new members will encourage them to stay on in the church. New members should feel welcomed in the church. They should also be trained and equipped for service. When new members are in trouble, they should be encouraged to consult a Christian counselor. Old members of the church should build long-lasting relationships

${ }^{4}$ Lesley Brown, 131-132. 
with new members. The old members should also provide a safe environment for new members by loving, caring for, and sympathizing with them.

Day: Thursday

Lesson: 5

Topic: A Small Groups is God's Ideal for Serving Those in Need

Introduction:

Small groups is God's ideal for service. God wants us to serve one another. Jesus came to set an example to follow. He came to seek and serve the lost. Jesus' followers are to emulate His example. Christians are to love and serve one another (John 13:34).

A: Serving Those in Need

1. Jesus came to seek and serve (Mark 10:45).

2. Each one of us to use our gifts to serve others (1 Peter 4:10).

3. We are cleansed of our sins to serve God (Heb 9:14).

4. We are to serve the Lord with gladness (Ps 100:2).

5. We serve God with obedience (Deut 13:4).

6. God loved us while we were yet sinners (Rom 5:8).

7. We are to serve God faithfully (1 Samuel 12:24).

8. God gave us His Son (John 3:16).

9. Serve others because of love (2 Cor 5:14-15; Mark 12:28-31; Gal 5:13).

10. All Christians are gifted to serve others (1 Cor12:4, 6-11, 27-31; Rom 12:4-8; 1 Cor 12:5; Eph 4:7-13; 1 Peter 4:11).

11. Christians are to care for one another (Gal 5:13).

12. Jesus commands His followers to love one another (John 13:34).

13. The works of love include: praying for one another (James 5:18), not telling lies (Col 3:9), humility (1 Peter 5:5), not complaining (James 5:9), encouraging one another (1Thess 5:1-11), regarding others more than ourselves (Phil 2:3).

B: Examples of people and their needs

1. The sick (Mark 25:45) need pastoral visits, prayers, medicine, hungry, sick, strangers, poor, etc.

2. Poor need food, clothes, blankets, running water in homes, building materials,

3. The widowers need comfort, food, clothes, shelter, prayers, visits by the pastor and church members, babysitter.

4. The family of the deceased need comfort, counselors, church member visits, comfort during the period of the funeral.

5. Those in prisons need: visits from church members/family, envelopes, papers, soap, food prepared by family members.

6. The poor need shirts, pants, dresses, shoes, jackets, blankets, sheets, pillows, mattresses.

7. The strangers need food, direction, and lodging place.

8. The falsely accused of witchcraft need security, and shelter. 
9. Abandoned and street kids need food, reconciliation and shelter.

10 Seniors need care, food, money, etc.

11. Refugees need church services, Bibles, hymnals, prayers for family members in Congo.

12. Unemployed new members need jobs, training, allocation of land, harvest season, cooperatives, etc.

13. The disabled new members need wheel chairs, training, medication, artificial limbs, lectures on the evils of war.

14. Those who are hurting need a counselor, money, a comforter, etc.

Conclusion:

Small group members are to serve those new members who are sick, poor, widows, widowers, bereaved, prisoners, strangers, refugees, disabled, war veterans, seniors, street kids, etc. New members needs includes: food, shelter, money, Bibles, medication, counselors, training, pastoral visit, care, etc. When these people's needs are taken care of, they will not leave the church through the back door.

Day: Friday

Lesson: 6

Topic: Small Groups Ideal for Spiritual Nurturing Introduction :

A small group is God's ideal for nurturing. A newborn baby needs milk to grow. Just like a baby, a newly baptized Christian needs to be nurtured to grow spiritually. $\mathrm{He}$ or she needs to study the Bible. A newly baptized Christian needs to pray to be in touch with God. The baptismal rite does not make one a fully grown Christian. It is only a sign that one has been born again into the Kingdom of God. The Bible tells us that "It is written, Man shall not live by bread alone, but by every word that proceedeth out of the mouth of God (Matt 4:4, AKJV).

Body of the Lesson:

1. Jesus taught His disciples to feed His sheep (John 21:15,17).

2. Jesus taught that man shall not live by bread alone (Matt $4: 4$ ).

3. Praying always is part of the nurturing process (1 Thess 5:17; Luke 21:36).

4. Studying the word of God is part of the nurturing process (2 Tim 2:15;3:13-17).

5. The Bible is sharper than a two-edged sword (Heb 4:12).

6. The Bible is profitable for doctrine (2 Tim 3:16).

7. Word of God is power unto salvation to one who believes (Rom 1:16).

8. Promises of God (Ps 119:103; Acts 1:8; Rev 22:7, 20).

9. Caring for the body is part of the nurturing process (1 Tim 6:19-20; 1 Cor 13; Lifestyle Phil 4:8-9; Rom 14:1-13).

10. Mature Christians (Phil 4:12-13).

a) New Christian make new friends (Mark 16:15-16; Matt 5:13, 14).

b) Identify gifts 
c) Lay Christian foundation

d) Encourage Bible study

e) Fellowship (1 John 1:7; Acts 2:42; 1 Cor 1:9; Gal 2:9).

Conclusion:

Newly baptized to be nurtured by the local church. It is not a one-time thing. It is a work of a lifetime. Old members need to nurture new members by teaching them the doctrines and ordinances of the church. They should teach them how to live by example. It is not an easy road. It is the work of a lifetime.

Day: Saturday

Time: 14 hours to 16 hours

Lesson: 7

Topic: Small Group is Ideal for Training in Discipleship

Introduction:

A disciple is "a fully committed follower of Christ ... an apprentice learning from his teacher by observing and practice. And as part of our learning and growing experience, a disciple is committed to encourage others to join him." A small group is ideal for training for discipleship. Jesus has commanded His followers to make disciples (Mark 19:19-20). Everyone who believes in Christ is born to be a disciple. Jesus also wants all believers to be fishers of men.

Body of the Lesson:

1. Jesus told His followers to bear fruit (John 15:16).

2. Jesus commanded His followers to make disciples (Matt 28:19, 20).

3. Followers are a blessing to others (Acts 2:43-47).

4. Followers are qualified to teach others ( $2 \operatorname{Tim} 2: 2)$.

5. Small groups to be organized in evangelism.

6. Small groups to be organized geographically.

7. Primary sources of disciples, include: family members, friends, workmates, fellow students, etc.

8. Members of small groups to be assigned missionary territories.

9. The work of small groups to make the church members be involved in small groups.

10.Small groups to follow in their program the territorial assignment principle.

Conclusion:

Jesus commands every one of His followers to make disciples. A disciple is someone who is committed to the cause. Small groups are ideal for training each and every disciple to win souls.

Members of the small groups to be organized in soul winning ventures and assigned geographically in their territories.

${ }^{5} \operatorname{Cox}, 39$. 
Day: Saturday

Time: 19 hour-20 hours (7:00-8:00pm).

Lesson: 8

Topic: A Small Group is Ideal for Pastoral Care

Introduction:

A small group is God's ideal for pastoral care. God wants us to share the responsibility of looking after new members with the pastoral staff. There are few pastors in the North Zambia Field. According to official figures, there are only sixteen pastors to care for more than 85,000 members. If we are to divide the number of pastors into the total membership, we will see that each pastor on the average cares for 5, 312 members. This is too much for one person. So the work of looking after new and old members should be shared with the church members.

Body of the Lesson:

1. Why a shared pastoral care? To engage members, elder and member to join the pastor in providing care to new and old members. Pastoral care involves, "care giving and shepherding."3

2. Survey of the inner circle .

3. To help meet the needs of old and new members of the church.

4. To communicate information quickly to all members of the small group and of the church.

5. Enable the church to provide more specific forms of pastoral care by the pastoral staff.

B: Benefits of small group pastoral care:

1. Pastor will specialize in his or her work

2.Creation of caring small group members in the community

3. Providing care to new and old members in small groups

4. Primary care to new and old small group members

5. Mutual care to new and old members

6. Backup care to new and old members

7. Responding to crisis in and out in the community

8. Crisis care giving to new and old members

9. Other Situations and emergencies

10. Supporting new and old members

11. Counseling new and old members

12. Training leaders to provide pastoral care

Conclusion:

Small groups are ideal for providing pastoral care. The small group members can give care right on the spot because the members live close by their new members. When a problem arises within the locality the information is passed on immediately and the need requested is provided by fellow small group members or church members. Such

${ }^{6}$ Donahue, 153. 
needs include, but are not limited to, transport to the hospital for the sick, funeral message, fire, etc.

The samples of one-year master plans of the North Zambia Field, Mansa South Mission District, and Chakopo Church are listed on the following pages.

1. The One-Year Master Plan for the North Zambia Field 2008

2. Mansa South Mission District One-Year Master Plan 2008

3.Chakopo Seventh-day Adventist Church One-Year Master Plan 2008 


\begin{tabular}{|l|l|l|l|l|l|l|l|l|l|l|}
\hline District & Membership & FG & BG & OG & TG & SG & PG & CG & HG & CG \\
\hline Bangweulu & 6,373 & 25 & 40 & 21 & 30 & 47 & 60 & 28 & 36 & 59 \\
\hline Chinsali & 902 & 20 & 12 & 19 & 21 & 16 & 30 & 14 & 20 & 16 \\
\hline Chembe & 3,759 & 17 & 60 & 46 & 19 & 61 & 25 & 31 & 19 & 18 \\
\hline Chienge & 3,371 & 32 & 12 & 42 & 12 & 34 & 21 & 47 & 18 & 20 \\
\hline Ngumbo & 851 & 45 & 13 & 49 & 19 & 61 & 32 & 36 & 19 & 24 \\
\hline Isoka & 1,198 & 60 & 40 & 51 & 65 & 50 & 53 & 32 & 42 & 29 \\
\hline Kalungwish & 1,738 & 50 & 32 & 21 & 34 & 19 & 23 & 18 & 26 & 26 \\
\hline Kaputa & 2,476 & 37 & 18 & 19 & 29 & 37 & 28 & 19 & 24 & 25 \\
\hline Kasama & 3,553 & 42 & 21 & 27 & 31 & 22 & 23 & 14 & 19 & 18 \\
\hline Kawambwa & 2,733 & 31 & 19 & 29 & 23 & 29 & 27 & 32 & 16 & 15 \\
\hline Kazembe & 6,592 & 41 & 36 & 29 & 37 & 28 & 21 & 25 & 30 & 18 \\
\hline Luwingu & 3,533 & 32 & 21 & 24 & 23 & 31 & 19 & 13 & 23 & 21 \\
\hline Lwena & 2,711 & 41 & 23 & 19 & 21 & 27 & 24 & 14 & 26 & 31 \\
\hline Mansa N. & 2.673 & 30 & 14 & 29 & 32 & 16 & 19 & 21 & 23 & 25 \\
\hline Mansa S. & 6,278 & 127 & 142 & 133 & 132 & 115 & 131 & 115 & 112 & 95 \\
\hline Mbala & 3,307 & 21 & 18 & 16 & 27 & 19 & 17 & 19 & 37 & 19 \\
\hline Mpika & 2,981 & 26 & 14 & 17 & 19 & 26 & 14 & 17 & 25 & 20 \\
\hline Mpulungu & 5,376 & 27 & 32 & 28 & 31 & 27 & 19 & 24 & 31 & 21 \\
\hline Mporokoso & 2,531 & 24 & 35 & 18 & 21 & 31 & 21 & 27 & 21 & 25 \\
\hline Mwense & 6,923 & 29 & 42 & 27 & 34 & 52 & 32 & 26 & 32 & 21 \\
\hline Mweru & 5,200 & 41 & 36 & 32 & 28 & 42 & 23 & 19 & 32 & 19 \\
\hline Nakonde & 1,759 & 15 & 12 & 14 & 24 & 17 & 19 & 25 & 15 & 16 \\
\hline Nchelenge & 5,089 & 23 & 31 & 16 & 41 & 24 & 26 & 17 & 20 & 15 \\
\hline Senga Hill & 2,177 & 16 & 12 & 14 & 20 & 17 & 15 & 13 & 17 & 12 \\
\hline Totals & 82,833 & 754 & 811 & 740 & 689 & 648 & 727 & 651 & 641 & 608 \\
\hline
\end{tabular}




\begin{tabular}{|l|l|l|l|l|l|l|l|l|l|l|}
\hline Church & $\begin{array}{l}\text { Membershi } \\
\mathrm{p}\end{array}$ & FG & BG & $\begin{array}{l}\text { O } \\
\text { G }\end{array}$ & TG & SG & PG & CG & H G & CG \\
\hline Chakopo & 315 & 4 & 15 & 12 & 9 & 8 & 7 & 6 & 5 & 4 \\
\hline Chinengwa & 70 & 5 & 9 & 7 & 5 & 4 & 9 & 8 & 5 & 3 \\
\hline Chilaka & 62 & 7 & 5 & 4 & 3 & 6 & 8 & 5 & 7 & 2 \\
\hline Fair Haven & 92 & 4 & 3 & 4 & 3 & 5 & 7 & 3 & 4 & 2 \\
\hline Fipanda & 45 & 3 & 2 & 3 & 4 & 2 & 5 & 4 & 3 & 4 \\
\hline Kaole & 257 & 9 & 5 & 8 & 9 & 8 & 7 & 9 & 4 & 5 \\
\hline Lombanya & 206 & 10 & 12 & 6 & 7 & 6 & 9 & 7 & 5 & 4 \\
\hline Loshi & 169 & 9 & 7 & 4 & 5 & 4 & 7 & 6 & 7 & 5 \\
\hline Mabumba & 173 & 8 & 6 & 7 & 6 & 5 & 4 & 6 & 4 & 3 \\
\hline Mansa Central & 298 & 9 & 7 & 8 & 7 & 4 & 9 & 7 & 5 & 4 \\
\hline $\begin{array}{l}\text { Mansa } \\
\text { Riverside }\end{array}$ & 154 & 8 & 5 & 9 & 7 & 6 & 8 & 9 & 8 & 7 \\
\hline Mikula & 68 & 6 & 6 & 8 & 9 & 5 & 7 & 6 & 9 & 9 \\
\hline Mpandika & 126 & 9 & 7 & 9 & 9 & 4 & 6 & 4 & 6 & 7 \\
\hline $\begin{array}{l}\text { Muchinka } \\
\text { Central }\end{array}$ & 101 & 5 & 6 & 7 & 6 & 7 & 5 & 7 & 8 & 8 \\
\hline $\begin{array}{l}\text { Muchinka } \\
\text { Main }\end{array}$ & 230 & 4 & 8 & 5 & 7 & 7 & 6 & 8 & 7 & 7 \\
\hline Mulumbi & 96 & 5 & 7 & 7 & 6 & 6 & 5 & 6 & 5 & 6 \\
\hline Mutende & 235 & 5 & 5 & 7 & 4 & 6 & 5 & 6 & 6 & 7 \\
\hline Muwanguni & 100 & 4 & 5 & 6 & 8 & 8 & 4 & 3 & 5 & 4 \\
\hline Namwandwe & 92 & 3 & 4 & 5 & 5 & 7 & 5 & 2 & 3 & 1 \\
\hline Nsonga & 264 & 6 & 6 & 7 & 8 & 3 & 5 & 6 & 4 & 2 \\
\hline West Gate & 133 & 4 & 6 & 7 & 5 & 4 & 3 & 3 & 2 & 1 \\
\hline Totals & 6,278 & 14 & 133 & 13 & 11 & 13 & 115 & 112 & 112 & 94 \\
\hline
\end{tabular}




\begin{tabular}{|l|l|l|l|l|l|l|l|l|l|l|}
\hline Church & Membership & FG & BG & OG & TG & SG & PG & CG & H C & CE \\
\hline Chakopo & 3154 & 15 & 12 & 9 & 8 & 7 & 6 & 5 & 4 & 4 \\
\hline
\end{tabular}
ABBREVIATIONS
FG-Fellowship Small Groups
BG-Bible Study Small Group
OG-Outreach Small Group
TG-Task/Ministry Small Group
SG-Support Small Group
PG-Prayer Small Group
CG-Covenant Small Group
HC-House Church
CE-Cell 
APPENDIX E

ORGANIZATIONAL CHART 


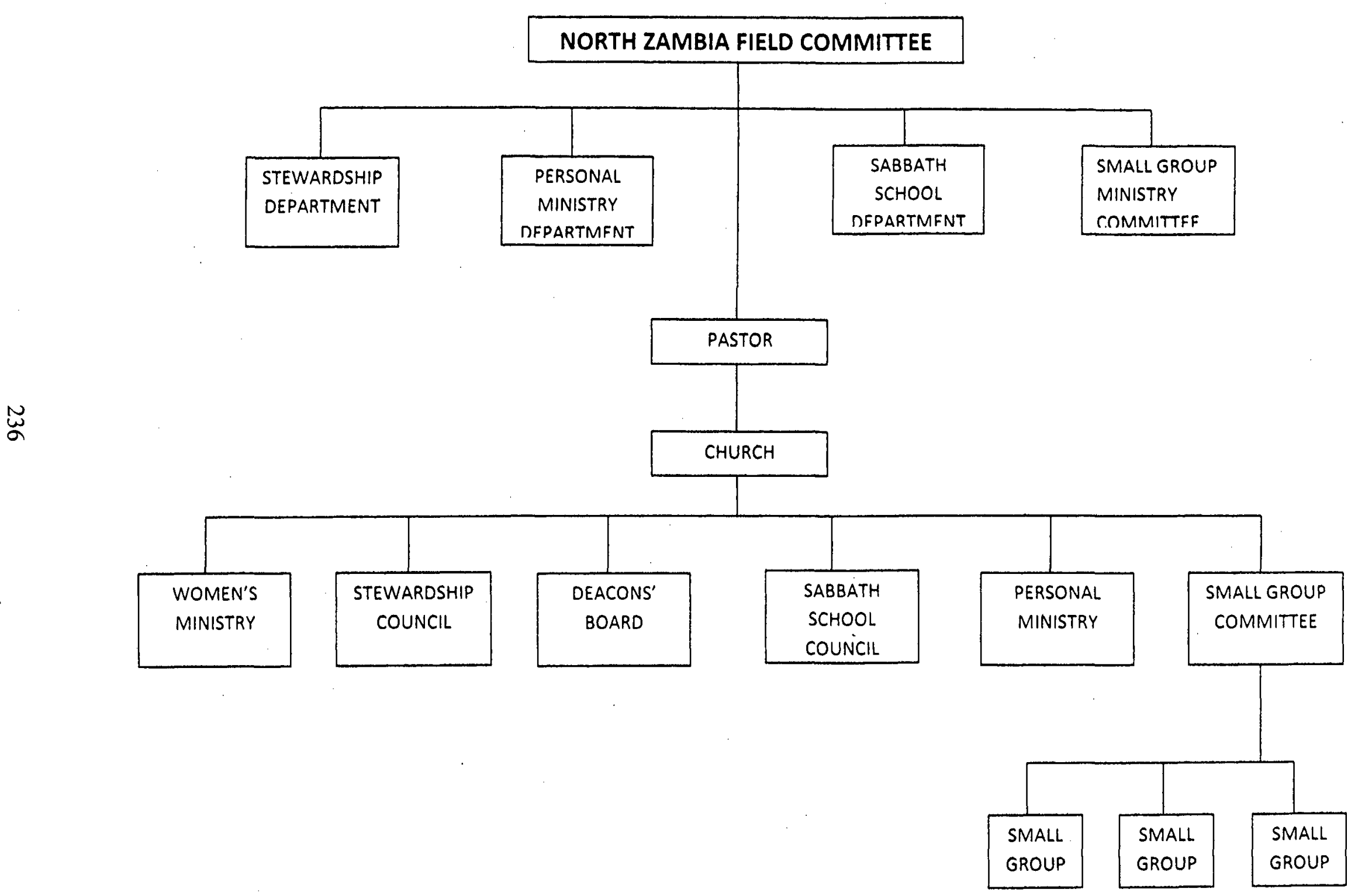


APPENDIX F

MAP OF ZAMBIA 
Map of Zambia: The North Zambia Field is Made up of Luapula and Northern Provinces

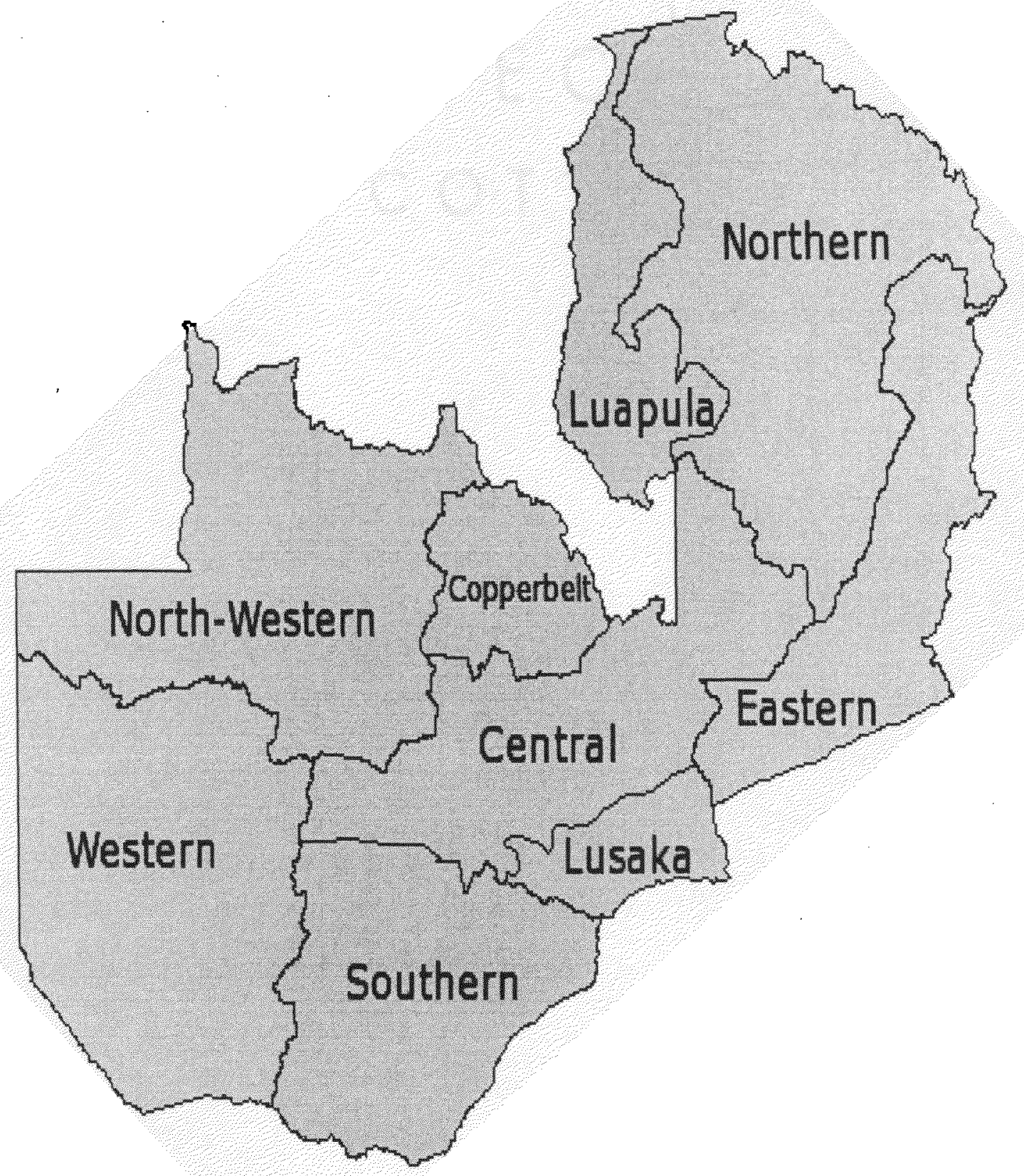

Source: http://www.mapofzambiaprovinces (accessed August 20, 2006) 


\section{BIBLIOGRAPHY}




\section{BIBLIOGRAPHY}

Andrew, Robert. A History of the Bemba. Madison, WI: University of Wisconsin, 1971.

Arnold, Jeffrey. The Big Book on Small Groups. Rev. ed. Downers Grove, IL: InterVarsity Press, 2004.

Arnold, Jeffrey, and Herb Miller. Starting Small Groups: Building Communities That Matter. Leadership Insight Series. Nashville: Abingdon Press, 1997.

Baker, Steve, Judy Johnson, and Bob Malone. Good Things Come in Small Groups: The Dynamics of Good Group Life. Downers Grove, IL: InterVarsity Press, 1995.

Bliss, Annie M., and J. A. Rigg. Zambia: World Bibliography Series. Vol. 51. Oxford, England: Clio Press, 1983.

Brown, Lesley. The New Shorter Dictionary on Historical Principles. Vol. 1. Oxford, UK: Clarendon Press, 1993.

Bunch, Cindy. Small Group Idea Book: Resources to Enrich Community, Worship, Prayer, Bible Study, Outreach. Rev., expanded ed. Downers Grove, IL: InterVarsity Press, 2003.

Butler, Gillian, and Freda McManus. Psychology: A Very Short Introduction. New York: Oxford University Press, 1998.

Carvey, Brian. Bemba Land Church. New York: E. J. Brill, 1994.

Caslow, E. Daniel. Discipling New Member Ministry. Mountain View, CA: Pacific Press Publishing Association, 1982.

Cerna, Angel Miguel. The Power of Small Groups in the Church. New Park, CA: El Camino Publishing, 1991.

Child, Dennis. Psychology and the Teacher. New York: Continuum, 2004. 
Clark, E. Robert, Lin Johnson, and Allyn K. Sloat. Christian Education Foundations for the Future. Chicago: Moody Press, 1991.

Cole, Neil. Cultivating a Life for God: Multiplying Through Life Transforming Groups. Carol Stream, IL: ChurchSmart Resources, 1999.

Coleman, Lyman. Serendipity Training Manual for Groups. Littleton, CO: Serendipity House, 1989.

Cloud, Henry, and John Sims Townsend. Making Small Groups Work: What Every Small Group Leader Needs to Know. Grand Rapids. MI: Zondervan Publishing House, 2003.

Cornelius, M. Matandiko. Seventh-day Adventism in Zambia. Lusaka, Zambia: Zambia Adventist Press, 2003.

Cox, David. Think Big Think Small Groups: A Guide to Understanding and Developing Small Group Ministry in Adventist Churches. Watford, Herts, England: South England Conference of Seventh-day Adventists, Dept. of Personal Ministries, 1998.

Donahue, Bill. Leading Life-Changing Small Groups. Grand Rapids, MI: Zondervan Pub. House, 1996.

Donahue, Bill, and Russ Robinson. Building a Church of Small Groups: A Place Where Nobody Stands Alone. Barrington, IL: Willow Creek Association, 2001. . The Seven Deadly Sins of Small Group Ministry. A Troubleshooting Guide for Church Leaders. Grand Rapids, MI: Zondervan Pub. House, 2002.

Donahue, Bill, and Willow Creek Community Church. The Willow Creek Guide to Leading Life-Changing Small Groups. Grand Rapids, MI: Zondervan Pub. House, 1996.

Dudley, Roger L., and Des Cummings Jr., Adventures in Church Growth Hagerstown, MD: Review and Herald, 1983.

Egli, Jim. Upward, Inward, Outward, Forward: Improving the 4 Dynamics of Your Cell Group. Rev. ed. Houston, TX: Cell Group Resources, 2000.

Elliot, Rodney D., and Don H. Shamblin. Society in Transition: A Humanistic Introduction to Sociology. Englewood Cliffs, NJ: Prentice Hall, 1992. 
Engleberg, Isa N., and Dianna Wynn. Working in Groups. Communication Principles and Strategies. 2nd ed. Boston: Houghton Mifflin, 2000.

Eriksen, Hylland Thomas. Small Places Large Issues: An Introduction to Social and Cultural Anthropology. 2nd ed. Setering, VA: Plato Press, 2000.

Ferrante, Joan. Sociology: Global Perspective. Kentucky: Northern Kentucky University, Wadsworth Publishing Company, 1992.

Fields, Doug. Purpose Driven Youth Ministry: 9 Essential Foundations for Healthy Growth. Grand Rapids, MI: Zondervan Publishing House, 1998.

Fowler, H. W., and H. G. Fowler. The Concise Oxford Dictionary of Current English, $8^{\text {th }}$ ed. Oxford: Clarendon Press, 1992.

Fraizer, Donald. Winning a Primitive People. Westport, CT: Negro College University, 1970.

Gangel, O. Kenneth, and James C. Wilhoit. The Christian Educator's Handbook on Adult Education. Wheaton, IL: Victor Books/SP Moody Press, 1991.

General Conference of Seventh-day Adventists. Discipling New Members. Washington, DC: Department of Women Ministries, 2005.

. North Zambia Field of the Seventh-day Adventist Church Statistics, 1993-2003. General Conference of Seventh-day Adventists Website List (February 25, 2005).

George, Carl. Prepare Your Church for the Future. Grand Rapids. MI: Revell, 1992, 31. Quoted in David Slamp, Care Rings Sunday School and Small Groups. Wichita, KS: Vessel Press, 2004.

Gibbs, Jeanne. TRIBES: A New Way of Learning and Being Together. Windsor, CA: Center Source System, 2001.

Giddings, Franklin. Cultural Anthropology. Grand Rapids, MI: Baker Book House, 1983.

Goodman, Norman. Introduction to Sociology. New York: Harper Collins Publishers, 1992.

Gorman, Julie. Community That Is Christian. 2nd ed. Grand Rapids, MI: Baker Books, 2002. 
Gouldsbury, Gullen, and Herbert Sheane. The Great Plateau of Northern Rhodesia. New York: Negro College University, 1969.

Haggard, Ted. Dog Training, Fish Flying and Sharing Church in the $21^{\text {st }}$ Century. Nashville: Thomas Nelson Publishers, 2002.

Hestenes, Roberta. Using the Bible in Groups. Philadelphia, PA: The Westminister Press, 1983.

Hiebert, G. Paul. Cultural Anthropology. Grand Rapids, MI: Baker House, 1983.

"History of Church Activities in Zambia." http://www.en.wikipedia.org/wiki/History-ofChurch-Activities-in Zambia (accessed March 24, 2006).

Hoch, E. Bemba, Bemba-English, English-Bemba: Hippocrene Concise Dictionary. New York: Hippocrene Books, 1998. . Bemba Pocket Dictionary. Ndola, Zambia: Zambia Mission Press, 1992.

Hurston, Karen. Breakthrough Cell Groups: How One American Church Reaches People for Christ through Creative Small Groups. Houston, TX: Touch Publications, 2001.

James, Donald. Cell-Based Ministry. Berrien Springs, MI: Andrews University Press, 2005.

Johnson, Kurt W. Small Groups for the End Time: A Practical Guide for the TwentyFirst Century. Hagerstown, MD: Review and Herald, 1997.

Kottak, Phillip Conrad. Cultural Anthropology. 8th ed. New York: McGraw Hill, 2000.

Landrum, Eric, Stephen Davis, and Teresa Landrum. The Psychology Major Career Option and Strategies for Success. Upper Saddle River, NJ: Prentice Hall, 2000.

Languages of Zambia for 2000-2001. Http://www.enthnologue.com (accessed November $16,2006)$.

Leslie, Robert. Sharing Groups in the Church: An Invitation to Involvement. Nashville: Abington Press, 1971.

Mack, Michael C. The Synergy Church: A Strategy Integrating Small Groups and Sunday School. Grand Rapids, MI: Baker Books, 1996. 
Mallison, John. Growing Chrisitians in Small Groups. Homebush, West, NSW, Australia: Scripture Union Books Anazea Publishers, 1993.

Malloy, Rock J. G-12 Group of Twelve: Launching Your Ministry into Explosive Growth. Texas City, TX: Impact Production Faith Ministries, 2002.

Marlowe, Leigh. Social Psychology: An Interdisciplinary Approach in Human Behavior. Boston: Holbrook, 1975.

Matandiko, Cornelius M. Seventh-day Adventism in Zambia. Lusaka, Zambia: Zambia Adventist Press, 2003.

McBride, Neal. How to Have Great Small Group Meetings: Dozens of Ideas You Can Use Right Now. Colorado Springs, CO: NavPress, 1997. . How to Lead Small Groups Colorado Springs, CO: NavPress, 1998. . Real Small Groups Don't Just Happen, Nurturing Relationships in Your Small Group. Colorado Springs, CO: NavPress, 1998.

Neighbour, W. Ralph, Jr. Where Do We Go From Here? A Guide for the Cell Group Church. Houston, TX: Touch Publications, 1990.

Neighbour, Randall. Answers to Your Cell Group Questions. Cell Leader Enrichment Series. Houston, TX: Touch Publications, 2000.

Nigel, Rupport, and Joanna Overing. Social and Cultural Anthropology: Key Concepts. New York: Routledge, 2000.

North America Division of the Seventh-day Adventist Church. Responsibilities in the Local Church. Lincoln, NE: AdventSource, 2002.

Obayashi, Hiroshi. Death After Life: Perspective of World Religions. New York: Greenwood, 1992.

O’Neil, Philip. "People Mixing." http://www.peoplemixing.com (accessed May 11, 2005).

Partunder, C. Corporative Learning Center. "What is Corperative Learning?" The University of Minesota. http:www.corporation.org (accessed May 11, 2005).

Plueddemann, Jim, and Carol Plueddemann. Pilgrim in Progress. Wheaton, IL: Harold Shaw, 1990. 
Pollard, Andrew, and Sarah Tann. Reflective Teaching in Primary Schools: A Handbook for Class. 2nd ed. Witshire, England: Redwood Books, 1993.

Rapport Nigel, and Joanna Overing. Social and Cultural Anthropology: Key Concepts. New York: Routledge, 2000.

Richards, Lawrence O. A New Face for the Church. Grand Rapids, MI: Zondervan Publishing House, 1991.

Robertson, Ian. Sociology. 3rd ed. New York: Worth Publishers, 1988.

Rose, Walton H. "The Use of Small Groups as an Element of Discipleship in the Fairhaven, Flint, Michigan, Seventh-day Adventist Church." D.Min. disssertation, Andrews University, 1996.

Schaefer, Richard T. Sociology: A Brief Introduction. 5th ed. New York: MacGraw Hill Publishers, 2004.

Seventh-day Adventist Bible Commentary. Edited by F. D. Nichol. Washington DC: Review and Herald Publishing Association, 1980.

Seventh-day Adventist Church Encyclopedia. 1976 ed. S.v. "Bemba," "Chimpempe," "Musofu," "Rusangu."

Seventh-day Adventist Church Website. North Zambia Field. http://www.adventist statistics.org/view (accessed February 24, 2006).

Shaw, Haydn. "Small Groups: The Shape of Things to Come." Visionary 6 (1991): 4.

Slamp, David. Care-Rings: Sunday School and Small Groups. Wichita, KS: Vessel Press, 2004.

Smelser, Neil J. Sociology. Englewood Cliffs, NJ: Prentice Hall, 1981.

Stoner, J. A. Sociology, 3rd ed. New York: Worth Publishers, 1988.

Swartz, Christian. Natural Church Development: A Guide to Eight Essentials Qualities of Healthy Churches. St. Charles, IL: Church Resources, 2000.

Tetz, Myrna, and Gary L. Hopkins. We Can Keep Them in the Church: How to Love Our Children So They Won't Leave. Nampa, ID: Pacific Press Publishing Association, 2004. 
Thomson, Ronald Charles Lloyd. "History of the Growth and Development of the Seventh-day Adventist Church in Southern Africa, 1920-1960." D.Min. dissertation, Andrews University, 1996.

TRIBES: A New Way of Learning and Being Together, Reaching All Students: Tribe Learning Community. http://wwwtribes.com/reaching_all_students.htm (accessed March 21 2005).

TRIBES: A New Way of Learning and Being Together, "Announcements." http://www.tribes,com/announcements_new_material.him (accessed March 21, 2005).

Venes, Donald. Taber's Cyclopedic Medical Dictionary. Philadelphia: F. A. Davis Company, 1997.

Ware, Corinne. Connecting to God: Nurturing Spirituality through Small Groups. Bethesda, MD: Alban Institute, 1997.

Weber, L. Ann. Introduction to Psychology. New York: Harper Perennial Publisher, 1991.

Wendland, E. H. Of Other Gods and Other Spirits. Milwaukee, WI: Northwestern, 1977.

Werner, Douglass. "Some Development in Bemba Religious History." Journal of Religion in Africa 4, no. 1 (1971): 21.

White, Ellen G. Advent Review and Sabbath Herald, 8 January 1895.

.Christian Service. Washington, DC: Home Department of the General Conference of the Seventh-day Adventist Church, 1947.

. Desire of Ages. Mountain View, CA: Pacific Press Publishing Association, 1940.

. Evangelism. Mountain View, CA: Pacific Press Publishing Association, 1948.

Gospel Workers. Washington, DC: Review and Herald Publishing Association, 1915.

. Ministry of Healing. Mountain View, CA: Pacific Press Publishing Association, 1948. 
. MS32, 1884, Center for Adventist Research, Andrews University, Berrien Springs, MI.

. Review and Herald, September 29, 1891.

. Steps to Christ. Mountain View, CA: Pacific Press Association, 1948.

. Testimonies for the Church. 9 Vols. Mountain View, CA: Pacific Press

Publishing Association, 1948.

.Welfare Ministry. Washington, DC: Review and Herald Publishing Association, 1915.

Wright, J. "South African Division." Review and Herald, May 29, 1941.

Wuthnow, Robert. "How Small Groups Are Transforming Our Lives." Christianity Today, February 1994, 2, http://webinfotrack.galegroup.com/itw/informark684/ 805/64860609w4/purl=rcl_GRGM (accessed 23 March 2005). Quoted in Donald James, Cell-Based Ministry. Berrien Springs, MI: Andrews University Press, 2005.

. Sharing the Journey: Support Groups and America's Quest for Community. New York: The Free Press, 1004.

Zambia Field Minutes. January 5-10, 1980, Action Number 324. 
VITA 
Name: Wellington Supuni Chapi

Date of Birth: March 25, 1947

Place of Birth: Lwela Mission, Mansa

Nationality: Zambian

\section{EDUCATION}

1967 - Certificate in Education, Malcom Moffat Teacher Training College, Zambia 1978 - Ministerial Training Course Diploma, Rusangu Ministerial School, Monze 1991 - Bachelor of Arts in Theology, Solusi University, Zimbabwe 1999 - Masters in Religion, Balcock University, and Helderberg College, S. Africa. 2002 - Master of Divinity Equivalency, Andrews University Seventh-day Adventist Seminary

2008 - Doctor of Ministry, Andrews University Seventh-day Adventist Seminary

\section{WORK EXPERIENCE}

1968 - Primary Teacher, Chipungu School

1970 - Deputy Headmaster, Kaminsa Primary School

1978 - Pastor, Kitwe District, Copperbelt Zambia Field

1979 - Pastor, Kabwe District, Central Zambia Conference

1980 - Pastor, Lusaka District, Central Zambia Conference

1983 - Ordination, May 2, Lusaka, Zambia

1985 - Pastor, Ndola District, Copperbelt Zambia Field

1991 - Pastor, Luanshya District, Copperbelt Zambia Field

1998 - Pastor, Chelstone District, Lusaka

1992 - Ministerial Secretary/Lay Activities /Communication Director, Zambia Union Conference

1997 - Voice of Prophecy and Media Director, Zambia Union Conference

1999 - Ministerial Secretary and Stewardship Director, Central Zambia Conference

2000 - President, North Zambia Field

\section{INITIATIVES}

1997 Certificate in Camera Handling and Video Production, Lusaka, Zambia

2003-7 Member of Small Group: Pioneer Memorial Seventh-day Adventist Church, Berrien Springs, MI

2007 DeHaan Work Excellence Award, Andrews University 